Uirá Fernandes

O currículo na encruzilhada pós-moderna - um estudo de caso de uma escola pública paulistana

Universidade de São Paulo

Faculdade de Educação

2007 


\section{Uirá Fernandes}

\section{O currículo na encruzilhada pós-moderna - um estudo de caso de uma escola pública paulistana}

Dissertação apresentada ao programa de pós-graduação da Faculdade de Educação da Universidade de São Paulo, como requisito parcial à obtenção do título de Mestre em Educação, sob orientação da Profa. Dra. Maria Isabel de Almeida. Linha de Pesquisa: Didática, Teorias de Ensino e Práticas Escolares

Universidade de São Paulo

Faculdade de Educação 
Dedicatória

Dedico este trabalho ao mundo mexicano, e a todos que dele fizeram minha vida diferente. 


\section{Agradecimentos}

Gostaria de agradecer primeiramente à Escola Municipal que abriu suas portas para a realização desta pesquisa e que o fez de forma muito acolhedora e atenciosa. Agradeço em especial ao diretor, assistente de direção, às duas coordenadoras, ao grupo de professores, de agentes escolares e aos alunos dessa escola que não só tornaram viável este trabalho, como me fizeram admirar seu trabalho e esforço para melhorar o ensino público deste país.

Agradeço imensamente à minha orientadora Profa. Dra. Maria Isabel de Almeida que me apoiou em momentos importantes para a realização desta pesquisa e por sua enorme contribuição para que eu melhor pudesse realizar o meu trabalho e ir me tornando um pesquisador. Além disso, me considero privilegiado por estar próximo de uma professora preocupada com a ampla (e ampliação da) formação do pesquisador, seja pela abertura à participação no GEPEFE (Grupo de Estudos e de Pesquisa sobre Formação de Educadores) e no PAE (Programa de Aperfeiçoamento do Ensino), seja pela participação na pesquisa sobre Ciclos e pelo incentivo e possibilidade de participação do programa de intercâmbio acadêmico internacional oferecido pela Red de MacroUniversidades de América Latina y Caribe.

Por conseguinte, agradeço ao GEPEFE pela oportunidade singular de participar de um grupo de estudos e pesquisa capaz de proporcionar não só a reflexão sobre diversos temas da educação, como a formação de professores, a didática e a ciência pedagógica, como, sobretudo, pelo amadurecimento da condição de pesquisador neste país. Agradeço, assim, a todos os integrantes que fizeram e fazem parte deste grupo e que não só escutaram e receberam meus comentários, pensamentos e proposições, como, principalmente, criticaram, sugeriram mudanças, propuseram leituras, etc., sobre a minha pesquisa. Agradecimentos especiais aqui aos coordenadores Profa Dra. Selma Garrido Pimenta, Profa. Dra. Maria Isabel de Almeida e ao Prof. Dr. José Cerchi Fusari.

Agradeço à Faculdade de Educação da USP por seu apoio institucional e pela atmosfera acadêmica. Em especial à Secretaria de Pós-Graduação e a Comissão de PósGraduação, da qual fui representante discente no ano de 2005.

Agradeço aos dois professores que fizeram parte de minha banca qualificação, Profa. Dra. Selma Garrido Pimenta e Prof. Dr. Antonio Joaquim Severino, e de defesa a mesma Profa Selma e a Profa. Dra. Terezinha Rios, por sua disponibilidade, leitura e crítica ao trabalho. 
Agradeço ainda à bolsa de pesquisa outorgada pela Red de Macro Universidades de América Latina y Caribe y banco Santander e à Pró-Reitoria de Pós-Graduação da USP que tornou o recebimento da bolsa possível. Por consequiência, agradeço à Universidade Nacional Autônoma do México (UNAM), aos professores daquela instituição e em especial ao orientador Prof. Dr. Ernesto Gonzalez Enders, me acolheu muito bem e proporcionou debates interessantes para esta pesquisa.

Agradeço ainda à Representação Discente desta faculdade da qual fiz parte durante o ano de 2005, em especial ao grupo de colegas estudantes da Gestão Espaço Aberto, por contribuído para o fortalecimento da voz e participação dos estudantes dentro do mundo da política acadêmica e da instituição em particular.

Agradeço ao grande amigo chileno Andrés que, para além de nossa amizade, me ajudou a amadurecer intelectualmente, fruto de nossas inúmeras discussões sobre o universo teórico-prático da educação. Agradeço ainda sua escuta, seu incentivo em momentos difíceis e seus excelentes comentários nas leituras a respeito de meus escritos.

Agradeço à Emília, que sempre esteve ao meu lado, que foi paciente, compreensiva, incentivadora e sensível às minhas necessidades. Admiro sua admiração e agradeço seu apoio, sobretudo nas horas de grande confusão mental e crises intelectuais, além das longas horas de estudo. Especial agradecimento ao apoio dado no período em que estivemos distantes, por conta de minha estadia em solo mexicano.

Agradeço aos meus pais, Ernani e Giselle, por seu eterno incentivo aos meus estudos. À minha mãe por seu apoio afetivo e sua vibração em minhas conquistas e etapas ultrapassadas. A meu pai, por seu incentivo moral e importância em minha formação políticointelectual. Minhas queridas irmãs, Yara, Maíra, Rita e Nina, também merecem meu reconhecimento pois sempre, cada uma de uma forma, me apoiaram, me escutaram, me aturaram e me incentivaram.

Meus tios Rosana e Waldir também merecem meus agradecimentos, pois sempre foram pessoas fundamentais na minha formação ética e política, juntamente com meus pais. À Rosana, além de tudo, pela revisão de todo este texto, e ao Waldir pela viabilidade da pesquisa na escola.

Por fim, agradeço a dois grandes e eternos amigos, Tarso e Coré, me proporcionaram vivências, conversas, discussões e ensinamentos e, que com todos acima, me ajudam a ser quem sou hoje e a chegar ao fim desta etapa em minha vida. 


\section{Resumo}

O presente trabalho parte do debate posto pelo pensamento pós-moderno aos estatutos da modernidade e procura investigar sua relação com a teoria e prática educacional e mais especificamente escolar e com o campo do currículo. Buscou-se analisar como o pensamento, o discurso e a condição pósmoderno podem e/ou afetam o currículo e a vida da escola. Para isso, a pesquisa lançou mão de um estudo de caso de uma escola pública de Ensino Fundamental de forma a analisar as múltiplas dimensões da vida escolar e as ações, práticas e discursos dos diferentes integrantes da escola professores, alunos, direção, coordenação e agentes escolares. Buscou-se assim, refletir sobre como a escola e seu currículo se colocam diante do pensamento, discurso e condição pós-modernos, e como a posição pós-estruturalista pode "ler" os fenômenos do currículo escolar. Em termos de resultados da pesquisa procurou-se estar atento ao que dizia o campo, a escola, sem perder de vista quais debates travavam os diferentes matizes do pós-moderno em educação. O lema do "aprender a aprender", seja como ideologia do capitalismo atual, seja como forma discursiva dominante no cenário pedagógico contemporâneo, mostrou-se presente em práticas e discursos de diversos integrantes da escola. Em um segundo momento, refletiu-se sobre como o mundo do trabalho e a cidadania se interseccionam com o universo da escola e seu currículo. Analisou-se, assim, os desafios e avanços que esta escola tem conseguido para nela desenvolver e implementar uma cultura mais democrática em sua gestão e por procurar aproximar-se da comunidade, vinculando-se através da cultura, do esporte e do saber. Por outro lado, as barreiras sociais impostas às camadas pobres para a mobilidade e ascensão social - por meio do emprego, do acesso aos bens de consumo e da extensão da vida estudantil até a universidade - tornam ainda maiores na medida em que a escola está submetida à lógica neoliberal do Estado Mínimo, à maximização dos resultados com o mínimo de recursos financeiros, à desvalorização do professor e a uma pedagogia calcada no aprender a aprender. No terceiro momento, analisou-se as contribuições da perspectiva pós-estruturalista, sobretudo de linha foucaultiana, na compreensão do currículo escolar. Para isso, compreendeu-se o currículo como política cultural, como lugar de disputa por determinadas narrativas e pelo "direito" de se narrar o "outro". A abordagem destas questões referentes ao diálogo entre teoria e empiria, se guiou pela proposição de se situar criticamente em relação a pós-modernidade. Seja relevando seus aportes que enfrentam certos estatutos da modernidade e seus efeitos de dominação, como o universalismo e a neutralidade da razão e da ciência, as meta narrativas e a concepção de sujeito do conhecimento autocentrado presentes nas teorias (críticas) educacionais, seja pela necessidade de se apontar o risco de adesão aos ideais neoliberais do capitalismo atual através de práticas pedagógicas e políticas educacionais, o objetivo deste estudo foi refletir sobre possíveis interconexões e relações a respeito da teoria e prática educacionais com o pós-moderno quando se debruça sobre a escola e o currículo na atualidade. Este estudo se balizou, dentre outros autores, em Silva (1999, 1999b), Moreira (1994, 1997), Duarte (2001), Canário (1996), Foucault (2000) e Santos (1999).

Palavras-chave: Escola, modernidade, pós-modernidade, teoria e prática do currículo. 


\begin{abstract}
This work starts from the discussion presented by the post-modern thought before the rules of modernity and tries to investigate its relation with the educational theory and practice, and more specifically the school's and its curriculum field. I tried to analyze how the post-modern way of thinking, the discourse and the condition can and/or may affect the curriculum and school life. For this, the research has studied a primary public school to analyze the multiple dimensions in school life and the actions, practices and discourses of different school members - teachers, students, the principal, coordinators and school agents. Therefore, I aimed to reflect how the school and its curriculum are placed before the post-modern thought, discourse and conditions, and how the poststructural position can "read" the phenomena of the school's curriculum. According to the results of the research I tried to be aware of what the field and the school said, without losing track of what discussions were held between the different shades of the post-modern in education. The motto of "learning to learn", either as an ideology of the present capitalism, or as a dominant discursive form in the contemporary pedagogical scenario has showed itself to be present in practices and discourses by different school members. On a second moment, I reflected how the working world and the citizenship intertwine with the school universe and its curriculum. I analyzed, therefore, the challenges and the advances that this school has achieved to develop, to implement a more democratic culture by means of its direction and to get closer of the community, binding through culture, sport, and knowledge. On the other hand, the social barriers imposed to the poorer tracts of society to provide social mobility and ascension - though jobs, the access to consuming goods and the extension of student life up to college - have become even greater as long as school is submitted to the neo-liberal logic of the Minimal State, to the maximization of the results with the minimum financial resources, to the devaluation of teachers, and a pedagogy rooted in learning to learn. On a third moment, I analyzed the contributions of the post-structural perspective, mainly of the Foucault line, for the understanding of the school curriculum. For this, I understood the curriculum as a cultural policy, as a place for dispute of certain narratives and for the "right" to narrate the "other". The approach of these questions concerning the dialogue between the theory and the empirics was guided by the proposition of placing oneself critically before post-modernity. Either emphasizing its rapports that face certain rules of modernity and its dominating effects, like the universalism and the neutrality of reason and science, the discursive targets and the conception of the subject of self-centered knowledge present in the (critical) educational theories, or the need to point out the risk of adhering to the neo-liberal ideals of the present capitalism through pedagogical practices and educational policies, the object of this study was to reflect about some possible interconnections and relationships between the educational theory and practice and the post-modern when we focus on the school and its curriculum today. This study was based, among other authors, on Silva (1999, 1999b), Moreira (1994, 1997), Duarte (2001), Canário (1996), Foucault (2000) and Santos (1999).
\end{abstract}

Key-words: School, Modernity, Post-Modernity, theory and practice of the curriculum. 


\section{Sumário}

Introdução

Capítulo I - A contemporaneidade: a modernidade e o pensamento pós-moderno - os conceitos, o debate e as fronteiras teóricas

1. Caracterização do debate - contexto e conceitos

10

1.1 A modernidade e a crise

$1.2 \mathrm{O}$ debate contemporâneo da crítica da modernidade - definições, interpretações e controvérsias

1.3 A atmosfera da crise e a ordem cultural pós-modernista

1.4 Apontamentos preliminares - continuidades e rupturas

Capítulo II - Ideais pedagógicos modernos, história e sistema de ensino

1. Educação e escola no "projeto" da modernidade

2. Modernização, idéias pedagógicas e sistema de ensino na América Latina

3. Pensamento pedagógico brasileiro e modernização escolar

4. Pensamento educacional pós-modernista no debate sobre currículo

Capítulo III - Projeto político-pedagógico, currículo e cidadania - um estudo de caso em uma escola pública paulistana

1. Método - justificativa e procedimentos de trabalho

2. A escola - o campo e suas descobertas

2.1 A trajetória histórica da escola - rupturas e mudanças

2.2 Da estrutura escolar

2.3 Do projeto político-pedagógico

2.4 Da gestão escolar

2.5 Da relação escola, família e comunidade

2.6 Da relação com o conhecimento e a aprendizagem - professores, alunos e atividades (extras) curriculares

2.7 Do papel e sentido da escola na contemporaneidade para seus integrantes

Capítulo IV - O currículo da escola na encruzilhada pós-moderna

1. O campo do currículo - uma revisão político-epistemológica 91

2. O currículo da escola na encruzilhada pós-moderna 96

2.1 O lema "aprender a aprender" no currículo escolar contemporâneo $\quad \mathbf{1 0 0}$

$2.2 \mathrm{O}$ currículo entre a cidadania e o mundo do trabalho $\mathbf{1 0 6}$

2.3 A perspectiva pós-estruturalista e o currículo como política cultural $\mathbf{1 1 2}$ 


\section{LISTA DE SIGLAS}

CP Coordenador pedagógico

EMEI Escola Municipal de Ensino Infantil

EMEF Escola Municipal de Ensino Fundamental

JEI Jornada Especial Integral

ONG Organização Não Governamental

PPP Projeto político-pedagógico 


\begin{tabular}{|c|c|}
\hline \multicolumn{2}{|c|}{$\begin{array}{c}\text { Uirá } \\
\text { Fernandes }\end{array}$} \\
\hline 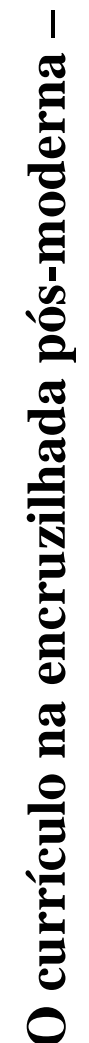 & 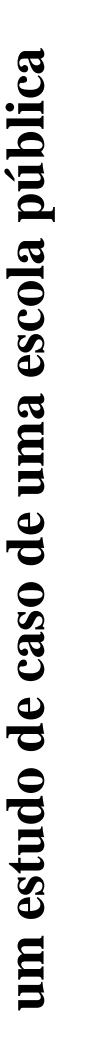 \\
\hline & $\begin{array}{l}\text { SP } \\
97\end{array}$ \\
\hline
\end{tabular}




\section{Introdução}

O interesse pela realização desta pesquisa nasceu no bojo de inquietações intelectuais que percorreram o período de minha graduação. Como bacharel e licenciado em Ciências Sociais pela USP e desde o momento em que me vi diante dos primeiros estudos na área da Educação na Licenciatura, chamou-me a atenção a dicotomia teoria e prática entre Ciências Sociais e Educação.

Sentia-me, primeiramente, desapontado com a "distância" que o bacharelado me deixara diante do que ocorre na prática social cotidiana. Agregado a isso, a própria sensação de impotência juvenil na qual minha geração esteve inserida (se é que ainda não esteja) e talvez mais ainda para um estudante de um curso tido como proposto a investigar as "raízes" dos problemas sociais brasileiros... Em segundo lugar, identificava aquilo que Nóvoa (1999) chamou de "excesso de discursos" e "pobreza das práticas", e que se traduzia numa grande disputa de vaidades entre professores e alunos com frágeis preocupações concretas de inserção e intervenção na realidade social. A preocupação com a construção da representação e status do "intelectual acadêmico" se sobrepunha à da construção e formação política e social do cientista social.

Foi somente na Licenciatura, quando resolvi "ver" o que se fazia e discutia na Faculdade de Educação e aliada à necessidade de circunscrever melhor minha atuação profissional, que me interessei em trabalhar com educação. Por outro lado, "encantado" com a "dimensão prática" da área educacional, acreditava que por aquele caminho encontraria as "respostas" para o meu trabalho de educador que o "lado" cientista social não conseguia dar conta. Desde 1999, tenho trabalhado como educador e professor, seja no ensino formal, seja no chamado terceiro setor. Trabalhos como arte-educação com meninos em situação de rua no centro da cidade de São Paulo; coordenação de projeto social de prevenção à violência em escolas particular, municipal e estadual; docênciaem escolas particulares em História, Sociologia e Geografia, têm constituído minha vida profissional, desde então.

A busca pela pós-graduação representava, naquele momento de finalização da Licenciatura (2003), a tentativa de "conciliar" a intensa busca pelas ditas "questões teóricas" que aprendi a gostar nas Ciências Sociais com a fascinação a respeito do que a Educação reflete contemporaneamente, sobretudo no que tange à prática educativa escolar e seu desafio de produzir mudanças na realidade social brasileira, principalmente aqueles que por ela são diretamente afetados. 
Tal ingenuidade de dicotomizar teoria e prática só foi se diluindo com o caminhar da pesquisa e do aprofundamento da atuação profissional. Apoiado em Canário (1996), compreendi a importância de conceber a relação teoria-prática de forma indissociável, pois "teorizar" sobre educação é em si mesmo, olhar e conceber de outra forma a própria prática de educador, assim como é esta última que alimenta e subsidia a abertura de novas formas de pensar o fenômeno. Enfim, a idéia de que a prática é o lugar de aplicação da teoria foi se esvaziando e tornando a expectativa de "compreender para transformar" uma idéia ainda necessária, porém muito mais complexa.

Após leituras que abordavam a relação escola e sociedade - suas interferências recíprocas, a capacidade das escolas em trazer respostas ao status quo pedagógico, e a delimitação do que a contemporaneidade tem exigido delas - decidi encarar o desafio de transformar minhas questões em projeto de pesquisa de mestrado apresentado à FEUSP em 2003.

Paralelo a isto, naquele mesmo $2^{\circ}$ semestre de 2003, estava terminando o curso de Licenciatura e fiz dos trabalhos finais de duas disciplinas - Métodos de Ensino em Ciências Sociais II e POEB (Política e Organização da Educação Brasileira) - um relatório analisando o projeto político-pedagógico de uma Escola Municipal de Ensino Fundamental (EMEF) na cidade de São Paulo. Por já ter anteriormente estabelecido um vínculo com aquela instituição escolar - o que me facilitou, evidentemente, a entrada - percebia, como "observador distante", que aqueles profissionais da educação estavam, há alguns anos, buscando fazer um trabalho social e pedagógico "diferenciado". Mas o que haveria de ser este "diferencial”? Pois deste relatório entregue no final de 2003 emergiram alguns elementos que pareciam importantes e motivadores de uma maior e mais profunda investigação.

A organização do trabalho pedagógico, o investimento na formação docente, a montagem de uma sólida equipe gestora, a busca em estabelecer relações mais democráticas entre alunos, professores, coordenação e direção, a iniciativa da escola de abrir seus portões aos fins de semana para a comunidade com a oferta de atividades culturais e esportivas, a grande reforma física e material da unidade escolar (fruto de investimentos não só estatais, mas também de organização da própria comunidade escolar), enfim, aquele ambiente escolar/educativo atraia minha atenção por mostrar uma intencionalidade pedagógica no estabelecimento dos rumos e prioridades daquela instituição escolar, que infelizmente não se costuma ver nos estabelecimentos de ensino público nacional. Ficara instigado em investigar quais caminhos percorrera aquela instituição e seus integrantes ao longo daqueles anos; que dificuldades lhes apareceram e quais soluções e alternativas encontraram; quais eram suas 
"posições" pedagógicas e com qual(is) visão(ões) de educação trabalhavam; como se organizavam e o que priorizavam estabelecer como relação de ensino-aprendizagem. Por conta destas inúmeras questões que me circundavam, percebi que o foco de investigação que se colocava diante de mim era algo que abarcasse o significado e a existência da escola como um todo. Dessa forma, tanto para o estágio que se iniciava quanto para o projeto de pesquisa que confeccionava estabelecia como foco de análise o currículo da escola, tendo como metodologia um estudo de caso.

Entretanto, e como já dera pistas logo no inicio desta apresentação, precisava "colocar" esta escola e seu currículo sob um pano de fundo que contemplasse as ambições e inquietações de um cientista social, e que gosta muito de Filosofia. Buscando temas que falassem a respeito dos desafios e dilemas que vivem as escolas contemporaneamente sob a luz das grandes transformações sociais e filosóficas pelas quais passamos, deparei-me um dia, com um texto que distinguia a passagem da modernidade para a pós-modernidade estabelecendo uma relação em como isso afetava o trabalho e a vida nas escolas. Lembrei-me das aulas de sociologia. Pronto! Aí estava a "conciliação" que buscava. Não que acredite ter tido realmente tanta lucidez e clareza deste processo, no entanto, acredito menos ainda que estas combinações tivessem ocorrido por acaso.

Assim, tinha grande parte dos elementos de que precisava para compor de fato o projeto de pesquisa acadêmica. Tinha o campo da pesquisa empírica (uma EMEF), seu foco (o currículo escolar), uma base teórico-filosófica (o debate modernidade - pós-modernidade) e um método de pesquisa ${ }^{1}$. Entretanto, já ali, na gênese do projeto de pesquisa e depois no decorrer das atividades acadêmicas, inclusive de orientação, me deparava com uma dificuldade que colocaria grandes desafios à minha pesquisa: como relacionar a (re) produção da vida cotidiana escolar, o dia-a-dia de professores, alunos, coordenadores, diretores e comunidade do entorno com questões e mudanças "pós modernas"? Seria possível vincular o trabalho dos profissionais da educação e os rumos da escola no cotidiano às mudanças que atingiam não só a ordem epistemológica do conhecimento científico e a ordem ética das ações humanas, como também o mundo do trabalho sob o impacto das novas tecnologias e da globalização e do crescimento dos interesses econômicos supranacionais sobre os mecanismos institucionais tradicionais do Estado-Nação? Vislumbrava aí uma nebulosidade

\footnotetext{
${ }^{1}$ Inicialmente pensara em uma pesquisa-ação, mas que com o passar do tempo foi se mostrando cada vez mais impraticável. Após algumas leituras me dei conta que estava fazendo muito mais um estudo de caso do que qualquer outra coisa.
} 
que parecia ser, ao menos, de ordem metodológica. O desafio da "conciliação" novamente batia à porta...

Dessa forma, em minha trajetória empírica, o que fiz, antes de focar de fato no currículo, foi mudar constantemente o foco da pesquisa, a fim de satisfazer a necessidade de encontrar respostas no âmbito social, pedagógico, concreto para as questões éticas, epistêmicas, abstratas. Se inicialmente tinha o projeto político-pedagógico, passei minha atenção para a questão propriamente da produção e construção do conhecimento na escola como foco da pesquisa empírica. Não satisfeito, pois achava que seria muito difícil investigar como o trabalho com o conhecimento entre professores e alunos no PPP seria afetado (ou não) pela, vamos dizer, crítica ao modelo positivista de conhecimento, parti para compreender qual o papel, o significado que a escola tem hoje, debatendo assim como que este pensamento pósmoderno, no sentido mais propriamente de crítico da modernidade, afeta e interfere na definição dos rumos que a escola toma para si. Consequentemente me vi diante de um foco que, ao invés de me fazer melhor ver um fenômeno específico, colocou-me diante de uma questão demasiado ampla, praticamente incomensurável. Tal impasse me levou por fim, após debruçar-me em como tinha interpretado os dados empíricos do estudo de caso, a considerar que o currículo da escola poderia satisfazer minhas demandas de investigação do trabalho. Isto, sobretudo, por ter entrado em contato com os estudos no campo do currículo e assim vislumbrado grande fertilidade para o debate tanto teórico-conceitual quanto prático-empírico.

Esta virada de século e milênio em diversos setores da sociedade e áreas do conhecimento aponta para uma condição de crise nas múltiplas relações humanas. Estamos diante de um cenário em que certezas se desestruturam, crenças se abalam, valores e crenças são postos em questão (Moreira, 1998). A crise se configura por aquilo que Moreira (idem:14/15) caracteriza pelas "contradições objetivas, decorrentes da perda do poder explicativo do aparato conceitual e/ou da visão de mundo da teoria, e vivenciadas intersubjetivamente pelos sujeitos concretos e históricos envolvidos".

Nesta linha, muitos autores têm vinculado essas inquietações e buscas aos acontecimentos, formas de pensamento e movimentos culturais emergentes do pós-guerra. $\mathrm{O}$ cenário filosófico, social, econômico, político e cultural demarcado principalmente a partir dos anos 60 do século XX, levou a um movimento de questionamento e crítica ao "projeto" da modernidade - iniciado embrionariamente com o Renascimento e aprofundado com o 
Iluminismo no século XVIII. O aprofundamento de suas contradições, a evidência de seus feitos e limitações, a explicitação de suas promessas e não realizações levaram à idéia de que o que vivemos, o que questionamos e a orientação de nossas ações contemporâneas são fruto de algo que se pode chamar de crise, crise da modernidade.

Tal processo crítico de reflexão levou, e ainda leva, teóricos a chamar de pósmodernidade (Lyotard 1986, Featherstone 1995, Jameson 1996, entre outros), alta modernidade (Giddens 1990) ou neomodernidade (Rouanet 2000), o novo paradigma que daí advém: seja através da continuidade e aprofundamento de certos valores existentes, seja de movimentos de rupturas de certas práticas sociais devido à radicalidade de suas contradições internas (Jameson 1985), o que se vê é um cenário de grandes transformações sociais afetando as múltiplas dimensões da sociedade e do sujeito moderno. Nesse sentido, questões essenciais que o homem ocidental tem se colocado - como conhecer o mundo, como se organizar política e socialmente, como estabelecer as relações de troca, materiais e simbólicas, assim como o próprio sentido da formação e das relações humanas, como e o quê ensinar - vêm à tona sob a necessidade de re-constituir rumos e significados.

Naturalmente nem a educação em geral e nem as escolas em particular ficam aquém ou além desta crise do "projeto moderno". Haja vista que a escola é uma instituição criada na e para a realização dos ideais da modernidade, estando, assim como outras instituições, dentro deste processo de constituição do sujeito moderno, o que leva a considerar um movimento dialético na relação escola-sociedade (Souza 2001a, Veiga 2001a), quer dizer, se a sociedade define e/ou influencia na concepção e formação das escolas que esta quer para si, essas últimas, por sua vez, no exercício de sua prática social e educativa, são capazes de, ao menos, delinear um tipo de sociedade que almejam.

Se a modernidade está, de alguma forma, passando por uma crise, afetando suas múltiplas faces e instituições, e a escola é, essencialmente, uma instituição moderna, pode-se considerar que os valores e práticas que envolvem os saberes educacionais, assim como o significado e o papel da escola, também são afetados por estas mudanças.

Cabe então levantar alguns questionamentos: o que significa dizer que o "projeto" da modernidade está em crise? No que consiste este repensar ou, como chegam a propor outros pensadores, este romper com tal paradigma? Indo além, como a crise da modernidade e o advento de uma "nova" condição social afetam o projeto de educação e das escolas? O que deve mudar e o que deve permanecer? Por outro lado, como elas enfrentam os dilemas que a dinâmica social - em suas contradições, paradoxos e consensos - coloca à prática pedagógica 
cotidiana? Qual sua capacidade de responder às novas exigências e demandas sociais advindas desta condição que se configura?

Em contrapartida, o que se quer dizer, ao supor que a modernidade não representaria mais os valores e objetivos das configurações contemporâneas, e mais, chamar este novo momento de pós-modernidade? Por conseqüência, seria este, de um modo geral, uma ruptura ou um prolongamento dos ideais modernos, um novo paradigma de compreensão da realidade ou uma nova condição social, e de um modo específico, uma periodização histórica ou um movimento cultural de um determinado segmento social?

Se for além, o que significa aceitá-la, qual sua capacidade de cumprir (ou de criticar e romper com) as promessas da modernidade, quais seus riscos e ilusões para um futuro que se mostra incerto e muitas vezes perigoso, e mais, quais suas conseqüências à educação e às instituições escolares que se desenvolvem neste início de século? E como este debate se instaura e penetra desde o campo acadêmico até o campo escolar brasileiro?

Sabe-se que estas questões de ordem, sobretudo, filosófica têm intrigado pensadores e estudiosos preocupados com os caminhos de nossa sociedade e da escola na contemporaneidade e sem dúvida impulsionarão também minhas buscas como pesquisador.

Por conta disso, levanto como proposta de investigação, analisar as contribuições $e$ limites que o pensamento pós-moderno traz à teoria e prática do currículo escolar, assim como, empiricamente, analisar como este último - a partir do estudo de caso - tem respondido e dialogado com tais proposições. Em poucas palavras buscar-se-á, assim, analisar como o pensamento, o discurso e a condição pós-moderno podem e/ou afetam o currículo e a vida da escola.

Tornam-se, assim, estes os objetivos específicos da pesquisa:

- Mapear e situar o debate entre modernidade x pós-modernidade e suas implicações para o campo teórico educacional em geral e o currículo em particular.

- Analisar as múltiplas dimensões da vida escolar e as ações, práticas e discursos dos diferentes integrantes da escola - professores, alunos, direção, coordenação e agentes escolares.

- Confrontar as representações que os diferentes integrantes da comunidade escolar fazem das relações sociais em que estão inseridos e como se configuram as relações de poder no âmbito dessas representações.

- Apontar e analisar como as escolas estão respondendo às questões postas pelo pensamento, o discurso e a condição pós-modernos, e seu desdobramento pósestruturalista a partir deste estudo de caso. 
$\mathrm{Na}$ medida em que a investigação central é estudar como a escola está produzindo respostas concretas aos problemas colocados pela dinâmica social contemporânea, considero adequado um estudo de caso como forma de compreender o cotidiano da prática escolar em toda sua riqueza, sendo assim, capaz de abordar as suas múltiplas dimensões organizacionais, pedagógicas e sociopolíticas - nos dizeres, fazeres e saberes dos diferentes agentes da vida escolar. Outra razão que sustenta esta escolha é o fato de que esta abordagem parte do princípio de que a pesquisa pode modificar parte de seus problemas e hipótese no decorrer da investigação empírica, pois entende que o campo da pesquisa é um espaço aberto de manifestações sociais e culturais e que o pesquisador não irá lá "encontrar as respostas", mas sim, deixar emergir de lá as perguntas.

Quanto às etapas da pesquisa, pode-se expressá-las da seguinte forma: construção do referencial teórico e estudo de caso:

Referencial teórico:

- Levantamento bibliográfico da produção teórica - filosófica, sociológica e educacional - referente à crítica da modernidade e ao advento do pensamento pósmoderno.

- Levantamento bibliográfico da produção teórica sobre a educação escolar como ideal moderno, assim como sobre os ideais pedagógicos constitutivos da educação brasileira.

- Levantamento bibliográfico da produção teórica sobre o campo do currículo, em suas teorizações crítica e pós-crítica/pós-estruturalista.

Estudo de caso:

- Observação participante e diário de campo: a) das reuniões pedagógicas de Horário de Trabalho Pedagógico (JEIs); b) da vida em sala de aula - relação professor, alunos, conhecimento, avaliação; c) das atividades extra curriculares e das atividades e eventos culturais da escola; d) do envolvimento cotidiano com a escola e o entorno.

- Entrevista: por meio de questionários semi-estruturados com professores, alunos, direção, coordenação pedagógica, supervisão pedagógica e agentes escolares.

- Levantamento e análise dos documentos da escola referentes à elaboração, construção e avaliação do projeto político-pedagógico, do histórico e mudanças na 
escola ao longo dos últimos dez anos e do planejamento de curso de alguns professores do Ensino Fundamental II.

- Sistematização, análise e interpretação dos dados do campo.

Em síntese, pode-se dizer que o capítulo I traz à luz da reflexão o debate levantado pelo pensamento pós-moderno aos estatutos da modernidade e seus impactos às diferentes dimensões da vida e da teoria social. Faz-se considerações também as possíveis contribuições e limitações deste pensamento para a teoria social e de sua intersecção com o campo educacional.

No capítulo II, o foco central refere-se à análise da constituição dos ideais modernos de educação e escolarização. Por conseqüência, procura-se analisar a educação/escolarização à luz do processo de modernização do Brasil e da América Latina. Em seguida, aprofunda-se a discussão sobre das teorias pedagógicas centrais na educação brasileira do século XX.

O capítulo III é o espaço do estudo empírico, o momento de dar "voz" à escola, aos diferentes integrantes e analisar as ações, práticas e discursos que sustentam o currículo da escola. Busca-se contemplar as múltiplas dimensões da vida escolar - organizacionais, pedagógicas e sociopolíticas.

O capítulo $I V$, por fim, é dedicado ao aprofundamento da discussão do campo teórico do currículo, sobretudo, em sua concepção crítica e pós-crítica/pós-estruturalista e à retomada da análise dos dados empíricos à luz deste referencial teórico. Busca-se assim, analisar como a escola e seu currículo se colocam diante do pensamento, discurso e condição pós-modernos, e como a posição pós-estruturalista pode "ler" os fenômenos do currículo escolar. 


\section{Capítulo I - A contemporaneidade: a modernidade e o pensamento pós-moderno - os conceitos, o debate e as fronteiras teóricas.}

Para iniciar a investigação recorro a uma proposição filosófica essencialmente moderna colocada por Foucault ${ }^{2}$ (mimeo:s/d) quando este se remete ao Iluminismo. Orientado pelo que este autor apontou ser o próprio manifesto da modernidade ${ }^{3}$ realizado por Kant quando se perguntou o que era o Iluminismo, sigo a mesma dúvida filosófica ao interrogar o que é a nossa atualidade, o nosso presente - a contemporaneidade. Qual é, portanto, o seu sentido, seu valor e sua singularidade. Assim, interrogar o que é esta crise da modernidade e a emergência de um pensamento pós-moderno, seus níveis de ruptura ou de continuidade com a modernidade (Foucault s/d e Jameson 1996) e, por consequiência, quais são as relações com os princípios da educação e principalmente com a prática social e educativa das escolas, é o que orienta filosoficamente esta investigação.

Mas afinal o que é a contemporaneidade em sua dimensão educacional? É possível defini-la? Que significa chamá-la de pós-moderna ou pós-modernista? Se esta existe, em que termos pode ser considerada válida? É uma mudança paradigmática que tem alterado as esferas da vida social, moral e do conhecimento, e que sustentará um novo "estágio" do desenvolvimento humano ou é apenas um movimento cultural, e, portanto, historicamente relacionado à fase de desenvolvimento do capitalismo atual, assim como de um segmento sociocultural produtor do discurso pós-modernista? Ela afeta os princípios educacionais e a vida escolar? Em que termos?

Para que não se caia, de antemão na própria "euforia pós-moderna", há alguns apontamentos cautelosos de Jameson (1996) no que se refere ao uso do par pósmodernismo/pós-moderno. Ele afirma não ser possível não usá-lo, embora seja um termo não só contestado como, muitas vezes, também, conflitante e contraditório. Rouanet (2000:229) confirma: "a polissemia é irritante quando se trata de definir um conceito" e este termo, sem dúvida, está entre os mais controversos. Jameson (1996:25grifo nosso) ressalta que o pósmodernismo não pode ser "algo que se possa estabelecer de uma vez por todas e (...) o conceito, se existe um, tem que surgir no fim, e não no começo de nossas discussões do tema."

\footnotetext{
${ }^{2}$ Traduzido a partir de FOUCAULT, Michel. Dits et Écrits. vol. IV. Paris: Gallimard, Pág. 679-688, 1994 (mimeo).

${ }^{3}$ Foucault se refere ao ensaio de Kant "Resposta à pergunta: O que é o Iluminismo?" In Paz Perpétua e outros opúsculos. Lisboa: Edições 70, 1989.
} 
Enfim, tomando os ensinamentos de que "estamos longe do fim” não é necessário ir muito além para constatar fervor, conflitos, divergências e ambigüidades quando o que se pretende é nomear e caracterizar os fenômenos e processos sociais no qual estamos inseridos - a atualidade - assim como, os ditames que devem orientar a prática educativa contemporânea.

Della Fonte (2004:1 mimeo), ao situar o debate sobre a agenda pós-moderna e a educação, interroga se é possível ainda sustentar que a prática educativa seja guiada por valores com validade universal, ou se se deve concebê-la somente inserida em "éticas locais"? O projeto de formar um sujeito autônomo, livre, consciente de sua razão se mantém como um ideal educativo incondicional? Os saberes pedagógicos, os métodos de ensino, a seleção dos conteúdos encontram sentido na própria realidade objetiva ou deve-se afirmar que só existem como modos de produção discursivos culturais específicos?

Tais questões, dentre outras, remetem, no campo da produção do conhecimento educacional contemporâneo, à validação dos princípios, valores e práticas constituídos a partir do "projeto" da modernidade.

\section{Caracterização do debate - contexto e conceitos}

\subsection{A modernidade e a crise}

Não é crucial preocupação deste estudo, portanto, esgotar até que ponto o uso do par pós-modernismo/pós-moderno é o mais adequado para representar um conjunto de modificações sociais sentidas em diversas áreas, na medida em que dele se tem feito uso nas mais diversas áreas da manifestação humana. Segundo Rouanet (2000), por uns tem sido aplicado exclusivamente à arquitetura, ou à literatura, ou à pintura, ou seja, aos domínios da arte. Por outros, à totalidade da esfera cultural, abrangendo também a ciência e a filosofia. Outros autores, ainda, aplicam o termo à economia, à política, à sociedade em geral.

O que importa aqui, como foi dito, é conceber que algo está em mutação, em crise. E nesse sentido, se refere ao que a modernidade, desde o Renascimento e, sobretudo com o Iluminismo, realizou ao romper com os grilhões da estrutura de privilégios religiosos e feudais. Se não se sabe como chamar e definir o que sente na vida cotidiana, ou seja, “notamos o que não é mais, mas não conhecemos o que está por vir" (Rouanet e Mafessoli, 1994:22), pode-se concordar com outra afirmação de Rouanet (2000:268): “o homem contemporâneo está cansado da modernidade"; se ela não se esgotou, com certeza envelheceu. 
Ora, se é possível concordar que a pós-modernidade se define, no mínimo, por um questionamento da modernidade, no todo ou em parte, refletindo sobre seus limites e limitações, torna-se necessário precisar a que se refere a modernidade e o advento de sua crise. O que importa não é partidarizar em prol ou contra o pensamento, discurso ou condição pós-moderno, mas sim alicerçar-se criticamente aos estatutos da modernidade.

Pode-se dizer que a modernidade, segundo alguns autores ${ }^{4}$, num conjunto de fenômenos novos, foi constituída historicamente por um progresso científico racional que transforma conhecimento em tecnologia; pela industrialização e racionalização do trabalho; por um conhecimento enciclopedista; pela busca da universalização do conhecimento e da escola como uma instituição público-estatal; pela urbanização dos espaços sociais; pela ampliação da rede de comunicação; pela massificação da produção e do consumo; pela criação e consolidação dos Estados Nacionais, burocraticamente estruturados e cada vez mais poderosos e controladores; pela expansão dos mercados além mar, um mundo com fronteiras cada vez menos limitadas; e pela consolidação do ideal liberal-burguês de sujeito.

Vale ainda notar os apontamentos de Max Weber $(1991,1967)$ quando analisa que a modernidade trouxe consigo uma racionalização da vida com conseqüências tanto às esferas econômicas e políticas quanto culturais. Quanto às duas primeiras, Weber (1991) aponta não só a organização racional da produção baseada no cálculo contábil e a utilização técnica de conhecimentos científicos adicionada à ética protestante da poupança e sem luxúrias, como a dominação legal e o monopólio da força física exercidos pela administração estatal. Quanto à cultural, um processo de desencantamento do mundo por conseqüência da diferenciação e autonomia que ciência, arte e moral adquiriram em relação à religião. Quer dizer, as velhas explicações religiosas perdiam então a hegemonia, e em parte a validade, como cosmo visão.

Reside também como eixo central do "projeto" moderno, a crença na razão como instrumento universal e emancipatório da condição humana, ou seja, que por ela a humanidade de fato "atingiria sua maioridade" (Kant 1989). É através dela que o homem sairia do reino da ignorância, da dominação, da pobreza, do despotismo e inversamente, se emanciparia, seria livre, conhecedor mais e melhor da natureza e de si mesmo e por conseqüência estaria em permanente progresso (Goergen 2001).

Levado a cabo pela crítica à razão e sua instrumentação, pelos falsos poderes que ela conquistou, pela indissociação entre os caminhos do saber e os mecanismos do poder, os

\footnotetext{
${ }^{4}$ Cf. Bermam (1986), Rouanet (2000), Fridman (2000), Smart (1993).
} 
pensadores já do final do século XIX e, sobretudo do século $\mathrm{XX}^{5}$, que viram e viveram o que Hobsbawm (2003) chamou de "Era da Catástrofe", ou seja, duas grandes guerras mundiais, campos de concentração de Auschwitz, a bomba atômica, os regimes totalitários, a grande depressão americana, a eminência da destruição dos ecossistemas etc., não deixaram de questionar criticamente os rumos da modernidade traçados pela e para a humanidade.

Boaventura de Souza Santos (1999:77) contribui ao debate ao analisar o projeto sociocultural da modernidade assentado sob dois pilares: o da regulação e o da emancipação. O primeiro é constituído pelo princípio do Estado, do mercado e da comunidade enquanto o segundo é regido pela lógica das racionalidades moral-prática (ética e direito moderno), estético-expressiva (artes e literatura) e cognitivo-instrumental (ciência e técnica). Ao ressaltar que os dois pilares e seus respectivos princípios e lógicas se correlacionam, equilibrando-se, argumenta que o que se viu, entretanto, foi o predomínio do pilar da regulação sobre o pilar da emancipação. Para este autor (idem:236):

À medida que a trajetória da modernidade se identificou com a trajetória do capitalismo, o pilar da regulação veio a fortalecer-se à custa do pilar da emancipação num processo histórico não linear e contraditório, com oscilações recorrentes entre um e outro, nos mais diversos campos da vida coletiva e sob diferentes formas (...).

A dualidade regulação/emancipação favoreceria a compreensão da contraditoriedade, por exemplo, do uso da razão moderna: se por ela pudemos conhecer mais autonomamente o mundo e agir eticamente sobre ele, também por ela foi posto a serviço a natureza e o próprio homem de forma instrumental e exploratória. Numa palavra, se conhecemos mais o mundo hoje, produzimos melhores tecnologias capazes de destruí-lo.

No caso da instituição moderna escolar, vê-se o caráter regulatório no processo de disciplinarização dos corpos e saberes, no estabelecimento das normas e regras e no controle do desempenho de seus integrantes (Foucault, 2000). Da mesma forma, atribui-se também a ela, a função de humanizar o próprio homem, possibilitando que este aprenda a conhecer a natureza, o outro e a si mesmo, assim como, se socializar em um conjunto de valores eticamente necessários para viver em sociedade, de forma a libertar o homem das próprias amarras que ele pôs para si. Voltarei a este ponto no capítulo seguinte, referente ao papel da escola na modernidade.

\footnotetext{
${ }^{5}$ Refiro-me, no mínimo, nas obras de Marx, Nietzsche, Freud, Heidegger, Foucault e dos que integraram a chamada Escola de Frankfurt.
} 


\subsection{O debate contemporâneo da crítica da modernidade - definições, interpretações e controvérsias}

Adentrar na produção teórica que começa a ser produzida já a partir da década de 60 , e sobretudo nas décadas seguintes, leva a perceber que, além de polissêmico e controverso, como já foi dito, por trás do termo pós-moderno não se sustenta uma teoria ordenada e sistematizada em fundamentos comuns mesmo por aqueles que buscam fundamentá-lo. Paradoxalmente, talvez o que queiram seja exatamente a ausência de fundamentação! É por conta disso que alguns autores preferem considerar o termo muito mais no plano da consciência ou do pensamento - Goergen (2001) profere a emergência de uma "nova consciência"; Rouanet (2000) de que é muito mais um "estado de consciência" que se prenuncia do que uma mudança real; e Pérez Gómez (2001) de que o termo é produto muito mais do pensamento da cultura intelectual-acadêmica - do que das mudanças que a realidade produz. Della Fonte (2004:7 mimeo), apoiada em Wood 6 , evoca ainda a idéia de uma "agenda pós-moderna", "composta por uma vasta gama de tendências intelectuais e políticas que surgiram nos anos recentes". A pertinência desta última concepção é, não só não cair num reducionismo conceitual e classificatório para o termo pós-moderno como ampliar o foco de análise. Diferentes perspectivas teóricas poderiam assim perpassar o "terreno" do pensamento pós-moderno, sem necessariamente se filiar a $\operatorname{ele}^{7}$.

Embora não seja a finalidade deste trabalho esmiuçar com a devida profundidade a bibliografia e o debate do que consiste o pensamento pós-moderno, a "agenda pós-moderna" ou a condição pós-moderna, mas sim identificar a pertinência, ou não, dos elementos que eles evocam para refletir sobre o currículo das escolas contemporâneas, considera-se necessário trazer à luz do debate as esferas com as quais procuram dialogar.

O movimento artístico pós-modernista é um dos próprios reivindicadores da autoria do termo. Rouanet (2000:248) afirma ter sido na "esfera estética (...) que o termo pósmodernismo foi usado pela primeira vez". Tomando "emprestado", então, uma "síntese" de

\footnotetext{
${ }^{6}$ Cf. WOOD E. T. “O que é a agenda pós-moderna?” In WOOD, E.M. \& FOSTER, J.B. (org.). Em defesa da história: marxismo e pós-modernismo. Rio de Janeiro: Jorge Zahar, 1999.

7 Isso sem dúvida traz enormes dificuldades como, por exemplo, haver autores que por discutir "temáticas pósmodernas" são incluídos (a contragosto) sob a tutela do rótulo. Outro ponto é a própria "intencionalidade" pósmoderna de não se atribuir um corpo teórico autêntico e explícito, o que acarreta comprometimentos, no mínimo, de ordem ética e epistêmica. Inclusive Habermas (1990:309) a respeito disso afirma que os discursos pósmodernos "não podem e não querem prestar contas do lugar que ocupam" no que se refere à crítica radical feita à razão moderna.
} 
Featherstone (1995:25) em relação às características do pós-modernismo associado às artes em geral, se compreende o que se quer dizer:

\begin{abstract}
Abolição da fronteira entre arte e vida cotidiana; a derrocada da distinção entre alta-cultura e cultura de massa/popular; uma promiscuidade estilística, favorecendo o ecletismo e a mistura de códigos; paródia, pastiche, ironia, diversão e a celebração da 'ausência de profundidade' da cultura; o declínio da originalidade/genialidade do produtor artístico e a suposição de que a arte pode ser somente repetição.
\end{abstract}

Quanto à dimensão cultural segue-se outra proposição de Featherstone (idem: 13). Para ele, "é difícil separar a questão do pós-moderno do visível aumento do interesse por teorizações da cultura, tema que foi promovido de uma condição periférica para o centro de vários campos acadêmicos". Nesse sentido, a própria intrigância da pós-modernidade é resultado da relevância ou expansão do papel da cultura nas sociedades contemporâneas.

Jameson (1985:17) ao considerar o pós-modernismo "um conceito de periodização cuja principal função é correlacionar a emergência de novos traços formais da vida cultural com a emergência de um novo tipo de vida social e de uma nova ordem econômica”, o chamado capitalismo tardio ou multinacional, argumenta ser a transformação da realidade em imagem e a perda do sentido de temporalidade, ou seja, o sujeito vivendo presentes contínuos sem conseguir estabelecer, de fato, significados, as formas atuais do fazer cotidiano. Foi esta indistinção entre realidade e imagem, produzida principalmente pela intensa presença da mídia nos modos de vida contemporâneos, que levou teóricos a chamar de sociedade do "espetáculo" e do "simulacro"8 os fenômenos culturais contemporâneos. No campo educacional, vimos, ao menos, nas últimas décadas uma crescente preocupação teórica com os estudos referentes ao chamado Estudos Culturais, à cultura escolar e por conseqüência, do que é e deve compor o currículo escolar.

Quanto à esfera econômica, sabe-se que a pós-modernidade não questiona qualquer ruptura com o sistema capitalista, ao contrário, e é nisso que Jameson (1996) aposta sua tese, de que estamos no estágio do capitalismo tido como multinacional, sendo então o pósmodernismo o movimento cultural fruto desta fase. Relacionado intrinsecamente à globalização, este momento tem como características essenciais a ruptura com as fronteiras nacionais e uma adaptação mais flexível às demandas da produção e dos mercados consumidores. Para Fridman (2000), a especialização flexível corresponde à desintegração das empresas e descentralização das plantas industriais. Harvey (1999) considera a compressão do

\footnotetext{
${ }^{8}$ Cf. Baudrillard, Jean. Simulacros e simulação. Lisboa: Relógio d’água, 1991.
} 
espaço-tempo, com a intensificação das relações sociais em escala mundial ligando localidades antes distantes, a grande adaptabilidade dos empreendimentos capitalistas e a volatilidade do capital, as grandes mudanças sentidas nos últimos tempos na produção. Por consequiência, tem-se uma "assimilação da tecnologia da informação à atividade produtiva e a adaptação da força de trabalho a essas novas circunstâncias", produzindo, o que se chama de "novos excluídos globais" (Fridman 2000:49).

Vê-se assim que tais condicionantes econômicos estão relacionados intrinsecamente às reconfigurações do mundo do trabalho. Libâneo (1996:144) argumenta que, por conta destas mudanças no sistema econômico mundial, tem havido "uma intelectualização do processo de produção à base de uso mais amplo do conhecimento, da informatização, dos sistemas de comunicação, demandando mão-de-obra mais qualificada". A flexibilização das relações de trabalho, o subemprego e o próprio desemprego estrutural colocam em questão a eficácia da escolarização em massa, o sentido da prática educacional e a real importância de formar indivíduos aptos para um mercado de trabalho restrito, desigual e excludente (Giroux 1996:71). Canário, Alves e Rolo (2001) alertam ainda para os novos processos de exclusão social mesmo com o maior acesso ao ensino público como temos visto no Brasil nas últimas décadas. O paradoxo consiste, portanto, no fato de que embora se pensasse que tendo o indivíduo se inserido no universo escolar (e por mais tempo), ele estaria assim sendo incluído socialmente - exercício profissional associado ao acesso aos bens de consumo, à cidadania vemos, na verdade, um enorme aumento da exigência da qualificação profissional, uma desvalorização dos diplomas e a própria ausência da oferta de emprego. A chamada sociedade da informação exige da educação e dos sistemas de ensino produzir seres capazes de processar os mais variados e múltiplos tipos de informações, para supostamente se inserir em um mundo do trabalho que requer tais habilidades e competências e que, como temos visto, não oferece postos de trabalho para todos.

As possibilidades de ação política e o papel do Estado Nacional têm sido também objetos de reflexão deste debate. Uns apostam nos alicerces liberais de diminuição ou até falência do Estado moderno, enquanto outros vêem nos novos movimentos sociais - ações locais com interesses específicos com potencial universalizável - o resgate da condição política do sujeito moderno que fora diluído pela burocratização do poder público e pelo "representativismo" democrático. Para Santos (1999), do ponto de vista emancipatório, é possível e necessário pensar em novas formas de cidadania baseadas em critérios de participação e, portanto, não residentes na lógica liberal de cidadania, ou seja, para além do exercício dos direitos e deveres do indivíduo e da liberdade política de eleger seus 
representantes. A contribuição dos novos movimentos sociais estaria, portanto, no alargamento da dimensão política para além do marco liberal que dicotomizou Estado e sociedade civil.

Este debate coloca em pauta a necessidade de repensar qual é o papel e função do Estado atual e sua relação com o indivíduo e a sociedade civil, e por conseqüência qual a possibilidade de enfrentamento e crítica (ou adesão) que a emergência de uma grande variedade de práticas políticas de pequenos grupos tem diante da estrutura econômica capitalista. A fragmentação do sujeito contemporâneo, o declínio dos partidos políticos baseados nos interesses de classe e dos sindicatos defensores de categorias inteiras têm levado à construção de uma identidade política que enfraquece os movimentos sociais de classe (ou pelo menos mascara e neutraliza a sua força) ao passo que faz emergir movimentos sociais por "temas" - sexualidade, etnias, ecologia, acesso à moradia ou ao ensino superior, etc. (Fridman 2000, Jameson 1996, Santos 1999). Fruto do consumismo hedonista, da liberdade incondicional do indivíduo em relação à sociedade, do neoliberalismo político-econômico das últimas décadas, vê-se uma "grande defesa pelos direitos". Nas palavras de Hobsbawm (2003:332), a ação política contemporânea foi "reduzida simplesmente às manifestações de preferências individuais, e reivindicações de que a lei reconhecesse a supremacia dessas preferências". Enfim, Fridman (2000:75) com base em Jameson, sinteticamente analisa este dilema ao afirmar que:

Não se duvide da colonização do inconsciente no capitalismo tardio, mas que também não se minimizem o campo de iniciativas e possibilidades de ação de homens e mulheres contemporâneos na politização do cotidiano.

Sabemos que os tópicos acima estão dialeticamente relacionados às dimensões do pensamento filosófico, do papel do conhecimento e da ciência moderna e da própria condição do sujeito contemporâneo. Aqui residem, talvez, as maiores críticas que as correntes do pósmodernismo procuraram colocar ao estatuto da modernidade.

Primeiro a afirmação da carência de qualquer fundamentação universal do pensamento racional e por consequiência da derrocada das metanarrativas históricas (Lyotard, 1986). Goergen (2001:26/27) ao afirmar que a proposição de fim de um projeto de desenvolvimento de homem e da sociedade, se desdobra numa contradição. Se por um lado

representa uma crítica contundente ao projeto moderno naquilo que este tem de fulcral, ou seja, a conquista do progresso através do uso adequado da razão, colocando sob suspeita a ambição política de construção de um 
ser humano melhor e uma sociedade mais justa; (...) pelo outro lado, representa uma louvável abertura para a multiplicidade das vozes culturais espalhadas pelo planeta, não raro emudecidas ou sufocadas pelo centrismo e suposta superioridade da voz que parte do interior da cultura européia.

A tese de Lyotard (1986) do fim das metanarrativas - o liberalismo, o socialismo, a democracia etc. - e do projeto moderno de "realização pela universalidade" - pela razão, verdade, bondade, liberdade, realidade - questiona a concepção filosófica iluminista kantiana que defende a existência de um sujeito transcendental, uma natureza humana essencialista e o destino humano universal. Tal crítica abriu, dentre outras, a possibilidade de questionar a autoridade científica e seu poder de proferir idéias com estatutos absolutos de verdade. Terse-ia, para Lyotard, então, a ciência como apenas mais um discurso dentre os vários existentes. A ciência contemporânea, seria, portanto, um certo modo de organizar, estocar e distribuir certas informações através dos jogos de linguagem (Lyotard 1986). Vale dizer que a crítica mais cabal que se faz a esta tese é se não haveria aí uma grande narrativa subjacente à pregação do fim das grandes narrativas! Como desdobramento necessário, tem-se o risco de cair seja num relativismo cultural e epistêmico exacerbado, seja num niilismo existencial irreversível (Pérez Gómez 2001, Della Fonte 2004, Goergen 2001).

$\mathrm{O}$ que se sabe é que a episteme pós-moderna se legitima pelo heterogêneo, pelo inesperado, pela diferença, pela fragmentação e pela incerteza (Rouanet 2000) e se o fim das metanarrativas colocaria em xeque as totalizações e sistematizações, incorrendo ao vazio dos

'jogos de linguagem', da intertextualidade, das ironias, incoerências e inconsistências dos escritos acadêmicos, por outro lado, focaliza-se mais criticamente nos modos como as teorias são construídas, seus pressupostos ocultos, e questiona a autoridade do teórico para falar em nome do 'Outro'. (Featherstone, 1995:27)

A reconfiguração do papel e função do saber nas sociedades contemporâneas reverbera nas escolas, ao menos, no que se refere ao que deveria compor os currículos escolares (cultura acadêmica x cultura cotidiana) e do significado da relação professor-aluno. Isto na medida em que o primeiro já não sustentaria mais o estatuto de "detentor do saber", ao menos por conta da velocidade e multiplicidade dos meios de informação e comunicação que retiram da escola o atributo antes exclusivo de "fonte" de conhecimento. Por outro lado, se investirmos na tese lyotardiana, na qual as bases de produção do conhecimento estariam sendo deslocadas por conta da força dos meios de comunicação e do desenvolvimento da informática, corre-se o perigoso risco de minar o potencial informativo e sobretudo formativo 
antes atribuído à escola. Não por acaso, há correntes tidas como pós-modernas que pregam o próprio fim da escola.

O elemento acima apontado muda por conseqüência a ordem epistêmica e ética do sujeito contemporâneo. Tanto o conhecimento quanto a moral são colocados num jogo de força que ora puxa para a defesa do subjetivismo e do localismo, ora para a importância do intersubjetivismo e da manutenção do universalismo. Se, por um lado, o conhecimento tornase mais "relativo", instável, incerto e provisório, por outro, reivindica-se sua validade na medida em que ele não atinge alguma universalidade. No campo da moral, se por um lado, incorre-se no risco de só se poder determinar "éticas locais e individuais", aquilo que Lipovetsky $^{9}$ chamou de "individualismo responsável", por outro, Habermas ${ }^{10}$ chama a atenção para a necessidade de normatização da vida social por meio da razão comunicativa, dialógica, sediada na intersubjetividade e na busca do melhor argumento.

Avançar nestas questões leva de algum modo a comentar àquilo que alguns autores chamam de "virada lingüística" (Habermas 1990, Silva 1995) a reconfiguração epistemológica e ontológica do sujeito contemporâneo. Ela se refere à relevância em estabelecer uma relação intrínseca entre linguagem, saber e poder, pois aquele que profere um discurso não o faz desvencilhado de suas buscas de poder e de forma "transparente". Giroux (1993:58) ajuda a compreender a ênfase na centralidade da linguagem ao afirmar que:

O discurso pós-moderno redefiniu a natureza da linguagem como um sistema de signos estruturados no jogo infinito da diferença e enfraqueceu a noção dominante, positivista da linguagem, seja como um código genético estruturado de forma permanente, seja simplesmente como meio lingüístico transparente, para transmitir idéias e significados.

Por conseqüência:

Ao constituir os objetos culturais como linguagem, tornou-se possível questionar radicalmente a visão hegemônica de representação que argumenta que o conhecimento, a verdade e a razão são governados por códigos e relações lingüísticas que são essencialmente neutros e apolíticos.

Por outro lado, pode-se questionar se não se estaria assim, atribuindo à linguagem, aos seus modos operativos de comunicabilidade e às estruturais gramáticas e discursivas o valor de verdade que antes residia na subjetividade. Ou seja, em vez de superar uma metafísica do

\footnotetext{
${ }^{9}$ Cf. Lipovetsky, G. O crepúsculo do dever - a ética indolor dos novos tempos democráticos. Lisboa: Dom Quixote, 1994.

${ }^{10}$ Cf. Habermas, J. Teoría de la acción comunicativa. México: Taurus, 1999.
} 
sujeito incorrer-se-ia no risco de "transcendentalizar" a linguagem ao atribuir a ela o poder de verdade e de ação.

Por fim e por conta dos elementos anteriores, a concepção de sujeito e de subjetividade é, por conseqüência, remexida, reconfigurada. Com a modernidade, o sujeito liberal adquiria o caráter de unidade racional e transparente, autônomo e consciente, ou seja, a ele era atribuída a capacidade de atingir determinados patamares de consciência de sua existência de forma a superar os mecanismos ideológicos e agir de forma livre e emancipatória.

A crítica da modernidade e o pensamento pós-moderno, por outro lado, conceberiam a subjetividade de forma fragmentada, descentrada, provisória e de impulsos contraditórios. Do ponto de vista cultural, segundo Bauman ${ }^{11}$ (In Fridman, 2000) e Featherstone (1995), seria uma identidade fluida, que não se completa, pois depende do que está por vir, o que tornaria o sujeito um "colecionador de experiências" guiado pela urgência dos prazeres imposta pelo hedonismo do consumo. Featherstone (1995) procura inclusive analisar o movimento pósmodernista sob a ótica de uma manifestação cultural resultante da estetização e estilização da vida cotidiana. Fridman (2000) ainda aponta para um enfraquecimento das relações pessoais e de solidariedade, uma superficialidade dos contatos, uma "presentificação" da realidade e uma diluição da dimensão histórica.

Por outro lado, esta concepeção de subjetividade refuta a dualidade, estado préconsciente x consciente, alienado x lúcido, dominado x livre. Desta forma, nas palavras de Tomaz Tadeu da Silva (1993:130), “a consciência é sempre parcial, é sempre fragmentada, é sempre incompleta". Ou seja, a subjetividade é constituída pelas diferentes posições que o sujeito assume, na contingência dos espaços que ocupa e nas relações de poder que estabelece.

Tais “indeterminações" são, em certa medida, fruto do caráter reflexivo deste sujeito. Por refletir sobre sua existência e sua condição de forma contingente, o presente (e o futuro) se apresenta mais incerto, aberto e "determinado" pela contraditoriedade dos impulsos e interesses do sujeito. Pois o ato de refletir sobre a ação é o que a torna, paradoxalmente mais incerta e mutável. Assim, para Gimeno Sacristán (1999:13),

o ceticismo pós-moderno que desestabiliza as práticas sociais, políticas e culturais dirigidas para fins predeterminados, como é o caso da educação, situa-nos cara a cara com nossas forças, nossos fundamentos e nossas responsabilidades. A história não tem teleologia (...).

\footnotetext{
${ }^{11}$ Cf., Baumam, Z. O mal estar da pós-modernidade. Rio de Janeiro: Jorge Zahar Editor, 1998.
} 
Estas considerações iniciais levam a tratar com cautela as possibilidades de aderir ao discurso, condição e pensamento pós-modernos. O relativismo, o ceticismo, o niilismo, o gozo do presente, o individualismo assim como o discurso afirmativo da ausência de um "projeto social emancipatório e universal" casam perfeitamente com os interesses dominantes da classe dirigente do capitalismo neoliberal internacional atual e deixam pouca margem de ação para a educação e para a finalidade da educação pública. Não se deve, portanto, correr o risco de cair num discurso apologético de "fim de tudo" - da razão, da ciência, da verdade, da história etc. - assim como de fazer uma interpretação constatativa do real (Goergen 2001).

Mesmo assim, espero ter conseguido trazer a relevância do debate e de certas críticas e mudanças que vêem ocorrendo para que também não iluda com certos alicerces da modernidade, pois esta, em muitos aspectos, representa sobretudo o ideal liberal-burguês de sujeito, com seu modo de produção capitalista, sua ciência positiva, e suas instituições políticas sociais eficientes e capazes de perpetrar suas formas de dominação e controle historicamente conhecido desde o processo colonizatório da América.

Entretanto, emerge do pensamento pós-moderno em educação uma contradição intrínseca. Se, por um lado, ele procura criticar as formas de poder existentes e "relativizar" a supremacia de certos discursos dominantes - de homem, europeu, branco, heterossexual, trabalhador, etc. -, por outro, corre o risco de impedir a crítica de determinadas estruturas sociais consolidadas as quais mantêm o status quo educacional desta forma desigual. Silva (1993:135) sintetiza claramente isto, nas palavras a seguir:

O pós-modernismo pode ser útil para um projeto educacional crítico na medida em que nos torna conscientes a respeito dos efeitos de verdade de todos os discursos, mas pode ter também consequiências regressivas e conservadoras quando essa desconfiança em relação aos discursos e ao caráter ilusório de todos os discursos nos impede de fazer uma critica de estruturas sociais que são bem reais e concretas...

Faz-se necessário, portanto, tomar o pensamento pós-moderno sob a "função" de interpretar criticamente a modernidade, sem perder de vista a necessidade de assegurar a historicidade da condição humana e de que é somente através da práxis que o homem pode transformar a realidade.

\subsection{A atmosfera da crise e a ordem cultural pós-modernista}

Cabe ainda ressaltar sob quais bases pode-se considerar a ordem do discurso cultural pós-modernista. Teóricos afirmam que, embora as primeiras menções com este termo 
remontem às primeiras décadas do século $\mathrm{XX}^{12}$, é seguramente a partir do pós-guerra período que Hobsbawm (2003) nomeia de a "Era do Ouro" - que o termo é absorvido pelos diversos meios acadêmicos, intelectuais e artísticos para designar as inúmeras transformações em processo no Ocidente. O autor é categórico ao defender que, com o fim da II Guerra Mundial, as nações desenvolvidas da Europa, da América do Norte, além de uma pequena faixa de ricos e cosmopolitas em toda parte, viram transformações da mais impressionante e profunda rapidez e universalidade que a história tem registro.

A euforia da Era do Ouro, segundo o autor, foi celebrada, dentre várias características, pelo investimento e planejamento estatal da economia, intervenção e regulação do livre mercado e oferecimento e garantia das necessidades básicas à população destes países (educação, saúde, moradia, aposentadoria, etc.); e pelo pleno emprego, consumo de massa e acesso aos bens de consumo pela classe média de produtos antes considerados de luxo e de elite. Viu-se também a sociedade ocidental desenvolvida se tornar cada vez mais consumista e hedonista, a cultura se transformar num bem de consumo e o consumo se tornar um bem cultural, viu-se a morte do campesinato, a explosão do acesso aos níveis superiores de ensino, a reorganização do modelo familiar com a mudança do papel da mulher e a construção de uma nova juventude que buscava construir sua identidade muito mais nas diferenças de classe (principalmente as classes altas que recorriam aos valores operários) do que de geração, o que criava certo abismo cultural entre a geração anterior e aquela que se formava. Enfim, a geração que se formava a partir dos anos 60 não vira a miséria social produzida pela Grande Depressão nem tampouco as atrocidades políticas dos regimes totalitários e os atrozes horrores das duas grandes guerras. Suas insatisfações não eram, pois

amortecidas pela consciência de ter vivido épocas de impressionante melhoria, muito melhores do que seus pais algum dia esperavam ver. Os novos tempos eram os únicos que os rapazes e as moças que iam para a universidade conheciam. Ao contrário, eles sentiam que tudo podia ser diferente e melhor, mesmo não sabendo exatamente como".(Hobsbawm, 2003:295/6)

Foi nessa atmosfera política do Estado do Bem-Estar social, da assertividade cada vez maior de que o sistema econômico capitalista triunfaria diante do socialismo e de que o consumo era um "direito" de todos que aceitassem as regras do livre mercado, que emergiu o discurso pós-modernista como forma afirmativa de que o mundo estava mudando. Foi neste boom de mudanças que jovens estudantes, intelectuais, acadêmicos e artistas de vanguarda e

\footnotetext{
${ }^{12}$ Cf. Featherstone (1995), Harvey (1999).
} 
profissionais ligados à indústria e produção cultural - aquilo que Bourdieu (In Featherstone, 1995) chamou de novos intermediários culturais - procuraram, e segundo Featherstone (1995) ainda procuram, oficializar o termo.

De outro lado, ainda na gênese histórica do pós-modernismo, tem-se a partir de meados da década de 50, uma crise no campo intelectual de esquerda configurada, pelas desesperanças político-emanipatórias do regime comunista soviético, e pelo desencanto resultante pelo fracasso político gerado pelos movimentos estudantis pós-68. Della Fonte (2004:3 mimeo) afirma que naquele momento "a esperança de revoluções mundiais se esvaziou, o descrédito incidiu sobre a militância política, sobre os projetos coletivos de emancipação".

Nesse sentido, a autora, ao alertar para a correlação da emergência do discurso pósmoderno com a "biografia da esquerda no Ocidente", leva a pensar que o germe embrionário do pensamento pós-moderno é produto de uma consciência formada numa fase de extrema prosperidade capitalista e da derrocada do pensamento de esquerda-marxista e do socialismo "real".

Cabe então esclarecer a não casualidade no fato de o uso do termo pós-modernismo ter tomado corpo no período histórico de euforia do capitalismo - a partir da década de 60 , atingindo seu ápice nos anos 70 e $80^{13}$. Quer dizer, não se pode destituí-lo de sua historicidade e do seu caráter ideológico, significando, portanto, ser ele fruto de um, ou vários discursos engendrados numa atmosfera artístico-cultural-acadêmica específica que se sustenta na medida em que se revela a base material em que ele é produzido (Featherstone, 1995 e Jameson, 1996). Featherstone (idem:68) valida o termo, mas não deixa de nos alertar para que se leve em conta as disputas e

\footnotetext{
processos de competição, monopolização, desmonopolização e usurpação, as várias estratégias dos marginalizados e dos dominantes, que ocorrem entre os diferentes grupos especialistas na produção simbólica, nos quais o termo 'pós-modernismo' se converte num trunfo, na disputa entre grupos.
}

Além de se considerar $o$ que se está falando sob a tutela do discurso do pósmodernismo, é necessário verificar quem está falando por ele. Desde Foucault (1996) pelo menos, sabe-se das relações imbricadas entre saber e poder e, neste caso, ele não só não é exceção, como é preciso identificar as bases, percursos e conseqüências ideológicos na disputa pela autoria e singularidade deste termo controverso.

\footnotetext{
${ }^{13}$ Cf. Featherstone (1995), Jameson (1985), Smart (1993) e Harvey (1999).
} 


\subsection{Apontamentos preliminares - continuidades e rupturas}

Como o leitor deve perceber, não se trata aqui nem de assumir nossa marcha à pósmodernidade, nem a permanência aos ideais modernos, mas sim de se incrustar na encruzilhada deste debate, apontando a relevância da crítica radical da modernidade colocada à ordem social contemporânea e analisar histórica e culturalmente os caminhos e propostas, com seus riscos e consequiências à educação e às escolas brasileiras de hoje.

A possibilidade de ascensão de um pensamento social crítico da modernidade significa necessariamente relacioná-lo aos grandes eventos históricos deste último quarto do século $\mathrm{XX}$, ou seja, a derrocada do socialismo real, a globalização e as estratégias políticoeconômicas neoliberais. Significa também considerar o impacto de três elementos centrais na história ocidental deste período: a crescente importância assumida pela racionalidade tecnocientífica na vida social e suas conseqüências desiguais; o desencantamento com uma revolução socioeconômica capaz de levar à humanidade melhores e universais condições de vida; e o questionamento da razão pela qual civilizações ocidentais outorgaram a si o direito de ter a sua cultura, a sua ciência e a sua racionalidade como discurso de validade universal (Smart, 1993:114).

Sob uma lente mais fechada, vale demarcar que esse movimento, denominado muitas vezes de pós-modernista, se refere à cultura e à ideologia social contemporâneas e que, muitas vezes, corresponde à adesão a modos de vida cultural de determinados segmentos da sociedade - estetização da vida cotidiana, estilos de vida urbana, sociedade do consumo, cultura como superficialidade, apagamento da fronteira entre real e imagem, etc. Deve-se, portanto, ter o cuidado em não se filiar a um discurso pós-modernista que esteja inserido naquilo que Bourdieu (in Featherstone, 1995) chamou de habitus da pequena nova burguesia - a nova classe média - preocupada em expandir e legitimar suas próprias disposições e estilos de vida específicos (Featherstone, 1995). Paradoxalmente, para Giroux (1993:52), é este discurso, muitas vezes, que busca atacar aquela elite intelectual que se arroga ser a vanguarda emancipatória, que julga estar acima da história apenas para tentar moldá-la através de suas pretensões sociais. Por ora, então, sigo novamente Jameson (1996:29) quando, numa observação atenta, afirma que "qualquer ponto de vista a respeito do pós-modernismo na cultura é ao mesmo tempo, necessariamente, uma posição política, implícita ou explícita, com respeito à natureza do capitalismo multinacional em nossos dias". 
A pergunta que se coloca é a seguinte: terá o pós-modernismo um potencial revolucionário em virtude de sua oposição a todas as formas de metanarrativas e da sua estreita atenção a outros "modos de vida" a "outras vozes" antes silenciadas? Ou ele não passa da comercialização e domesticação do modernismo e de uma redução das aspirações já prejudicadas deste a um ecletismo de mercado "vale tudo", e marcado pelo laissez-faire? Ele solapa a política neoconservadora ou se integra a ela (Harvey, 1999)? Responder à envergadura destes questionamentos está além do limite acadêmico de um trabalho como este. Na verdade, além deste "limite", vale levar em consideração que a seriedade e profundidade do debate têm atraído intelectuais, escritores, artistas de diversas áreas do saber, do conhecimento. Qualquer tentativa de esgotar ou fechar o assunto seria pura pretensiosidade.

Em síntese, pode-se assim considerar a crítica da modernidade: numa primeira hipótese, pela idéia de continuidade ou, no máximo, radicalização da modernidade, afinal continuamos dentro do sistema capitalista e os modos de produção da vida social não se alteraram estruturalmente. Em uma segunda hipótese, para indicar uma quebra, uma ruptura radical com as bases e condições da modernidade, ou seja, com as formas de realização da vida social, do conhecimento, das artes e da moral, pois não correspondem mais ao ideal universal racional de homem. Na terceira, como uma idéia que indica mudança nas formas como experimentamos e nos relacionamos com o pensamento moderno. Mudou a forma ${ }^{14}$, como olhamos para a modernidade. Como alerta Rouanet (2000), a existência de uma consciência de ruptura, não necessariamente significa uma ruptura real; uma vontade de mudança, não quer dizer que ela ocorra de fato. Entretanto, o exercício crítico de questionamento das bases que sustentam os pilares da modernidade, de certa forma, é a manifestação de sua própria crise.

Fico assim com uma proposição de Goergen (2001:27), com relação ao pósmodernismo quando afirma que não cabe negar

em princípio e de forma global, suas teses, mas analisá-las criticamente com o objetivo, inclusive de aproveitar para o campo da teoria educacional os aspectos de sua crítica à modernidade que desvelam faces aporéticas da racionalidade iluminista e ajudam a compreender certas tendências do desenvolvimento histórico contemporâneo.

Seguimos agora à investigação de como a crise da modernidade e o seu pensamento crítico interferem e afetam o plano educacional em geral e as escolas em particular, por um

\footnotetext{
${ }^{14}$ Aquilo que Giddens (1991:45) chama de caráter reflexivo da modernidade. Para ele, "a reflexividade da vida social moderna consiste no fato de que as práticas sociais são constantemente examinadas e reformadas à luz da informação renovada sobre estas práticas".
} 
lado, e como estas últimas, através da pesquisa empírica em uma escola de Ensino Fundamental de São Paulo, têm produzido respostas aos discursos, práticas e ações instituintes deste debate no que tange a linha que compõe e constitui a forma e a identidade de seu próprio currículo. 


\section{Capítulo II - Ideais pedagógicos modernos, história e sistema de ensino brasileiro}

Antes propriamente de aproximar a lente sobre a vida da escola investigada, tratarei de colocar em debate a formação histórica da instituição escolar na modernidade, seus ideários e correntes pedagógicos mais influentes e a constituição do processo de modernização da escola brasileira. Isto se faz necessário, primeiramente, para que não se incorra a pensar a escola pesquisada fora de um contexto sociohistórico mais amplo. Outra razão corresponde à importância de vincular as correntes pedagógicas historicamente predominantes no cenário educacional brasileiro à própria efetivação modernizadora do "projeto" nacional de educação e escolarização. Neste sentido, não se pode correr o risco nem de deixar a escola "flutuando" em um tempo-espaço puramente próprio e particular, nem mesmo vir a crer que a modernização brasileira (e quiçá sua pós-modernização) se dê de forma correlata e correspondente com as inquietações e encruzilhadas provenientes daqueles que de fato constituíram o debate no mundo ocidental.

Por conseqüência, isto significa traçar uma análise que contemple, inicialmente, uma breve análise do contexto sociohistórico europeu em que surge a escola e as idéias pedagógicas subjacentes, seguindo então para as formas de embate e constituição da relação teoria-prática educacional, idéias-ações pedagógicas no cenário nacional do século XX. Somente a partir desta breve digressão será possível penetrar na análise empírica dos dados coletados no estudo de caso e estabelecer ligações/relações entre os processos de modernização, a escola brasileira/paulistana e suas ações educacionais e pedagógicas, sobretudo na questão referente ao seu currículo.

\section{Educação e escola no "projeto" da modernidade}

Se tomando por base a modernidade em crise e, por conseqüência, considerando a escola uma instituição eminentemente moderna, pode-se assim, se não afirmar que a escola está em crise, que ao menos, a crise do pensamento moderno passa por ela. Veiga-Neto (2003:109), radicalizando esta proposição interroga: "se a escola moderna esteve sempre implicada na constituição da modernidade e se, agora, é a própria modernidade que está em crise, qual o futuro da escola?"

Embora não seja a intenção fazer neste momento uma incursão histórica da constituição da instituição escolar dentro do projeto da modernidade, é necessário, lançar mão 
dos ideais modernos constitutivos da noção de infância e consequentemente deste projeto de sociedade através da instituição escola.

Sabe-se que, embora seja com as mudanças no mundo do trabalho, com a industrialização européia do século XVIII que a escola busca assumir seu caráter público e universal, é antes com o ratio studiorum, com os métodos pedagógicos jesuíticos, já no século XVI e XVII que a sistematização do processo de escolarização toma seu primeiro e grande impulso moderno.

Está entre alguns dos grandes ideais modernos a concepção de que todo ser humano é portador do direito à educação e a realização desta pela escolarização. Em contrapartida, as sociedades industriais européias atribuíram à instituição escolar a responsabilidade pela formação, pelo cuidado, pelo controle e pela disciplinarização, por um lado, e pela manutenção da tradição, do passado e da cultura historicamente acumulada, por outro, daqueles que estavam na fase da infância e juventude. Papéis antes reservados, sobretudo, à família e à igreja.

Já é bem compreendido e constituído pela Pedagogia, a idéia de que educação, formação e conservação do homem - sua espécie e sua cultura - estão estritamente vinculados. Uma das principais tarefas da educação institucionalizada é, portanto, assegurar aqueles que vêm ao mundo, através de um processo socializador da cultura, a institucionalização de suas condutas e a manutenção do passado e das tradições. A educação escolarizada moderna, embora não somente, tem a função central de ligar o indivíduo às suas raízes e tradições - o passado - e a cultura objetivada - o presente. Por isso Arendt (1992) enxerga na educação seu caráter conservador, pois é do passado do homem - suas experiências, aprendizados e conhecimentos - que surge a conservação do mundo e por conseqüência, a própria atribuição de sentido possível, dada ao presente.

Retomando a proposta de Santos (1995), de que a modernidade se constituira sob os pilares da regulação e da emancipação, considera-se aqui valioso analisar a constituição do ideário moderno de infância, educação e escolarização calcado nesta dualidade.

Nesse sentido, ao resgatar o legado moderno à educação, a partir das considerações objetivas de Kant (1999:25/26) vê-se as primeiras pistas do que viria a ser o "projeto" educacional escolar. Para o filósofo, através da educação, o homem deveria tornar-se: disciplinado, impedindo-se que a animalidade se estenda à humanidade; culto, para isso servem a instrução e o ensino; prudente, para que seja querido e influente; e por fim, moralizado, atributo capaz de fazê-lo saber julgar e escolher o certo e o bem. Acrescenta-se a isso que é através da escola e da educação pública que o homem seria lançado em um estágio 
de vida mais evoluído - a maioridade - formando uma sociedade de cidadãos livres e autônomos, capazes de aprender a tolerar-se, cooperar-se, sem se barbarizar. Este é passo essencial para participar da vida e do espaço público. Isto ocorre porque o processo educacional leva o homem, no caso, a criança, de sua animalidade, amoralidade, irracionalidade, para o estatuto de adulto, realmente humano, pois constituiu suas faculdades morais através do uso da razão (Gagnebin 1996, Veiga-Neto 2003:104/5).

É nesse sentido que Libâneo (1996:133) afirma que o século XVIII traz consigo um grande otimismo civilizatório, pois representa o "ideal de formação da personalidade plena, da educação integral, fundada na razão universal, é cheio de otimismo quanto à possibilidade de produzir um mundo melhor mediante a educação da juventude."

Para Gagnebin (1996:86) reside nesta visão moderna cartesiana de infância a sustentação da necessidade de se constituir um espaço político-público, calcado no logos:

Essa criança ameaçadora na sua força animal bruta, essa criança deve ser domesticada e amestrada segundo normas e regras educacionais fundadas na ordem da razão $(\log o s)$ e do bem tanto ético quanto político, em vista da construção da cidade justa.

Em seguida acrescenta a autora (1996:91) que a infância é o

território perigoso das paixões, do pecado e do erro, zona escura sem os caminhos que traçam as palavras e que ilumina a razão, ela é, no entanto, na nossa miséria humana, o único solo à disposição de onde possa brotar, naturalmente, essa mesma razão que lhe falta. (...) Cabe à educação/formação realizar esta potencialidade e transformar esse pequenos egoístas, tirânicos e choraminguentos em homens dotados de linguagem, isto é, capazes de pensar e agir racionalmente, de se tornarem os cidadãos responsáveis e independentes de uma res pública.

Este paradoxo na qual se constitui a representação cartesiana de infância na modernidade, pois a criança é a ameaça e a promessa da constituição ser adulto racional, é invertido, segundo Gagnebin (idem:91), por Rousseau ao propor "desconfiar da razão e confiar ilimitadamente na natureza" e no sentimento humano. Nesse sentido, a versão pedagógica de Rousseau se desloca para a defesa da natureza pura e do sentimento da criança, que felizmente não foi ainda corrompido pelo pervertido mundo das convenções sociais adultas. O ideário pedagógico rousseauniano se impregna de respeito e proteção à fase infantil, pois reside nela a essência boa da natureza humana, atribuindo à escola o espaço privilegiado de desenvolvimento prolongado destas faculdades. 
Sacristán (1999:149), baseado nas proposições kantianas, avança no debate ao apontar que o legado (incompleto) da modernidade para a educação se constituiria por quatro proposições. A saber: a reprodução ou transmissão da cultura objetiva ou o que outros chamam de patrimônio histórico-cultural da humanidade - indivíduo culto; o desenvolvimento da personalidade do indivíduo imaturo - personalidade adequada; socialização aos valores compartilhados e adequados - o bom cidadão, autônomo e racional; a preparação para tornar o indivíduo um ser produtivo - o bom trabalhador. Tais elementos se sustentariam por um princípio comum, a saber, a idéia de universalização desses bens sob condições de igualdade, e que está, por fim, atrelada à idéia de progresso da e para a humanidade. A educação seria, portanto, o grande motor capaz de levar o homem de uma condição de barbárie, ignorância, dogmatismo, dominação e retrocesso, para um futuro sustentado na civilidade, racionalidade, maioridade, autonomia e progresso. Como resultado, segundo Sacristán (1999:12),

entre as modernas convicções que regeram a educação está a crença e a esperança de que as políticas, os currículos, as instituições e as práticas pedagógicas poderiam colaborar ordenadamente a obter de maneira racional, fins seguros de validade indiscutível.

O cumprimento desta tarefa pela educação, através da instituição escolar, se relaciona intrinsecamente à emergência, nos séculos XVIII e XIX, dos conhecimentos científicos preocupados com as diversas manifestações do humano - psicologia, pedagogia, sociologia, antropologia, biologia, etc. A busca em explicar a funcionalidade do sujeito em suas múltiplas dimensões abre espaço para a constituição de novos profissionais, dedicados a ordenar e explicar tais fenômenos. Nesse sentido, não por acaso, o desenvolvimento da infância (e juventude), o fenômeno educativo, as relações pedagógicas escolares e a própria formação do sujeito moderno se constituem como objeto de reflexão das Ciências Humanas de forma a atribuir-lhes ordenação e veracidade, quer dizer, a visão científica trazendo a idéia de que tais fenômenos seriam regidos por leis que permitissem algum tipo de regulamentação e controle externo (Sacristán, 1999:170) e de que os conhecimentos produzidos pudessem ser universalmente seguros e verdadeiros. De alguma forma então, estes conhecimentos científicos como forma de se constituírem, encontraram no "objeto infância" uma base para seu desenvolvimento, ou indo além, nos dizeres de Fernandes (1996:63) estes conhecimentos científicos para surgir contraíram "uma dívida de fundação com ela".

Sacristán (1999:171) sintetiza esta tarefa nestes longos dizeres: 
Uma missão como a escolarização, tão importante para o indivíduo e para a sociedade, na era em que o conhecimento pretende controlar toda a atividade como manifestação de fé na razão científica, não podia ser deixada para improvisação (...). Em consonância com um sujeito que se desenvolve, que aprende de maneira progressiva, será situada a busca de uma ordem progressiva e coerente no processo que o leve a essa apropriação. O sujeito da modernidade é orientado por um eu ordenado; (...) A meta desse processo ordenado deve ser a independência do sujeito, que toma em suas mãos o próprio destino, livre e autônomo, que é guiado reflexivamente no mundo aberto e submetido à constante revisão.

Entretanto, o debate filosófico se reordena a partir da feroz crítica feita por Foucault (2000) às formas de opressão e controle da subjetividade gestada pela escola, assim como por outras instituiçõos modernas - as forças militares, as prisões, os hospitais, etc. Quando o autor afirma que "não existe nenhuma relação de poder sem uma correlativa constituição de um campo de conhecimento, nem qualquer conhecimento que não pressuponha e constitua ao mesmo tempo relações de poder" (idem: 27) está a dizer que na gênese da constituição do sentido e das práticas escolares, coexiste formas de dominação e controle de corpos e mentes - através de inúmeros dispositivos disciplinares - e produção de saberes sobre os mesmos, o que leva à ambivalência a respeito da idéia de disciplina e poder, pois são forças que tanto produzem o sujeito moderno como também o aprisionam e o oprimem.

Nesta linha foucaultiana, Veiga-Neto (2003:107) alerta para o fato de que nem todas as práticas que se dão na escola foram feitas para que as crianças de fato aprendessem melhor. Antes de funcionar para a melhoria da aprendizagem, a escola moderna funcionou e funciona para fabricar novas formas de vida e regimes de verdade.

Tais compreensões a respeito de quais são as idéias pedagógicas e significados da escola emergentes com a modernidade mostram a conflituosa dicotomia indivíduo $\mathrm{x}$ sociedade, necessidades para a formação do sujeito x necessidades para a reprodução cultural, respeito à subjetividade x normatização das ações e imposição de regras aos indivíduos (Sacristán, 1999:168).

O grande desafio colocado à educação e à escolarização moderna é, para Sacristán (1999:173), equilibrar e compatibilizar um legado que impôs regras, esforços, disciplinarização no processo formativo do sujeito à possibilidade de exercer liberdade e autonomia individuais enquanto ocorre este processo. A certeza de que pela educação o sujeito moderno poderia se emancipar, já não carrega a mesma certeza de tempos atrás. Ao analisar como as mudanças políticas, econômicas e sociais desta virada de século e milênio impõem novas tarefas à escola, Libâneo (1996) se interroga se "ainda é possível acreditar que a escola seja o lugar de desenvolvimento da razão humana, base para a liberdade intelectual e 
política?". O autor considera que sim, porém que não se poderão ignorar os questionamentos e mudanças na ordem epistêmica e ética colocados pelo pensamento pós-moderno.

\section{Modernização, idéias pedagógicas e sistema de ensino na América Latina}

Antes de entrar diretamente no desenvolvimento do pensamento pedagógico brasileiro, cabe contextualizar os vínculos históricos dos processos de modernização social e educacional em uma perspectiva latino americana.

O século XIX traz ao cenário político latino americano a ruptura com mais de três séculos de exploração, dominação e subjugação que os povos nativos desta larga região haviam sido submetidos. Sabe-se que, mesmo com o estabelecimento do livre-cómercio, os movimentos de independência política, sobretudo, em relação à Espanha e Portugal, não geraram elevados graus de emancipação social e econômica destas nações recém constituídas. Mesmo assim, este processo levou a cabo o desenvolvimento do projeto burguês-liberal de nação influenciando assim, não só os ideais pedagógicos constituintes em toda a região como também a estruturação e organização dos seus sistemas de ensino.

Mesmo correndo o risco de simplificar demais as particularidades e idiossincrasias da história dos distintos países latino americanos, pode-se de forma sintética, afirmar que no século XIX, sobretudo em sua segunda metade, os movimentos liberal-progressistas buscaram, do ponto de vista político, separar o Estado da Igreja, o que significava, no âmbito educacional, retirar do poder eclesiástico, o monopólio e o controle das formas de ensino oferecidas às elites européias e mestiças (criollas) nacionais. Dessa forma, mesmo com uma enorme massa de excluídos, a educação surge como um direito de todos os cidadãos e um dever do Estado. A política educacional liberal-burguesa latino americana, de modo geral, se traduzira, segundo Oscaris e Jiménez (1995) através da estatização do ensino primário, sua

laicização, gratuidade e obrigatoriedade. É evidente que estes princípios não se deram de forma efetiva e universal nestes países como conclamava tal ideário até porque é sabido dos próprios limites políticos e econômicos que o projeto burguês de modernização se impunha como forma de subsistir. O que importa aqui é, como se afirmou, atentar para os processos incipientes de modernização social destes países e sua correlação com as idéias pedagógicas e com o sistema de ensino.

O rechaço à atuação da Igreja na educação nacional trazia consigo não só a crítica ao modelo escolástico de ensino, como abria imenso espaço à influência do cientificismo positivista em ascensão na Europa. Por conta disso, de acordo com Oscaris e Jiménez (1995), 
a instrução científica, entendida como o estudo das ciências naturais e da matemática, assim como a exigência de um pensar mais racional e ativo, começa a ser assumida pelas principais lideranças políticas latino-americanas como aplicação de ideais liberais progressistas. Assim, a valorização do ensino das línguas modernas (em contraposição ao latim), o fim dos maus tratos corporais e a preocupação com a mínima qualidade dos professores despontam como preocupações de ordem político-pedagógico por parte da maioria dos governantes, sobretudo a finais do século XIX.

O início do século XX latino americano foi marcado já pela consolidação da burguesia liberal como classe dirigente capitalista e pela influência norte-americana nos rumos econômicos destes países. Por conseqüência, as idéias pedagógicas que despontavam na Filosofia da Educação eram de cunho pragmatista e a escola tinha que, de alguma forma, legitimar os interesses da classe dominante. Participação ativa por parte do educando, partir dos conhecimentos experienciais dos mesmos e compreensão de que escola e vida democrática eram faces de uma mesma realidade, propondo uma visão de educação conciliadora das diferenças de classe iam de encontro à estabelecida visão herbatiana passiva do ensino. A idéia escolanovista de fazer da instituição de ensino a "realização" da vida democrática, de alguma forma, levava a conformação ou aceitação daquela hierarquia social constituinte ao mesmo tempo em que "reformava" o modelo de ensino "tradicional".

Para Oscaris e Jiménez (1995), na primeira metade do século XX, setores importantes do magistério latino americano buscaram organizar através do investimento na educação, formas de resistência política às mazelas conseqüências do capitalismo imperialista e do domínio burguês liberal. Argumentam assim (idem:126), que o magistério do continente se esforçou por

\footnotetext{
elevar seu nível de organização continental, defender a democracia educacional e cultural, incrementar sua qualidade profissional, praticar a solidariedade internacional e defender os princípios de escolas para todos, com matrícula gratuita no setor público...assim como o direito de todos a ter acesso ao ensino e a necessidade de erradicar o pior mal cultural da América, o analfabetismo.
}

Mesmo com a urgência dessas questões, a superação desses desafios se mostrou, ao longo do século XX, de difícil transposição. Ao passo que diversas lideranças políticoeducacionais lutavam para levar a cabo os princípios da "educação popular" - entendida como o conjunto de idéias e práticas pedagógicas preocupadas com a democratização e qualidade do ensino para as grandes massas trabalhadoras excluídas do universo do poder, consumo e 
liberdade - a tarefa de estruturar e gerir o sistema público de ensino coube ao Estado republicano destes países. Salvo as inúmeras e distintas características nacionais, o que se viu do desenvolvimento do ensino público-estatal, de modo geral, foi a centralização (muitas vezes autoritária), inchaço e burocratização de sua administração de forma mais a manter os interesses e privilégios da classe dirigente do que propriamente a democratizar o ensino às crescentes massas populares. Neste sentido, as últimas décadas do século XX puseram como preocupação central à educação público-estatal lidar com a capacidade de ofertar, administrar e gerir o sistema de ensino sob a intensa pressão do neoliberalismo, expressada na "desresponsabilização" do Estado ao direito à educação básica, pela lógica administrativa descentralizadora e muitas vezes privatizante do sistema de ensino e pela radicalização da idéia de autonomia de gestão, que muitas vezes se vê traduzida em precariedade e abandono do próprio sistema.

Estes fatores levaram o sistema educacional dos países latino americanos, a exceção de Cuba, a uma situação estrutural alarmante. Ensino elitista (tanto em termos de acesso quanto de configuração do próprio currículo escolar) x ensino massificado e precário; altas taxas de analfabetismo; fenômeno do fracasso escolar traduzido em altos números de evasão; falta de estrutura material e pedagógica das escolas públicas; baixos salários e formação docente deficiente, entre outros, figuram entre os principais aspectos que constituem o “quadro" institucional dos sistemas públicos de ensino na América Latina.

De modo geral, o sistema de ensino latino americano, sobretudo nos últimos 50 anos, foi capaz de expandir o acesso à educação básica aos setores sociais historicamente excluídos. Entretanto, as mudanças em níveis qualitativos de ensino - entendido ao menos como o cumprimento do que se propõe como sua própria finalidade - não correspondeu às inúmeras demandas sociais, proveniente dessas classes sociais recém-chegadas ao processo de socialização e ensino escolar. Como consequiência, os sistemas educativos latino-americanos, ao expandir a cobertura do "direito" à educação à praticamente todos os setores sociais sem o acompanhamento de modificações na estrutura e conteúdo de ensino, deslocou a questão da exclusão social, que antes se configurava entre escolarizados e não escolarizados, para o interior dos sistemas de ensino (Nassif, Rama e Tedesco 1984). O grande elemento complicador segundo Nassif, Rama e Tedesco (1984:121) foi que "a ampliação educacional se realizou oferecendo basicamente o mesmo modelo de educação das elites às massas, mas sem sua qualidade e profusa informação cultural”.

\section{Pensamento pedagógico brasileiro e modernização escolar}


No que tange a constituição do sistema de ensino brasileiro, tomar-se-á como base os estudos de Dermeval Saviani (1997a, 1997b), os quais assinalam para o fato de que o processo de escolarização nacional pós-independência política de Portugal buscou acompanhar o ideário burguês liberal, o que significava sustentar a idéia de que a educação escolar era o instrumento modernizante-emancipador da sociedade brasileira recém "liberta" das amarras sociais coloniais.

Por conseqüência, educação e escola foram historicamente compreendidas como os instrumentos capazes de superar, na construção política do "Brasil moderno", os problemas sociais provenientes do desenvolvimento desigual da sociedade capitalista. Segundo o autor (Saviani 1997a:16), neste caso, a educação seria interpretada de forma não crítica, portanto, como "uma força homogeneizadora que tem por função reforçar os laços sociais, promover a coesão e garantir a integração entre todos os indivíduos no corpo social”.

Nesse sentido, a escola brasileira, na virada do século XIX para o XX, era entendida como o veículo social legítimo e capaz de transmitir o conhecimento socialmente adquirido, o que pressupunha uma pedagogia calcada na autoridade moral e científica do professor e no acompanhamento passivo e disciplinado de seus alunos. A chamada pedagogia tradicional concebia assim, a marginalidade produzida a partir do processo de socialização como um desvio que a escola podia corrigir se "atacasse" corretamente a causa do problema.

Compartilhando da mesma concepção de relação escola-sociedade e da causa da marginalidade, porém intervindo de forma inversa na resolução desta problemática pedagógica, o chamado escolanovismo, é segundo Saviani (1997a:19), a corrente pedagógica que ganha força a partir do início do século XX, por propor um deslocamento da questão do conhecimento, da capacidade cognitiva para a da conduta humana. $\mathrm{O}$ que difere as pessoas não é mais a quantidade de conhecimentos adquiridos, mas a capacidade que os indivíduos têm de se relacionar socialmente, melhor se adaptando ao meio social e aos conjuntos de valores. Em termos concretos, a pedagogia da "Escola Nova", procurava transformar internamente a escola tradicional de forma a colocar o aluno no centro da relação do ensinoaprendizagem, e fazer do ambiente escolar interno, o mesmo necessário para o ambiente social democrático externo.

Entretanto, o que se viu no processo histórico de "adaptação" dessa corrente pedagógica foi a constituição de escolas experimentais, bem equipadas, com poucos alunos, de alto nível econômico, elitizando a demanda social, ao passo que se manteve o sistema tradicional de ensino para as grandes massas de trabalhadores. Como se sabe, a Escola Nova e 
suas proposições pedagógicas, também se mantém presentes no ideário pedagógico nacional atual, se deparando com dificuldades de implementação devido a incompatibilidade com as condições reais do sistema de ensino público nacional. Para Saviani (1997a:22), ela trouxe mais conseqüências negativas do que positivas, uma vez que

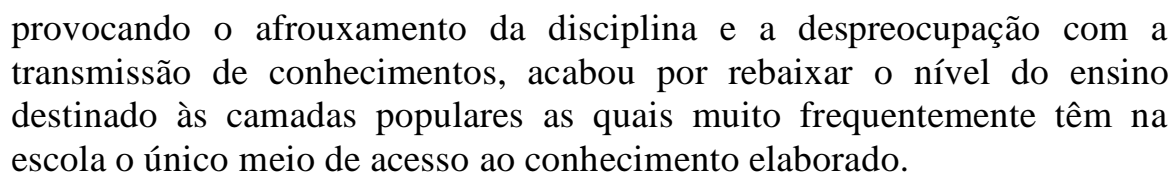

A outra teoria pedagógica não crítica que Saviani (1997a) assinala, surge a partir do próprio processo de industrialização nacional que se intensifica em meados do século XX e que terá como objetivo fundamental, fazer da educação e da escola, agentes sociais eficazes e competentes do ponto de vista produtivo. Esta pedagogia tecnicista, portanto, se preocupa em superar certos limites da pedagogia nova, na medida em que buscar adaptar o sistema escolar ao sistema fabril; o mundo da vida democrática para o mundo do trabalho. Em outras palavras, um bom ensino, o que não marginaliza é aquele que produz um bom trabalhador, competente e eficaz diante dos desafios postos pelo sistema produtivo. Assim, (Saviani 1997a:25/26), "se para a pedagogia tradicional a questão central é aprender e para a pedagogia nova é aprender a aprender, para a pedagogia tecnicista o que importa é aprender a fazer".

Em contrapartida, para além das teorias da educação não críticas, Saviani (1997a) aponta para as teorias da educação crítico-reprodutivistas, e assim as chama, pois entende que elas têm como finalidade última, não a superação da desigualdade, da marginalidade, da anomia, mas sim, evidenciar que a educação não pode ser entendida fora dos condicionantes sociais e que, portanto, ela tem como função reproduzir tal desigualdade, se o sistema social for desigual. Neste sentido, estas teorias da educação procuram apenas analisar e criticar os instrumentos e recursos sociais que têm garantido a reprodução da marginalidade, na medida em que vivemos em uma sociedade estruturada pela luta de classes e pela exploração de uma classe sobre outra. Para isso, o autor traz à luz da reflexão as teorias do sistema de ensino enquanto violência simbólica, de Bourdieu e Passeron ${ }^{15}$, a teoria da escola enquanto aparelho ideológico do Estado de Althusser ${ }^{16}$ e a teoria da escola dualista de Baudelot e Establet ${ }^{17}$, buscando assim demonstrar que para tais correntes o sistema de ensino é o elemento, o

\footnotetext{
${ }^{15}$ Cf. Bourdieu e Passeron. A reprodução: elementos para uma teoria do sistema de ensino. RJ, Francisco Alves editora, 1975.

${ }^{16}$ Cf. Althusser, L. Ideologia e aparelhos ideológicos do Estado. Lisboa, Editorial Presença, s.d.

${ }^{17}$ Cf. Baudolet, C. e Establet, R. L’école capitaliste en France. Paris, François Maspero, 1971.
} 
instrumento, o aparelho social que se utiliza de determinados recursos, seja a violência simbólica, seja a ideologia, para garantir a reprodução da desigualdade.

Por fim, como forma de superação desta concepção presa ao reprodutivismo, Saviani (1997a) propõe como alternativa teórico-prática, a teoria histórico-crítica da educação. Para esta teoria é exatamente pelo fato de que educação e sociedade não se dissociam, se (re)produzindo no seio da dinâmica social que a educação e seus sistemas de ensino podem intervir e transformar a realidade social. É exatamente por a escola estar inserida nos modos de reprodução da sociedade capitalista, que aquela (a escola) pode e deve interferir nos rumos gerais desta (a sociedade) através do trabalho escolar.

Para tanto, a escola deve funcionar como instrumento social que viabilize a constituição de uma sociedade sem classes - socialista - o que ocorreria necessariamente a partir do compromisso do trabalho escolar com a verdade, ou seja, com a transmissão do conhecimento objetivo socialmente necessário para desvelar os mecanismos ideológicos da sociedade liberal-burguesa (Saviani 1997b, Duarte 2001). A escola, assim, ainda em uma sociedade capitalista, para além de reproduzir e perpetrar os interesses da classe dominante, é considerada como instituição social e histórica capaz de aprofundar as contradições do sistema capitalista, a saber, "o desenvolvimento cada vez mais socializado das forças produtivas e a apropriação privada tanto dos meios de produção como dos produtos dessa produção" (Duarte 2001:5), de forma a abrir caminho no seio material para a superação deste próprio modelo de sociedade.

A teoria educacional histórico-crítica procura por em questão, evidenciar as contradições do sistema capitalista e a ideologia liberal-burguesa em sua manifestação no trabalho escolar, e propõe como forma de superação a construção de uma escola unitária baseada na filosofia da práxis, na qual desenvolva a formação completa dos indivíduos, tornando-os capazes de ver e agir para além dessas contradições e domínio ideológico. Isto ocorreria, como foi dito, necessariamente através dos saberes objetivos transmitidos pelo professor ao aluno, para que este por fim, consiga superar a alienação e tomar consciência de sua condição social, podendo assim transformar a sociedade (Saviani 1997b, Duarte 2001).

\section{Pensamento educacional pós-modernista no debate sobre currículo}

Dentre os inúmeros debates teóricos e desafios à prática escolar postos por esta discussão uma importante se refere ao que ensinar, quais valores e conteúdos devem fazer 
parte do currículo das escolas. Considerando as mutações epistemológicas, éticas e políticas apontadas no capítulo I, o currículo escolar tem sido objeto de grande reflexão.

Pérez Gómez (2001:22) aponta para uma crise na cultura crítica ${ }^{18}$ influindo de modo substancial no âmbito escolar. A sensação de perplexidade pela qual passam docentes, intelectuais e pesquisadores reflete diretamente no desvanecimento dos fundamentos que legitima, ao menos em tese, a prática pedagógica e escolar. Segundo o autor,

analisar e entender o sentido complexo e plural do pensamento e ideologia pós-modernos são chaves centrais para compreender os influxos culturais que penetram a vida da escola.

A existência de uma crítica profunda aos princípios e valores de determinados estatutos da modernidade produz ressonância na cultura escolar na medida em que juízos de valor e critérios de racionalidades sobre o que é o verdadeiro, o justo, o belo, o útil, etc., estão postos à critica sob outra ordem epistêmica e moral. É nesse sentido que Della Fonte (2004:1 mimeo) constata haver na área de pesquisa educacional contemporânea, a mobilização por esta ordem de indagações:

A prática educativa pode ser guiada por valores de pretensão universal? É legítimo aspirar uma fundamentação racional para a educação? Quais princípios devem nortear a seleção de conteúdos e métodos de ensino? O discurso pedagógico encontra sentido na malha de crenças de uma cultura ou na realidade objetiva? O projeto de formação de um sujeito livre, responsável e autônomo ainda se sustenta como ideal educativo?

Tais questionamentos refletem bem a dicotomia pela qual passa a cultura crítica e, sobretudo, os impactos produzidos para aqueles que trabalham com a educação escolar. Não por acaso têm emergido nos debates e estudos educacionais contemporâneos sobre a escola temáticas tais como os critérios para como deveria se estruturam currículos escolares - a cultura cotidiana/local x a cultura científica/universal, o multiculturalismo, relativismo cultural; as múltiplas dimensões da razão - reflexiva, comunicativa, procedimental - e suas potencialidades; a (re)configuração das relações didáticas professor-conhecimento-aluno; as reflexões sobre as micro-relações culturais na escola, com seus poderes e saberes constitutivos dos modos de produção desta cultura; e as potencialidades e limites da escola educar para a cidadania.

\footnotetext{
${ }^{18}$ Para o autor a cultura crítica é "o conjunto de significados e produções que, nos diferentes âmbitos do saber e do fazer, os grupos humanos foram acumulando ao longo da história. É um saber destilado pelo contraste e o escrutínio público e sistemático, pela crítica e reformulação permanente, que se aloja nas disciplinas cientificas, nas produções artísticas e literárias, na especulação filosófica, na narração histórica...” (p.21).
} 
O pensamento que buscou não apenas situar, mas também explicitar a ordem do discurso cultural ocidental proveniente do Iluminismo, evidenciando assim, as vozes que falam por ele - muitas vezes branca, masculina, dominante e colonialista -, contribuiu para que se pudesse desvelar os mecanismos e formas de poder subjacentes aqueles que falam por outros e seu caráter etnocêntrico.

Tais análises têm contribuído, ao menos, para uma revisão mais crítica do que deve compor os currículos e cultura escolares. Em termos práticos, Pérez Gómez (2001:33) chama a atenção para o fato de que se vê ainda a persistência à tendência etnocêntrica de delimitar os conteúdos e valores dos currículos pela história do pensamento científico - e incluiria ainda, de uma versão européia, masculina, branca e vitoriosa.

Do lado oposto ao etnocentrismo, temos uma posição relativista que, por vezes, recai ou num particularismo exacerbado ou num historicismo radical. Tanto a ordem epistêmica quanto a ordem moral (conhecimento e ação) se reduzem e se tornam reféns de uma verdade e de uma realidade que só poderia existir dentro das convenções sociais compartilhadas por determinada comunidade no tempo-espaço.

Ora, se é importante reconhecer que ao universalizar determinados discursos científicos e/ou morais, que se escoram na falsa idéia de neutralidade e imparcialidade sobre a realidade - pois estão, na verdade, carregados de juízos de valor (em termos de etnia, gênero, classe social, etc.) e de interesses políticos e econômicos -, não se pode perder de vista a necessidade de estabelecer critérios de julgamento do que e como a realidade é cognoscível, assim como de quais valores e práticas culturais devem ser estimuladas e respeitadas nos ambientes escolares. Caso contrário, se cairia no paradoxo do "relativismo absoluto".

Tal problemática projeta à educação e ao currículo escolar um questionamento duplo: há valores e saberes tido como universais a serem difundidos entre todos aqueles que vivem o processo escolar, ou, se não, como se deve organizar e selecionar os currículos escolares sem cair em um "currículo único" (Sacristán, 1999:180)? Cabe então pensar que "relativizar" o conhecimento e a ação moral não podem significar um "vale-tudo" pedagógico e social na escola.

O desafio que se coloca a uma sociedade tida como globalizada e uma escola como instituição de atuação e (re)produção cultural localizada é a capacidade de construir significados e entendimentos de forma compartilhada levando em conta as diferenças e apoiado, sobretudo, em acordos que especifiquem os valores, muito mais que os conteúdos concretos (Pérez Gómez, 2001). 
A grande finalidade em "abrir" o currículo escolar para a diversidade cultural é, não só avalizar o caráter polifônico da sociedade globalizada (em oposição ao pensamento único tão em voga nesta tendência atual da economia mundial de livre mercado), como, sobretudo, ser capaz de aprender com a diferença. Para além do etnocentrismo e do relativismo, o que a sociedade contemporânea, em geral, e as escolas, em particular, se deparam é com a necessidade de "construir marcos universais de convivência humana, respeitosos com as diferenças e comprometidos com a construção compartilhada" (Pérez Gómez, 2001:44). Na mesma linha Moreira (1998:27) afirma que é necessário, seja ao campo teórico-crítico do currículo, seja ao que se implementa nas escolas, a perspectiva que releva o "direito à diferença", implicando na construção de um currículo que se efetive pela representação de vozes até então marginalizadas e oprimidas e na confrontação com as vozes historicamente consolidadas. 


\section{Capítulo III - Projeto político-pedagógico, currículo e cidadania - um estudo de caso de uma escola pública paulistana}

Após este percurso sobre questões de ordem filosófica e sociológica tão amplas e por vezes muito "distantes" da cotidianidade, pode-se trazer à tona, então, o universo de estudo empírico central deste trabalho, que é a dinâmica da vida de uma escola, em seu projeto político-pedagógico e currículo em ação.

É o momento agora de mergulhar na dimensão microssocial da escola, de colocar uma lente de aumento sobre a dinâmica das relações e interações que constituem o cotidiano escolar em suas múltiplas faces, institucionais e organizacionais, pedagógicas e sociais, de forma a compreender o papel e atuação que cada sujeito assume nestas inter-relações e na constituição que dão - neste jogo de forças muitas vezes contraditórias e divergentes - ao seu currículo tanto ao que se refere ao conteúdo de ensino quanto aos valores, tanto ao conhecimento historicamente constituído quanto à ação moral e cidadã.

Nesse sentido, é o momento de "dar voz" aos personagens da escola, deixar a escola direção, coordenação, alunos, professores, agentes escolares e comunidade - falar a respeito de sua própria dinâmica, de seu cotidiano, de suas propostas político-pedagógicas de trabalho, de sua inserção social como instituição, de seu papel educativo. Espera-se que daí emirjam categorias de análise essenciais para se estabelecer um diálogo entre os dados empíricos e o referencial teórico que baliza este trabalho.

\section{Método - justificativa e procedimentos}

Vale portanto comentar a respeito da escolha da metodologia do estudo de caso para este trabalho, apontando suas contribuições e limites. Tomando por base os estudos de Ludke e André (1986), André (1995, 1992) e Oliveira-Formosinho (2002), a pesquisa empírica deste trabalho se fundamenta em uma abordagem qualitativa pois se entende que os critérios de verdade, do trabalho científico, a relevância dos resultados da pesquisa e a questão da objetividade do conhecimento devem passar pela relação pesquisador-pesquisado e pelo modo de inserção/envolvimento e compreensão de um universo pelo outro (André 1992). OliveiraFormosinho (2002) chama a atenção para a dimensão subjetivista e interpretativa desta abordagem, pois se assume que existem múltiplas realidades, e que a "realidade" concebida e escrita pelo pesquisador é fruto de como se estabelece a relação com o campo, a partir dos pressupostos filosóficos, políticos e ideológicos de pesquisador e pesquisados. As 
observações, entrevistas, diálogos, fotos e análises de documentos da escola devem ser entendidos, assim, como elementos que subsidiam a interpretação da realidade proposta pelo pesquisador e que aquilo que no relato-texto se materializa como "real-verdadeiro" é, na verdade, a atribuição de determinados significados propostos pelo pesquisador a partir de sua inserção e interação com o campo.

Mais importante do que buscar estabelecer generalizações dos fenômenos, é a compreensão, através de determinadas ações, práticas e discursos presentes na vida da escola, do currículo a partir dos significados atribuídos por seus agentes. Segundo Ludke e André (1986:37/38) o que se busca é a descrição da situação, compreendê-la, revelando seus múltiplos significados, "deixando que o leitor decida se as interpretações podem ou não ser generalizáveis com base em sua sustentação teórica e sua plausibilidade”.

Ainda sobre as características das investigações qualitativas Oliveira-Formosinho (2002:99) ajuda a sistematizar as variáveis que orientam este tipo de investigação e que de certa forma, estão impostas a este trabalho:

\begin{abstract}
A perspectiva holística, a orientação naturalística, o caráter nãointervencionista, a sensibilidade ao contexto, a importância da perspectiva dos participantes, (...) a coleta direta dos dados, a importância dos dados ricos, descritivos, o investigador como primeiro instrumento, (...) a descoberta da compreensão e do significado, o tempo prolongado de presença do investigador no terreno, o contrato pessoal.
\end{abstract}

Por conseqüência, pode-se dizer que a pesquisa qualitativa se dá de forma aberta, indeterminada, pois, embora haja certos pressupostos, é tão-somente a partir da investigação empírica que as reais perguntas são construídas e elaboradas. Em outras palavras, se as perguntas viessem prontas e fechadas, o campo só serviria para ratificar ou negar as indagações feitas a priori.

A razão do tipo de pesquisa escolhido ser um estudo de caso deve-se ao fato de que me propunha a entender um caso - o currículo de uma escola - em sua unidade e complexidade, dentro de um contexto social específico. Conforme afirmei na Introdução deste trabalho, acreditava que me deparava com uma escola que tinha um diferencial, uma singularidade, ou seja, que ela se distinguia de outras pela forma como exercia algumas de suas atividades, relações sociais, saberes e objetivos, portanto, a construção de seu currículo escolar. Somente um estudo de caso daria, então, uma visão profunda e ao mesmo tempo ampla do que viviam alunos, professores, coordenadores pedagógicos, assistente e auxiliar de direção e diretor, agentes escolares e funcionários administrativos (André 1995). Enfim, numa 
palavra, tal abordagem deveria ser como que uma "fotografia em movimento" ou nos dizeres de Ludke e André (1986:21), investigação de "uma unidade em ação". O risco que corria e que é característico desses estudos corresponde à dificuldade de dimensionar e limitar este caráter aberto e descritivo desta abordagem levando a terrenos teóricos e propositivos superficiais e inconsistentes.

Tendo tudo isto em mente, mesmo que de forma, às vezes desarticulada, às vezes inconsciente, procurei desenvolver a pesquisa de campo recorrendo à variedade de dados, coletando-os em diferentes momentos, em situações variadas e com tipos diferentes de agentes ao que tangia amplamente o currículo da escola. Para tanto, a) foram percorridas situações como a dinâmica da sala de aulas (Ensino Fundamental I e II), os horários de reunião coletiva de professores (as chamadas JEIs ${ }^{19}$ ), reuniões entre direção e coordenação, entradas e saídas de turnos, eventos culturais da comunidade em que escola estava envolvida, atividades culturais e esportivas desenvolvidas pela/na escola; b) foram estabelecidas inúmeras conversas informais e formais através de entrevistas semi-estruturadas com alunos, pais, professores, coordenadoras pedagógicas (CPs), agentes escolares e administrativos, diretor, assistente de direção e auxiliar de período; e c) foram analisadas documentos escritos como o projeto político-pedagógico (PPP) da escola do ano de 2005, um documento produzido pela atual gestão sobre a história da escola e os 10 anos de sua gestão e o plano de ensino de alguns professores do EF II.

Embora não se queira retomar o que foi discorrido na Introdução deste trabalho referente ao fato de que antes de ingressar no programa de Mestrado já havia feito uma pesquisa com a mesma escola, é necessário dizer que, naquele momento, além de observações, e conversas informais, foi feita uma entrevista com as duas coordenadoras pedagógicas juntas, com a professora da sala de informática e com um aluno da $8^{\mathrm{a}}$ série.

Já a partir do ano de 2004, se intensificou minha a ida à escola, o que gerou no $1^{\mathrm{o}}$ semestre uma conversa formal com 6 professores, depois com 10 alunos e com 4 agentes escolares, a respeito, sobretudo, do projeto político-pedagógico, sobre a representação que

\footnotetext{
${ }^{19}$ Com base em Domingues (2004:30) assim se entende a legislação (lei 11.434/93) que explicita a finalidade das possíveis jornadas de trabalho na escola municpal de São Paulo: "1) Jornada básica (JB) com 18 (dezoito) horas-aula semanais em regência de classe e 2 (duas) horas-aula em atividades; 2) Jornada Especial Ampliada (JEA) com 25 (vinte e cinco) horas-aula semanais em regência de classe e 5 (cinco) horas-aula em atividade; 3 ) Jornada Especial Integral (JEI) com 25 (vinte e cinco) horas-aula semanais em regência de classe e 15 (quinze) horas-aula adicionais, sendo que 11 (onze) horas-aula devem ser cumpridas na escola e 4 (quatro) horas-aula em lugar de livre escolha. A lei, nos seus incisos I e II do artigo 41, regula o emprego das horas adicionais, dos optantes pela JEI, que devem ser usadas no desenvolvimento do trabalho coletivo da equipe escolar, inclusive formação contínua, reuniões pedagógicas, preparação de aula, pesquisas, seleção de material pedagógico e correção de avaliações e atividades com a comunidade, com exceção do reforço, recuperação e reposição de aulas".
} 
tinham daquela escola, suas mudanças, suas práticas e seu diferencial. Já no $2^{\circ}$ semestre de 2005, foi intensificado ainda mais minhas idas à escola, tornando possível a realização das seguintes entrevistas semi-estruturadas ${ }^{20}$ :

- Diretor;

- Assistente de direção;

- Auxiliar de período;

- Coordenadoras Pedagógicas (2, realizadas individualmente);

- Professores (3, realizadas individualmente);

- Alunos (realizadas em 2 grupos de 4 , integrantes das $7^{\mathrm{a}}$ e $8^{\mathrm{a}}$ séries);

- Agentes escolares (realizadas em 4, coletivamente) ${ }^{21}$.

\section{A escola - o campo e suas descobertas}

A Escola Municipal de Ensino Fundamental (EMEF) está incrustada no bairro do Parque Peruche, na Zona Norte da cidade de São Paulo. Uma região pobre que, historicamente destinada ao povoamento das populações mais pobres da cidade, predominantemente negra, absorveu aqueles que foram sendo "expulsos" das regiões centrais da cidade por conta da especulação imobiliária, criando assim um movimento migratório que trouxe o samba, para esta região, como grande manifestação cultural ${ }^{22}$. É um bairro que desde a década de 60 foi planejado e loteado para ser uma região residencial. Até hoje em dia vêemse poucos prédios altos e o desenvolvimento mais do comércio de demanda local do que um pólo financeiro-comercial estruturado (Marcelino, 2003).

\footnotetext{
${ }^{20} \mathrm{O}$ roteiro com perguntas das entrevistas segue anexado ao final do trabalho.

${ }^{21}$ Vale uma breve menção sobre a definição de alguns cargos dos profissionais da escola: o Diretor é o responsável administrativamente pela instituição, tendo como função central ordenar o trabalho do setor pedagógico e do administrativo e "prestar contas" (financeira e pedagógica) a Coordenadoria de Ensino. Seguido a ele vêm o Assistente de direção, que funciona como um vice-diretor. Hierarquicamente subordinado apenas à direção tem a função de dirigir a escola na ausência daquele e dar suporte à direção (rumo) da escola. A Coordenação pedagógica, na Rede Municipal paulistana, é composta por dois profissionais, tendo como função essencial orientar, facilitar e intervir no trabalho do corpo docente, de forma a interferir (in) diretamente na ação de sala de aula. Ao mesmo tempo, cabe mediar as demandas do corpo docente com a Direção e Coordenadoria de ensino. O Auxiliar de período tem um trabalho mais direto com o horário de aula, busca fazer com que o período de aulas transcorra "tranqüilamente", orientando alunos e dando suporte aos professores. Os Agentes escolares são os funcionários que se encarregam do trabalho de manutenção, ordenação e limpeza da escola. Vale dizer, que esta divisão e determinação de funções não imiscuem, em tese, o caráter educativo de cada profissional, na medida em que instituição é uma escola e os agentes centrais de sua existência são os alunos.

${ }^{22}$ Não por acaso, a grande maioria das escolas de samba de São Paulo ou estão na região central ou na zona norte da cidade. Marcelino (2003: 77/78) afirma que os recém-chegados habitantes do Pq. Peruche eram na maioria negros e "antes de chegar ao bairro moravam exatamente onde ocorreu o desenvolvimento do samba em São Paulo, ou seja, a Bela Vista.”.
} 
Ao lado da escola, do outro lado do muro, há uma Escola Municipal de Ensino Infantil (EMEI), e no muro oposto, um balneário. Segundo moradores do bairro e agentes da escola, e isto é realmente visível ao se percorrer seu entorno, não há muitas áreas de lazer, cultura e esporte na região, o que fez inclusive esta escola procurar desenvolver estes tipos de atividades para satisfazer a demanda e trazer a comunidade para dentro dela.

\subsection{Da trajetória histórica da escola - rupturas e mudanças}

Inicialmente, até por delimitação histórica de análise, gostaria de resgatar um pouco da trajetória da escola nos últimos anos a partir de um documento elaborado pela gestão ${ }^{23}$ que assumiu a direção em finais de 1995 (e que até então se mantém), adicionado aos depoimentos que vieram de conversas, bate-papos e entrevistas com os diferentes integrantes - diretor, auxiliar e assistente de direção, CPs, professores, alunos e agentes escolares.

O documento, ao recuperar a origem histórica da escola, desde sua fundação até sua última gestão, aponta para uma mudança contundente na visão que a comunidade escolar e seu entorno tinha da instituição. Até por volta de 1995/6 a escola era chamada de "maloquinha", e com a nova equipe gestora se compondo a partir deste período, as ações e representações da escola também foram se alterando:

Criada em 30/08/1956 como Escola Mista do Imirim, em 1958 foi denominada II Escolas Agrupadas do Imirim. A partir de 01/04/69 passou a ser Escola Municipal Comandante Garcia D' Ávila.

$\mathrm{Na}$ década de 50, a escola funcionou numa área rural. A região foi inicialmente ocupada por religiosos. A área do bairro foi loteamento da fazenda da família Peruche.

O apelido 'maloquinha' vem de um processo de abandono do velho prédio da escola, que ficava localizado em outro local distante $800 \mathrm{~m}$ do atual prédio. $\mathrm{O}$ abandono da construção (de madeira) chegou ao abandono total. A idéia era não investir, pois um novo prédio estava em construção (...) No período de 1985/87 ocorreu um processo de muita violência no entorno, ocorrendo mortes no interior da escola. A escola tinha uma disciplina rígida e autoritária.

O projeto interdisciplinar foi desenvolvido de 1989 até 1992. A partir de ciências/matemática no projeto gênese, que posteriormente agregou mais professores. De 1993 a 1995, cada um se virou na escola como podia.

\footnotetext{
${ }^{23} \mathrm{O}$ documento fornecido pelo diretor, não tem paginação é tem mais o teor de um relato memorístico da trajetória da escola.
} 
Em um trecho seguinte do documento, o diretor relata o "quadro" em que encontrou a escola quando assumiu o cargo de direção.

Quando ingressei na unidade (outubro/95) encontrei:

- Uma divisão de grupos;

- Operacionais que brigavam muito;

- O prédio estava mal conservado. Paredes, salas, tudo feio, pichado;

- A coordenação pedagógica trabalhava dividida (N I e N II).

- As coordenadoras resolviam quase "tudo" (paternalistas);

- Alunos agressivos;

- A escola era desrespeitada e invadida;

- Alguns professores muito comprometidos e trabalhando muito;

- Não havia um processo de construção coletiva;

- O grupo sempre buscava uma voz de comando, uma ordem;

- Quase nenhum recurso pedagógico

Num segundo momento, relata o que foi possível ser feito de acordo com as condições humanas e materiais pela qual a escola passava. Questionava, assim, por onde começar a mudar as relações sociais e pedagógicas.

O primeiro momento foi de observação e descoberta das relações e significações do grupo. A grande pergunta que ouvia era 'o que você quer de nós?' Era necessário agregar as pessoas, apontar para um projeto. A situação era difícil, a maioria estava desanimada. Um grupo tinha visão autoritária. Havia um pequeno grupo que tinha discurso e comportava prática. O maior problema foi com o grupo que tinha discurso e não sustentava nenhuma ação.

Para romper com esta condição de abandono e de fragmentação da ação educativa na escola, o diretor conta que apostou na construção do que chama de "gestão colegiada". Ele, chegando a finais de 95, o assistente de direção, que viera inicialmente como candidato de oposição, respaldado por parte do corpo docente contrário às mudanças que despontavam, em 96, e as duas CPs em 97, buscaram montar uma equipe de trabalho que apontava para uma gestão coletiva como formação dos profissionais da escola. $\mathrm{O}$ assistente de direção referenda estas mudanças ao avaliar o "salto qualitativo" que a escola deu nestes últimos 10 anos:

A gente fechou com a equipe de direção, lá há 10 anos atrás, com as duas CPs, que eram novas. Está escola cresceu, hoje ela tem 1015 alunos, nos 3 turnos. Quando eu cheguei tinha 4 turnos e tinha 600 e poucos alunos, estava fechando, porque era mal vista.

Por conta disso, alguns elementos históricos, estruturais e situacionais da escola, entre 96 e 98, levam a crer que naquele momento germinava um processo de mudança radical da 
escola. Primeiro, pela postura reconhecida do diretor por muitos funcionários, de enfrentamento do status quo social e pedagógico em que ela se encontrava. Segundo ele, muitos professores não queriam mudanças e tentavam de várias formas, desarticular e descreditar as propostas que surgiam. Momento crucial da história da escola foi a reforma do prédio pela qual passou ao longo de 97 quando, ao invés de suspender a maioria das aulas, pois as salas estavam obstruídas, resistiu à reivindicação de parte dos professores e manteve o calendário normalmente.

Em entrevista ele recupera este momento:

Em 97 a escola sofreu uma reforma, que foi definitiva para os seus rumos...foi a pedagogia do caos, construtivo. Tivemos todas as aulas o ano inteiro com reforma e tudo. Os professores se revoltaram, dizendo que não era assim que funcionava... resumindo, teve professor dando aula debaixo da bananeira, aula no estacionamento, no pátio, o ano inteiro. Quem não queria nada foi embora no ano seguinte, deu uma limpada, a escola começou a ficar com uma outra cara, e o caos mexeu muito com as pessoas, com a auto-descoberta, dos espaços, das relações, de ser solidário nesse momento de conflito, e aparece a questão de equipe, de grupo, e a partir daí o grupo começou a crescer, desenvolver, a ter uma unidade.

Outro ponto de ruptura foi logo de início se preocupar em estabelecer uma aproximação maior com a comunidade. Este mesmo documento afirma:

Sozinho e contra a vontade de todos, iniciei um processo de abrir a escola aos finais de semana. Mensalmente foi realizado um baile no ano de 1996. A partir de 1998 foi intensificado o processo de ocupação da escola pela comunidade.

Ao longo desses 10 anos, a escola estabeleceu inúmeras parcerias, com ONGs, fundações, empresas, associações, escolas de samba e organismos do bairro, com atividades de alfabetização, esportivas, culturais, etc. Desde 1998, a escola abre aos fins de semana com uma série de atividades - karatê, capoeira, judô, aulas de cavaquinho, teatro -, cede o pátio interno para os eventos festivos da comunidade como festas de aniversário, casamento, etc. como forma de angariar novos fundos para fazer pequenas reformas.

Um terceiro pilar da mudança foi o investimento na formação dos profissionais da escola. A direção diz:

Fomos buscando formação. Não ficamos esperando a Prefeitura. Buscamos parceiros, companheiros e voluntários... fizemos uma formação aqui pesada, desde o materialismo dialético-histórico, à concepção de Estado, governo, sociedade... tudo isso que todo mundo deveria saber... o que é Piaget, Vigotski... 
A escola buscou, além de fazer uso do aparato estatal de formação, trazer pessoas de diversos setores da sociedade para vir discutir temas com o corpo docente e de funcionários. Entretanto, segundo a direção, o investimento na formação dos profissionais da escola, não se limitou a palestras sobre novos saberes para a prática educativa. Foi necessário intervir na cultura das micro-relações sociais do setor administrativo à relação entre professores e agentes escolares:

Educar os funcionários da secretaria de que eles estão numa escola pública, que têm que educar, portanto, que eles não são só burocratas, são educadores e que o burocrático tem que estar a serviço da educação é preciso um trabalho difícil de formação. Hoje eles já atendem melhor o público e os professores.

Quando conversei com um grupo de agentes escolares, foram categóricas em dizer que antes do início desta gestão, havia uma divisão muito clara, direção e professores de um lado e agentes escolares do outro. Afirma a agente escolar A:

Antigamente era professores de um lado, funcionários, de outro, não tinha este entrosamento. Isso mudou com a entrada do diretor que disse que são todos iguais, todos educadores. Não tem esta separação...podemos sentar na mesma mesa. Antes a gente era discriminada...com a outra direção era difícil, era preciso muito esforço, pra gente conseguir falar com eles.

Hoje a fala do diretor reflete a mudança do olhar: "às vezes eu tenho um agente (escolar) que lava banheiro que é mais educador que muito professor".

Ao discorrer sobre esses processos e acontecimentos recuperados pela memória/ registro de direção, coordenação, professores e agentes escolares, foi-se percebendo que as mudanças pela qual passou a escola foram resultado de múltiplas ações e práticas sociais e discursivas capazes de atingir seus diferentes agentes - não só seus profissionais, mas sobretudo aqueles que demandam pelo ensino: os alunos. Isto no mínimo pela fala de muitos quando comparar sua escola com outras, outras que inclusive muitos irão quando terminar o Ensino Fundamental. Assim a aluna A reflete e compara sua escola com as demais: "nenhuma tem a qualidade dessa. Os professores são muito bons, eles sabem dar aula, sabem conversar, dialogar. Ela é bem organizada. Nas outras eles estão xingando os professores...os alunos rabiscando, ninguém faz nada".

Foi necessário oferecer um ambiente físico limpo e preservado, investir nas relações sociais internas, fortalecendo os laços afetivos e coletivos de seus profissionais. Além disso, abrir, no seu duplo sentido, a escola para a comunidade, de forma a fazer compreender que tanto a comunidade deveria (ou poderia) ocupar a escola, como esta deveria vincular seu 
trabalho pedagógico às manifestações culturais da comunidade - histórias do bairro e seus personagens, parceria com as escolas de samba da região, organização de eventos em parcerias com as outras escolas do entorno, (como 2 festas de comemoração dos 69 e 70 anos do bairro Pq. Peruche) - para que houvesse um ambiente propício para a relação ensinoaprendizagem $^{24}$.

Tem-se aqui uma primeira pista do que se pode aprofundar no decorrer da análise dos dados empíricos, ou seja, o vínculo entre as ações sociais e pedagógicas do currículo da escola com as mutações sociais contemporâneas e a ordem do pensamento pós-moderno. A fragilização da atuação e intervenção do Estado, a reconfiguração política do sujeito contemporâneo, o advento de novos movimentos sociais, a idéia do que deveria constituir o próprio currículo da escola puseram esta escola a buscar internamente, entre seus agentes e sua estrutura, formas de responder a estes problemas, desafios e dificuldades. A escola, para além da estrutura da Rede de ensino municipal, recorreu ao investimento na gestão escolar e na abertura e aproximação com a comunidade do entorno como forma de encontrar margem de ação política, na medida em que demandava por mudanças, seja nas práticas de ensino, seja em seu papel social.

\subsection{Da estrutura escolar}

Além da reforma estrutural pela qual passou, outros elementos se agregam ao espaço físico. A escola comporta 14 salas de aula, uma sala de vídeo, uma de Artes, uma de Leitura, uma de Informática, uma de Ciências, uma para reuniões de professores (para as JEIs). Ao sair deste prédio se depara com um pequeno pátio semicoberto que dá acesso ao um outro espaço coberto, onde os alunos lancham, com a cozinha de um lado e um palco do outro. É neste espaço também que acontecem as atividades esportivas e as festas e casamentos da comunidade aos fins de semana. Atravessando este espaço, chega a uma outra área aberta com pequenos jardins e com a visão à esquerda para as quadras esportivas. São duas quadras, sendo uma coberta em estado razoável (não mais que isso) de conservação.

\footnotetext{
${ }^{24}$ Embora também não se queira com isto predizer nem tampouco buscar assegurar de que nesta escola se "aprende mais e melhor".
} 


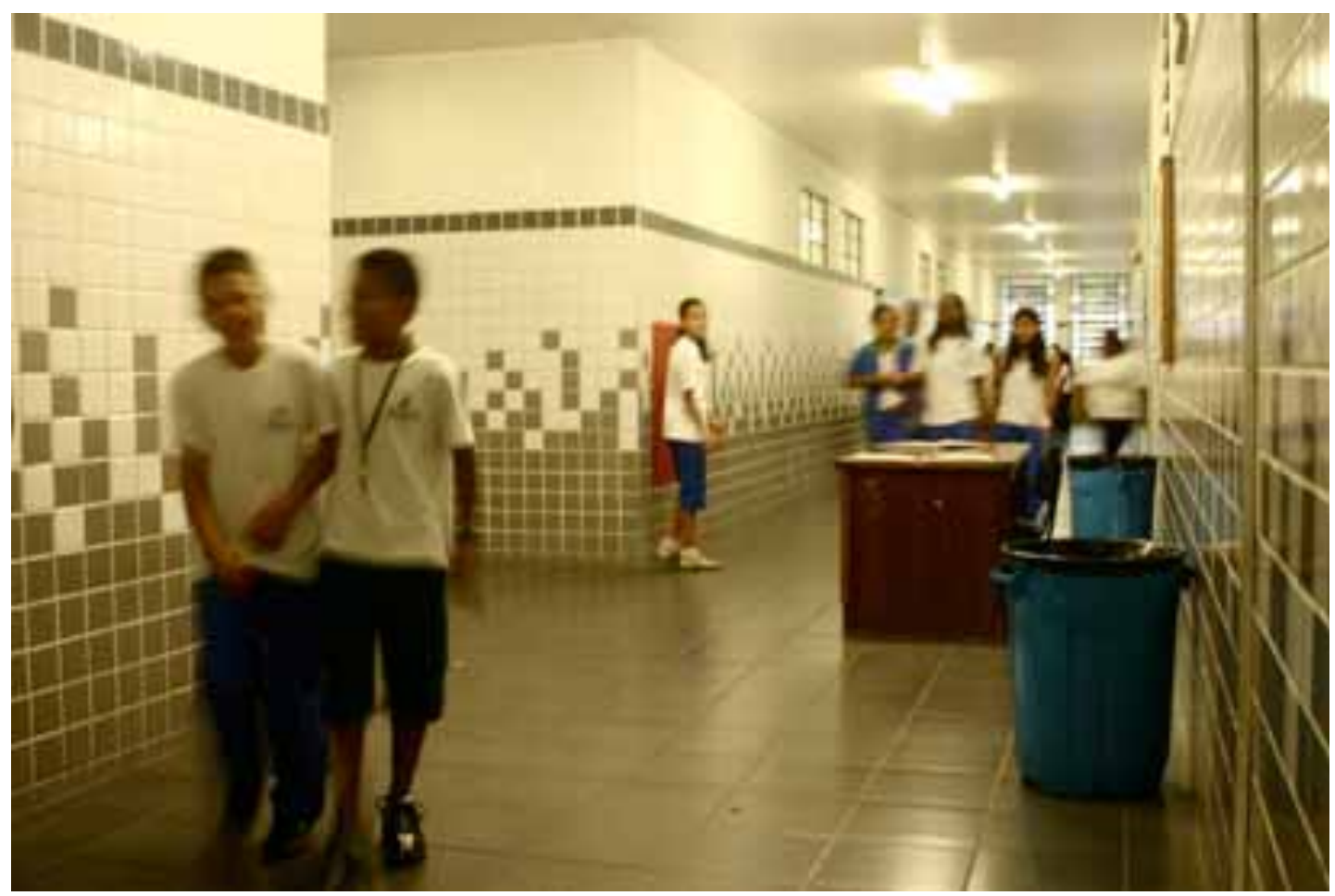

Nos corredores da escola, alunos se preparam para descer para o intervalo de aulas

Em fase final está a construção de vestiários ao lado das quadras, resultado de uma parceria entre a escola e a Encontro Nacional dos Estudantes de Medicina, na qual a escola alojou centenas de estudantes para um encontro nacional por uma semana. No último dia do Encontro do ano de 2003 o então Ministro da Saúde visitou a escola.

$\mathrm{Na}$ antiga área destinada a um estacionamento para os funcionários (há ainda uma outra área de estacionamento) foi construída uma horta, uma área verde de lazer e um espaço para churrasqueira agregada a uma pequena e nova cozinha. Os eventos festivos, de confraternização dos funcionários são feitos neste espaço.

As salas de aulas estão razoavelmente bem conservadas, com um armário, ventiladores e cortinas. As carteiras, velhas e sujas. As estruturas de metal das mesas e cadeiras estão pintadas com líquido corretivo. Por quase todos os vidros há grades que os protegem, para quase todas as fechaduras há uma porta que deve estar trancada. Praticamente todos os funcionários andam com um molho enorme de chaves e, ao entrar e sair das salas de aula, os professores têm que mantê-las trancadas. Os mecanismos de segurança e proteção ao patrimônio público estão introjetados na escola, assim como de qualquer outra. 


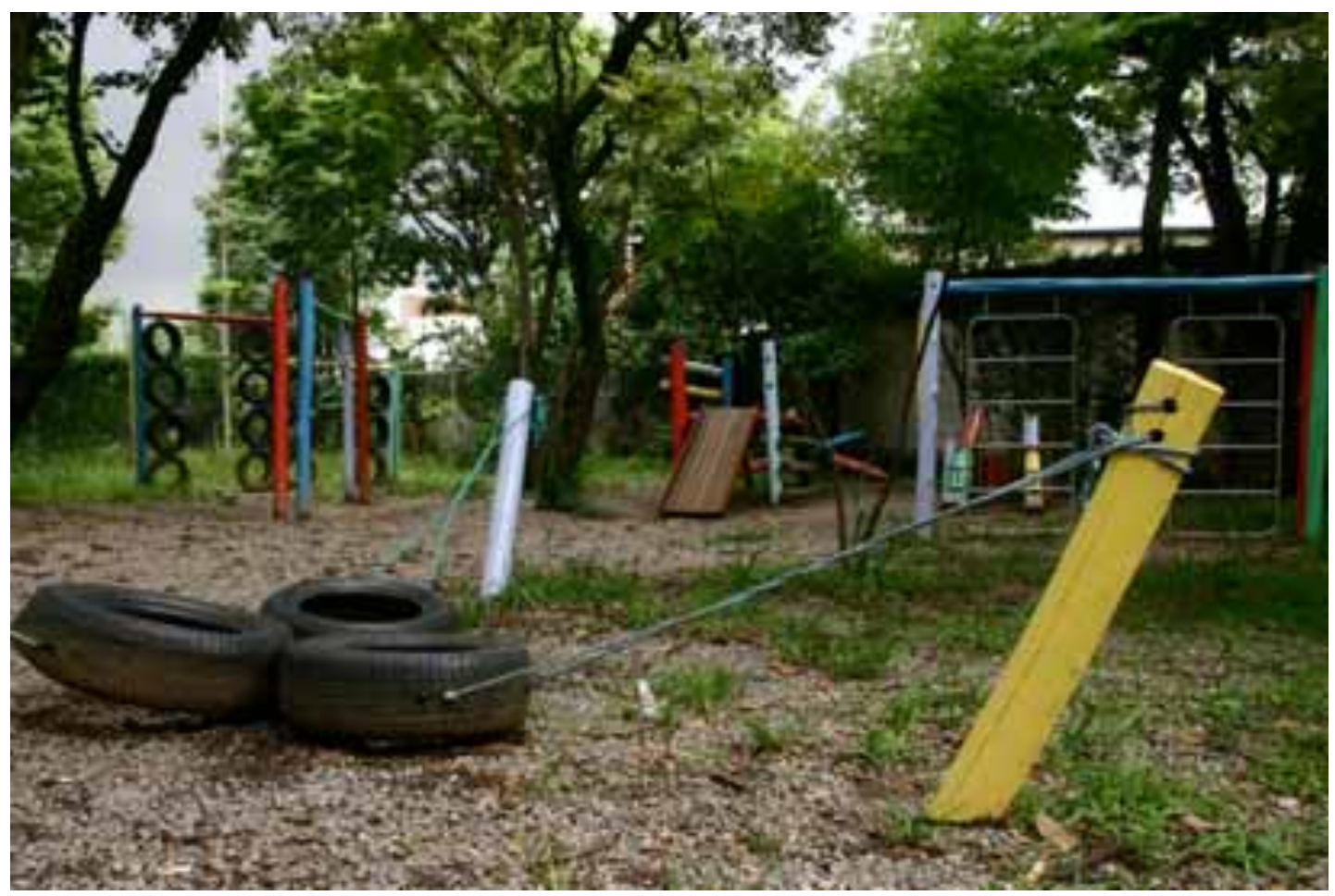

Antiga área de estacionamento de carros dos funcionários da escola, o espaço foi transformado em parquinho com horta e churrasqueira para eventos da escola

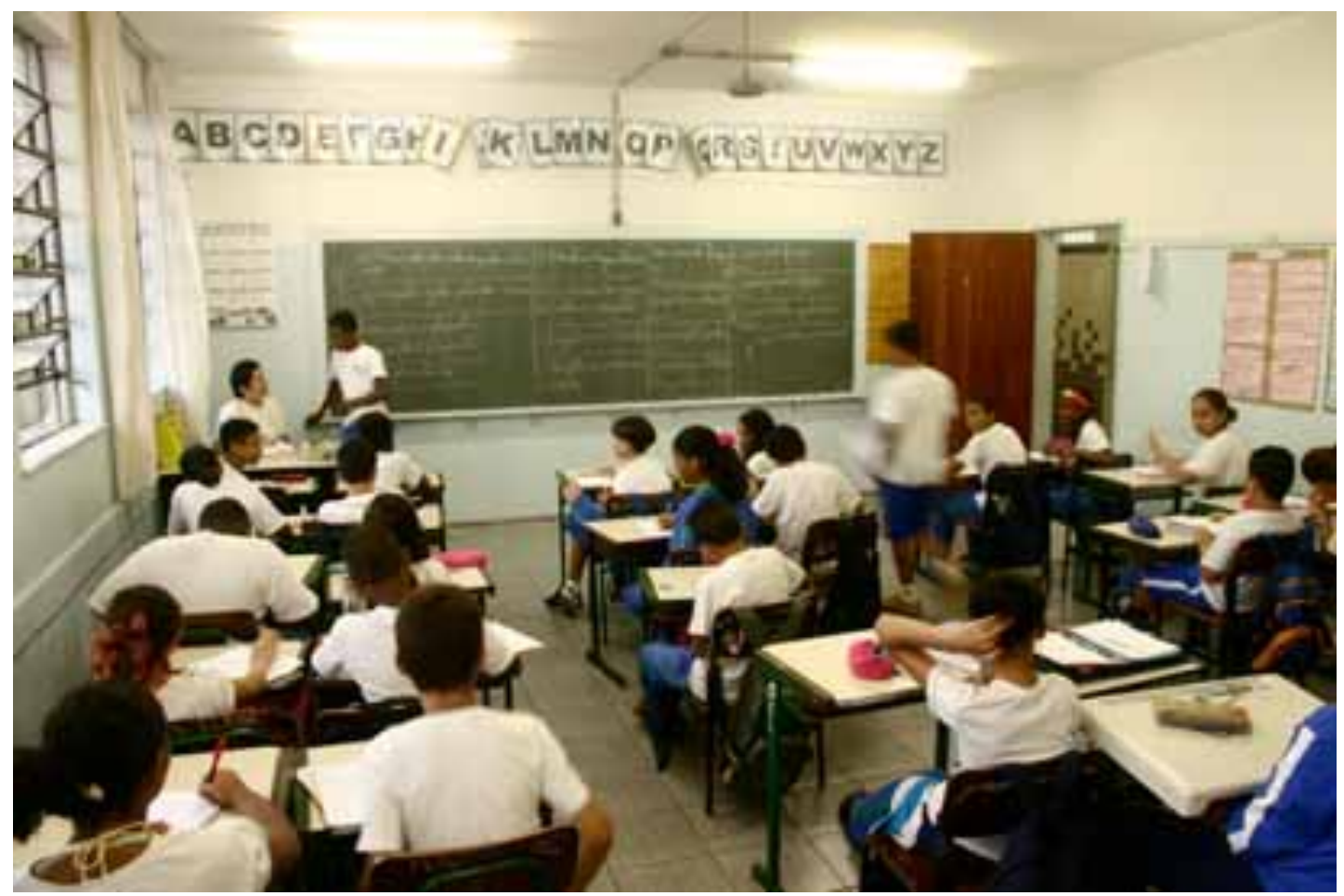

Aula de Português em uma $5^{\text {a }}$ série (primeiro ano do Fundamental II)

Os banheiros, salas, chãos e paredes estão praticamente limpos, não se vê muita sujeira pelos cantos, nem escritos nas paredes. Ao longo do ano, foi possível observar a ocupação das paredes dos corredores para apresentar os trabalhos que cada classe ia fazendo. Costumam 
colocar ao lado da porta, cartazes, desenhos, gravuras, avisos, que iam sendo confeccionados ao decorrer do ano letivo.

Se for verdade que as idéias mudam a partir das determinações materiais da realidade, a partir de 1997, a escola começou a "mudar de cara" com tal reforma estrutural do prédio e com sua nova "política de preservação". É praticamente consenso e reconhecido entre alunos e professores, corpo diretivo e funcionários, que a escola deu um salto qualitativo no nível de conservação em suas dependências internas. Praticamente não há nenhum canto da escola com aparência de abandono, com pichações nas paredes, depredações ou (muitos) vidros quebrados. Todos reconhecem não só os esforços feitos, mas sobretudo, que atualmente é muito mais difícil haver alguma ocorrência que afete o patrimônio escolar. Em praticamente todas as entrevistas, com alunos ou professores, novos ou antigos, agentes escolares ou direção, quando perguntei sobre o que diferenciava aquela escola das demais, a condição de preservação da escola aparecia como elemento consensual.

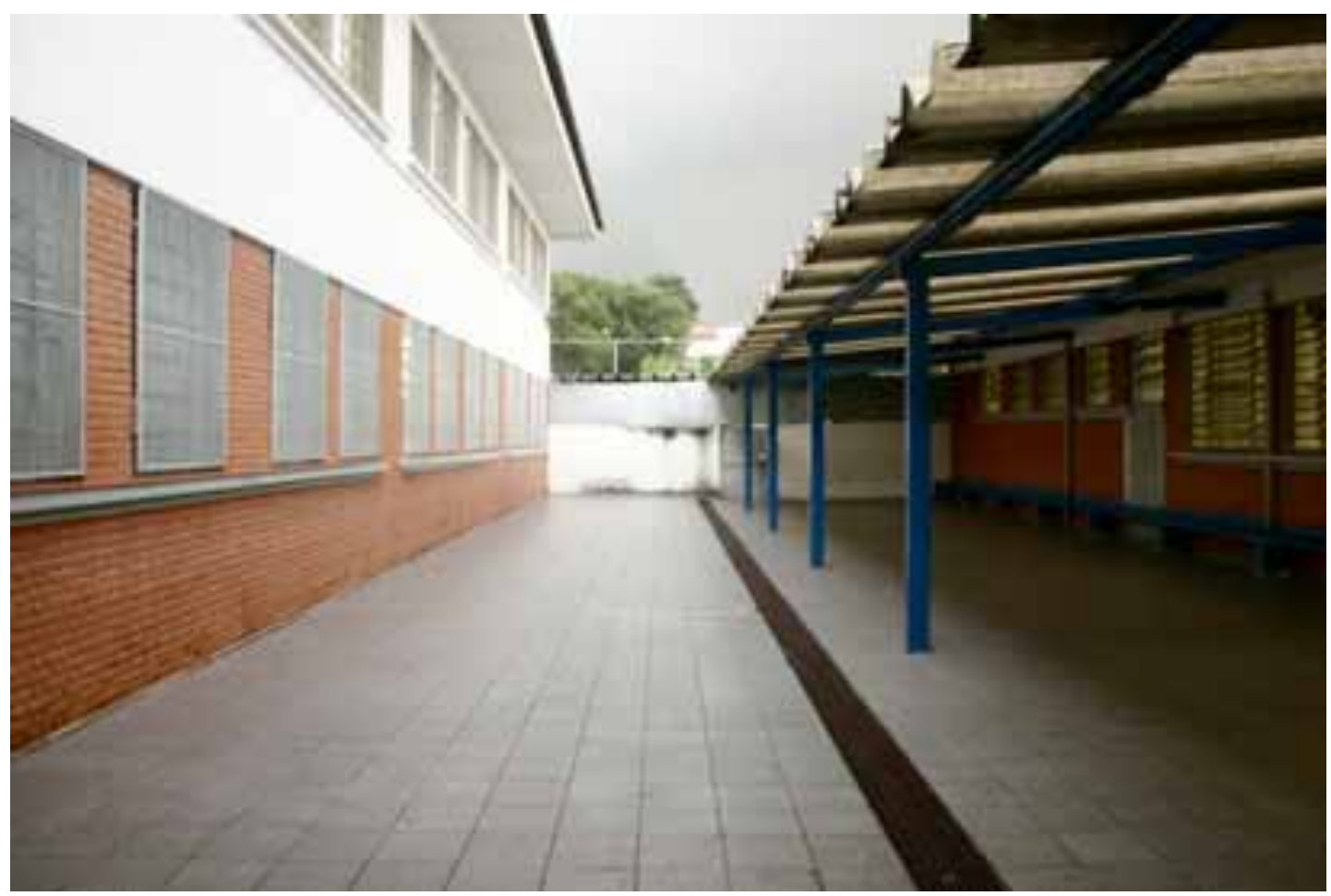

Espaço que divide o prédio das salas (à esquerda) do pátio coberto (à direita)

Ao refletir sobre as estratégias de ação para manter a escola conservada, me fez recordar quando numa conversa, o diretor contou que anos atrás, quando esta luta contra as pichações/depredações era mais intensa (pois algumas pessoas estavam pichando as salas de aulas constantemente) percebeu que a única saída para a superação deste problema, era ser mais eficiente e rápido que os pichadores e pintar as paredes tão logo elas fossem pichadas. 
Disse, então, que após uma pichação feita numa sexta-feira, ele e o assistente de direção foram no sábado repintar a parede para que na segunda-feira não só não tivesse "rastros da obra" como, e principalmente, demarcasse a mensagem de que as pichações não vingariam mais na escola.

O assistente de direção, que é tido como o "faz-tudo" da escola afirma:

Eu lembro quando nós pintávamos as salas, conforme entrava dinheiro, e a gente tinha que repintar todo final do ano. Depois de um tempo não precisava mais repintar a escola toda. Chegava e repintava só umas paredes e tinha sala que não tinha nada pra fazer... Antes, tinha que consertar todas as portas. Estavam despedaçadas. Todo ano tinha que trocar todas as fechaduras 3 vezes por ano. Agora não, é só manutenção.

Enfim, sem dúvida, a qualidade do ambiente físico impressiona pela sua preservação, sobretudo se for comparado à maioria das escolas municipais da cidade. Embora isto não permita inferir alterações diretas na prática pedagógica de sala de aula, pode-se ao menos, levar em consideração que um espaço preservado, respeitoso (em termos de manutenção, limpeza e organização) tende, de fato, a favorecer a continuidade da preservação e respeito por aqueles que chegam e utilizam este espaço.

\subsection{Do projeto político-pedagógico}

Tratar do projeto político-pedagógico (PPP) de uma escola supõe de antemão, considerar que o pesquisador está adentrando um universo cultural-educativo dinâmico, em movimento. Sabia assim, que me depararia com um PPP, não só elaborado teoricamente, mas de fato, em (permanente) construção; que entrecruzaria, portanto, um tempo-espaço específico daquela escola. Tempo este de "sedimentação dinâmica" de certas idéias e ações, discursos e práticas, em movimento, que estavam sendo renovadas, repensadas e reconstruídas. Espaço este de luta por certos discursos e não outros, por certas práticas e não outras e que, nas relações entre os diversos agentes se evidenciavam os conflitos, as divergências e convergências da comunidade escolar.

Nesse sentido, estava motivado a, além de verificar quais condições reais as escolas públicas têm tido para implementar e desenvolver seu projeto pedagógico, como fizeram alguns estudos ${ }^{25}$ (o que me remeteria para a análise das políticas públicas educacionais), a

\footnotetext{
${ }^{25}$ Cf. Dissertações de Mestrado de CARRER, Andrea. C. A construção do projeto político-pedagógico do CEFAM Butantã, São Paulo: FEUSP, 1999 e SILVA, Vandré. G da. Projeto pedagógico na escola pública: elementos para sua compreensão, São Paulo: FEUSP, 2001.
} 
compreender como uma escola opera seu projeto a partir das condições concretas dadas, o que ela faz ou deixa de fazer, segundo os pressupostos assumidos coletivamente, implícita ou explicitamente.

Na medida em que buscava entender como se desenvolvia o PPP, sabia que o caráter de autonomia no e do trabalho pedagógico-escolar, já apontado pela própria LDB 9.394/96, seria elemento central de baliza do trabalho pedagógico daquela escola. Gadotti (2000:34) ao afirmar que "nunca o discurso da autonomia, cidadania e participação no espaço escolar ganhou tanta força", obriga a pensar o PPP, em termos teóricos, exigente de uma gestão democrática e participativa da escola. Quais vozes eram ouvidas? Quem era incluído? Quais falas eram ditas, quais relações sociais e afetivas eram almejadas? Quais intencionalidades aquele universo escolar buscava efetivar, para além da estrutura administrativa, burocrática e pedagógica que a rede de ensino paulistana impunha a toda e qualquer escola de sua rede?

Assim, estaria de acordo com autores que apontavam para o caráter político do projeto pedagógico (Gadotti 1994, Veiga 2001a, Sousa 2001a), afinal se entende que não há prática pedagógica ausente de intencionalidades nem de escolhas dos sujeitos. Severino (1998) chama de "intencionalidade significadora" o caráter político do projeto pedagógico, o que vai ao encontro de Veiga (2001b:13) quando afirma ter o projeto um caráter, ao mesmo tempo

político, no sentido de compromisso com a formação do cidadão para um tipo de sociedade (...), e pedagógico, no sentido de definir as ações educativas e as características necessárias às escolas de cumprirem seus propósitos e sua intencionalidade.

Quando entrevistei a coordenadora pedagógica B e também o assistente de direção, encontrei uma fala que dizia que o PPP não era da coordenação ou da direção, mas sim de todos que compunham a escola, prescindindo, portanto da participação ativa e de coresponsabilidades de seus integrantes. Afirmavam assim que era o conjunto de princípios e valores, pressupostos e ações norteadoras das relações e do trabalho pedagógico.

Mas como era feita esta articulação? Como se dava a ação dos sujeitos envolvidos na construção do PPP, quais os instrumentos, técnicas e métodos que o projeto disponibilizava, estimulava para o seu desenvolvimento? Quem era incluído? E como participavam? Sob quais eixos?

Isto remeteu a investigação empírica à fase em que a escola inicia, por volta de 1998/9, suas ações pedagógicas em torno do eixo-tema intitulado, Eu e o Mundo. O assistente de direção afirma que dessa forma poderiam conceber um PPP que fosse amplo e capaz de articular as múltiplas dimensões da relação do sujeito com o mundo - a subjetividade, a 
relação com o próximo, com a estrutura social mais ampla, etc. Segundo ele, foi curioso perceber a amplitude que a proposta atingiu, pois

as pessoas perceberam que o PPP não era só para os alunos. Aqui muitas pessoas tiveram que fazer uma auto-análise. O professor trabalhando com o aluno fez uma auto-análise e cresceu! A partir do momento que ele aceita que estava num caminho errado, que estava devendo, aí ele passa a crescer. O legal é quando você vê os professores se integrarem, se juntam, mas sem a pressão da direção, sem acordo prévio. Um começa a ver o que o outro está fazendo e se integra.

Dentro deste tema, Eu е о Mundo, o PPP foi se alterando ano a ano, explorando, por vezes, as relações com o meio ambiente, por outras, com o próprio ser humano e no ano de 2005, em que estive mais intensamente na escola, o tema central era o mundo do conhecimento e o conhecimento do mundo. Parecia central explorar a relação professor-aluno com o conhecimento desenvolvido na escola. Este processo se mostra claro nas palavras do diretor:

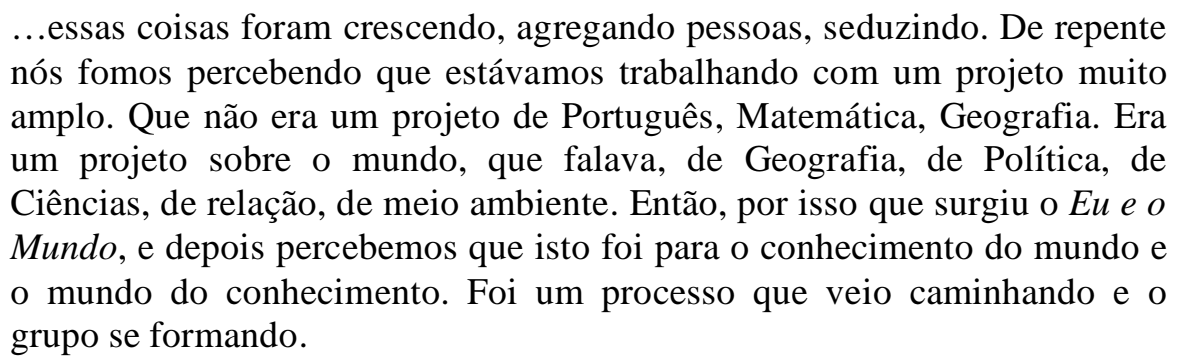

Ao ter acesso ao documento do PPP escrito pela escola, foi possível captar alguns indicativos importantes a respeito das "intencionalidades" político-pedagógicas da instituição. O documento, que se divide em tópicos referentes à definição do PPP, seus objetivos, metas, ações e sugestões para 2005, pode ser, de forma geral, assim explicitado.

No que se refere à definição, afirma o documento que é um "instrumento teóricometodológico que busca a mudança" e que isto só pode ser alcançado através de uma "proposta coletiva e participativa", "com uma proposta conjunta da escola, uma linha comum de atuação". Em seguida, explicita como características básicas a abrangência, como "ampla e global”, a funcionalidade, como "“guarda-chuva' de outros projetos”, a duração, como longa (vários anos), a participação, como "coletiva e democrática", a concretização como "processual" e a avaliação, como "permanente e vinculada a articulação ação/reflexão/ação". De alguma forma subjaz aí a proposição de Severino (1992:85/86), quando afirma que o PPP é um conjunto articulado de propostas e planos de ação em função de finalidades baseadas em valores previamente explicitados e assumidos, e que, portanto, só poderá ser entendido no 
aspecto da participação coletiva, uma vez que a fragmentação das práticas escolares em ações individuais, isoladas e desarticuladas contribui para a própria perda do significado da idéia de projeto.

Em seguida, nos objetivos, ressalta-se o caráter de continuidade do trabalho/conquistas atingidas. Trata-se desde a manutenção da escola como espaço cultural e a "continuidade do processo de construção de uma escola agradável, democrática, inclusiva e produtiva" até o auxílio na "formação de cidadãos alfabetizados, críticos, éticos, independentes, criativos e ativos" e a "estimulação da auto-descoberta e valorização do aluno". Em tais objetivos vê-se um "toque Ilustrado", através da preocupação com a formação "integral" dos alunos e sua autonomia, assim como o próprio caráter de escola democrática-cidadã. Nota-se, entretanto, que embora se trate da formação dos indivíduos, a ação docente não aparece como eixo para a mudança mencionada acima, remetendo apenas a escola como um todo.

Dentre as metas estão a preocupação com a organização e autonomia dos sujeitos (em geral) e da própria escola, a manutenção do ambiente físico, a coerência e a coesão da equipe escolar, "a difusão do hábito de leitura, escrita e produção oral" e a "ampliação das competências no processo de ensino e aprendizagem”. Aqui se têm desde menções de caráter mais vago e geral, como "autonomia" e "organização", até metas mais específicas que atingem, por fim, o trabalho docente, como a preocupação com as habilidades de leitura e escrita.

Ao que se refere às ações, o documento apresenta alguns mecanismos gerais de obtenção de tais metas e objetivos, tais como, acordar a participação de "todos" nos projetos desenvolvidos na escola; estimular à criação de "projetos específicos ${ }^{26},(\ldots)$ estabelecendo relação com a realidade do aluno, partindo do que ele conhece, ampliando-a"; "desenvolver os conteúdos atitudinais, procedimentais e conceituais com os alunos e estabelecer metas de resultado ano/ciclo". O que se nota é que na medida em que o documento do PPP vai se "afunilando", se especificando, vai cada vez mais atingindo e intervindo especialmente no trabalho docente, muito mais do que dos outros integrantes da escola, seja coordenação/direção seja dos próprios alunos.

Por fim, nas sugestões para 2005, estão afiguradas "campanha de solidariedade e paz", "não responder a violência com violência", "promover o diálogo" e "valorizar as pessoas", “interessar-se pela comunidade", "fazer parcerias e juntar forças", "cuidar das causas dos problemas", "conhecer e usar os recursos legais" e "não se silenciar diante das

\footnotetext{
${ }^{26}$ Especifica o documento os seguintes temas: orientação sexual, drogas, meio ambiente, filosofia e inclusão.
} 
injustiças". O que muitas vezes, mais se apresentam como proposições vagas de ação individual e/ou coletiva do que propriamente estratégias e ações pedagógicas, seja do corpo docente, seja da escola como um todo. Para muitas propostas, a dificuldade de discordar de seu teor moral e político é da mesma grandeza da possibilidade de sua realização.

Um outro documento que vale a pena ser trazido para a análise, mesmo que não exaustivamente, é um chamado "contrato escola-aluno". Curiosamente, embora fosse chamado por este nome, parece mais um "manual de instruções" para os professores a respeito do que devem fazer com seus alunos, para um bom "funcionamento" da escola. Seguem alguns de seus itens principais: explicitar os objetivos, conteúdos, regras, etc., no início do ano letivo; orientar sobre o cuidado com o material didático; corrigir os exercícios dando uma devolutiva sobre o desempenho; ensinar os alunos a pesquisar, resumir, utilizar agenda e dicionário; ajudar na saída de período; solicitar que os alunos recolham o lixo da sala; trancar as salas depois de sair. Estão aqui inúmeras e diversas proposições e ações sobretudo para os professores. O que revela certo paradoxo, pois seu caráter "prescritivo" vai de encontro a certos pressupostos "acordados" anteriormente no próprio PPP, como a autonomia do trabalho docente. Entretanto, este "contrato escola-aluno" parece querer mais sistematizar e agrupar certos acordos antes explicitados do que propriamente determinar como deve ser o trabalho do professor. Talvez, na verdade, sua real função seja esta duplicidade: ratificar o conhecido e controlar pela sutileza.

É evidente que não se pode e não se deve compreender estes 2 documentos como "instrumentos totais" capazes de circunscrever e delimitar "oficialmente" as práticas, ações e discursos da escola. Seguramente qualquer que seja o documento, não se crê abarcar as múltiplas demandas, criações e realizações que sustentam a vida e a cultura de uma escola. No entanto, mesmo assim, eles "dão pistas" e indicativos de por onde a escola, coletiva ou fragmentariamente, consensual ou dissensualmente aponta suas diretrizes e proposições de trabalho.

Nesse sentido, o conteúdo dos 2 documentos aponta para um caráter mais voltado para a dimensão das relações sociais e afetivas, da participação coletiva e das regras e valores a serem compartilhados do que propriamente aos conteúdos e procedimentos didáticos a serem atingidos na relação ensino-aprendizagem de sala de aula. Este direcionamento "textual" dos documentos já indica onde (e como) se concentra a atuação educativa, pedagógica da escola, conforme se pretende mostrar adiante.

Mas "por onde" se pode enxergar as diretrizes e ações do PPP? Como ele se executa através do currículo da escola? O que e quem o faz mover suas engrenagens? Quais são seus 
principais "aditivos", seus conteúdos centrais que o faz sustentar e dar sentido a vida e ao trabalho de tantos sujeitos?

É evidente que não se pode buscar respostas fechadas e objetivas para tais (e outras) perguntas. Mesmo assim, é possível, apontar algumas categorias que ajudam a melhor compreender os caminhos constitutivos do currículo em ação desta escola.

\subsection{Da gestão escolar}

Um primeiro ponto, além de ter chamado muito a atenção na investigação empírica, que se pode considerar, em si, como o motor ativo do PPP e da execução do currículo escolar é a gestão escolar, sua composição pedagógica, suas articulações políticas e suas objetivações curriculares. Como já fora apontado acima, a gestão da escola se preocupou essencialmente com a criação de um ambiente físico favorável à aprendizagem e à efetivação de relações humanas sadias e produtivas. Nesse sentido, tanto um aluno que encontra em seu espaço escolar o caráter de preservação, limpeza, organização, oferta de infra-estrutura, boa biblioteca, etc. tende a reconhecer e ser exigido daquele espaço relações, no mínimo, mais respeitosas, quanto um professor que ao obter diretrizes e condições de trabalho mais estruturadas, organizadas e claras, também tende a ter um melhor (e quiçá maior) envolvimento com a instituição e seu trabalho.

Entretanto o que foi preciso ser feito para formar uma boa equipe gestora? Que setores da escola são vitais para a efetivação de uma gestão escolar coerente com os princípios e metas do PPP? Quais as principais estratégias tomadas por esta escola? Quem (e o que) orientava a ação político-pedagógica da escola?

Um primeiro princípio e ação que o chamado "núcleo central" - diretor, assistente de direção e as duas CPs - considerou necessário investir foi na mudança das próprias relações humanas internas da escola. Baseado nisso, o assistente de direção aponta o círculo vicioso que muitas escolas caem e que esta procurou interditar:

A Prefeitura vem e injeta dinheiro numa escola, reforma o prédio, etc. Dois anos depois a escola tem que ser reformada novamente. Por quê? Se você não trabalhar as relações...só trabalhar o material não tem como.

O que foi feito? Como romper com este processo degradativo? Romper com ele significa sua total superação? Uma estratégia central foi sem dúvida o tempo de vida deste "núcleo central": o diretor está há 10 anos. Uma das CPs está há 9, a outra e o assistente de 
direção estão há 8 anos. Isto referenda a idéia de que para haver mudanças efetivas na vida e na cultura escolar, o cruzamento de tempo e coesão é imprescindível.

Outro ponto que parece importante é o que se chamaria de "gestão das relações humanas" dentro da escola. Quando foram entrevistados os diferentes agentes foi muito recorrente uma fala que evidenciava uma preocupação em escutar o outro. Alunos e agentes escolares reconhecem que têm facilidade em conversar com direção e coordenação quando têm necessidade. Por outro lado, a direção afirma fazer uso de uma escuta psicanalítica "de perceber o outro, o não falado, o não mencionado, mas percebido. Buscar sempre na relação do grupo, valorizar o humano, cativar as pessoas". A agente escolar B afirma: "as auxiliares (de direção) ouvem a gente. Elas querem primeiro saber o que aconteceu. Primeiro há a conversa...não tem esse negócio de chamar a atenção".

A relação que estes profissionais têm com os problemas e conflitos cotidianos parece estar submetida, na maior parte das vezes, aquilo que o próprio diretor afirmou ser a função pública da escola: "atender a comunidade". E por aqui se pode encontrar um terreno fértil para identificar seu foco de ação político-pedagógico, portanto seu investimento em criar, estabelecer redes de solidariedade entre os diferentes integrantes tendo como foco central o caráter comunitário das relações e como pano de fundo a constituição do próprio espaço público.

O investimento na questão da autonomia do trabalho também parece importante. Fica claro com as observações e entrevistas, que houve grandes avanços tanto para aqueles que vivem o cotidiano quanto para os vêem de fora. A própria agente escolar B afirma: "É muito bom trabalhar aqui. Eu me realizei. A gente trabalha com liberdade, ninguém fica no pé". Quando entrevistei a supervisora pedagógica da escola ela reiterou inúmeras vezes que o maior diferencial desta escola era o investimento nas relações democráticas entre os funcionários.

Eles avançaram muito nesta questão democrática. Por exemplo, os agentes escolares. No começo, elas queriam que o diretor mandasse elas fazerem o serviço, que ele dividisse as tarefas. E ele não mandava. Até que elas foram entendendo e construindo esta autonomia. Você pode ver que é uma escola totalmente limpa, mas quem organiza o trabalho são as próprias funcionárias... Mas ainda precisa muito. Não há tanto entre os docentes com os alunos. Na parte da gestão, equipe técnica avançou muito.

O aspecto autônomo e democrático do trabalho escolar foi visto também em dois momentos interessantes. O primeiro foi quando, no início do ano letivo, na primeira reunião pedagógica da escola, estavam reunidos, professores, agentes escolares, equipe 
administrativa, CPs e direção. A pauta do encontro era, além de informes mais gerais, discutir as diretrizes do PPP. Quando tratavam de quando e como seria a Feira Cultural, muitos participavam manifestando os prós e os contras das propostas, votavam as mais pertinentes e se acatava a vontade da maioria. O interessante era notar que não havia algo pré-definido pela direção e mais, que o que ali era definido deveria ser cumprido. Foi abordado pelas CPs ainda o "contrato didático"(que é aquele contrato escola-aluno mencionado acima) entre professores e alunos. Chamou-se a atenção para que os professores buscassem estabelecer relações com seus alunos de forma a "ouví-los"27; ressaltando-se ainda a importância de estimular o trabalho de pesquisa em sala de aula.

Interessante também foi quando após acabar de chegar à escola, uma das CPs me chamou para observar uma "assembléia" dos estudantes que iria discutir como seria o evento Caça Talentos da escola. Estavam sentados em roda, no palco do pátio, (uns 35 alunos), junto com o corpo diretivo, debatendo se o evento daquele ano seria aberto à participação da comunidade externa ou se só poderia se inscrever alunos da escola para as apresentações artísticas. Mais curioso do que o que se decidia, era o como. Muitos participavam, era preciso levantar a mão, se colocar e assumir uma posição e depois votar, deliberar. Ao pé do ouvido o diretor veio me dizer: "independente do que eles decidam, o importante é que eles aprendam a se organizar politicamente e exercitem a atitude democrática".

A preocupação com a educação para a cidadania e o caráter democrático e autônomo das ações se mostrou, de fato, central para a escola. Talvez não por acaso autonomia, organização e respeito sejam as 3 atitudes definidas no início do ano como aquelas que todo funcionário deve estimular no trabalho com os alunos. Entretanto, reside nela também sua própria contradição. Houve um caso curioso desvelado por uma professora. Quando estive com uns 15 professores do EF II a espera, por mais 25 minutos, da coordenadora pedagógica para iniciar mais uma reunião de JEI, esta professora (d), que estava ao meu lado, me cutucou e perguntou: "você já viu um exército perder uma guerra simplesmente porque seu comandante não apareceu na batalha?" Meio sem resposta, sem saber onde ela queria chegar, ela mesma completou: "pois é o que está acontecendo aqui, agora. Um monte de professores que já sabem o que fazer ${ }^{28}$, e que ficam esperando a CP chegar pra começar o trabalho". Sem perder tempo, emendei: "e depois os professores querem exigir autonomia dos alunos..." ela

\footnotetext{
${ }^{27}$ Já estava combinado que cada professor deveria abrir uma aula mensalmente para conversar com os alunos sobre temas que eles mesmos levantassem. Não soube se ocorreu nem como ocorreu ao longo do ano, pois não observamos a abertura deste momento.

${ }^{28}$ Pois três professores iriam contar como foi um congresso sobre Educação e Mídia do qual participaram.
} 
riu, concordou e finalizou dizendo que muitas vezes os professores, inclusive ela, exigiam dos alunos aquilo que eles não queriam cumprir para com a coordenação.

Numa outra ponta, o assistente de direção se orgulha em dizer que quando há uma excursão ou passeio da escola muitas vezes sequer vai algum professor! "Quem faz a excursão é a inspetora. Ela recolhe o dinheiro faz tudo e vai a agente escolar. Eu não preciso de um professor. A agente escolar vai sozinha com 40 alunos e mais ninguém". Vale chamar a atenção para o quanto a prática e a representação do professor não correm o risco de serem negativamente alteradas, na medida em que a presença do professor parece não ser útil quando se faz uma excursão, um passeio. Entendo que considerar desnecessário a ida do professor para tais atividades é, no mínimo, equiparar o papel e função docente à do agente escolar.

No caso dos alunos, o mesmo assistente de direção conta que estava havendo um campeonato de futebol promovido pelas $8^{\text {a }}$ séries e que eles, supervisionados por um professor, organizaram os times, escolheram os nomes, fizeram a tabela, organizaram o regulamento e compraram as medalhas.

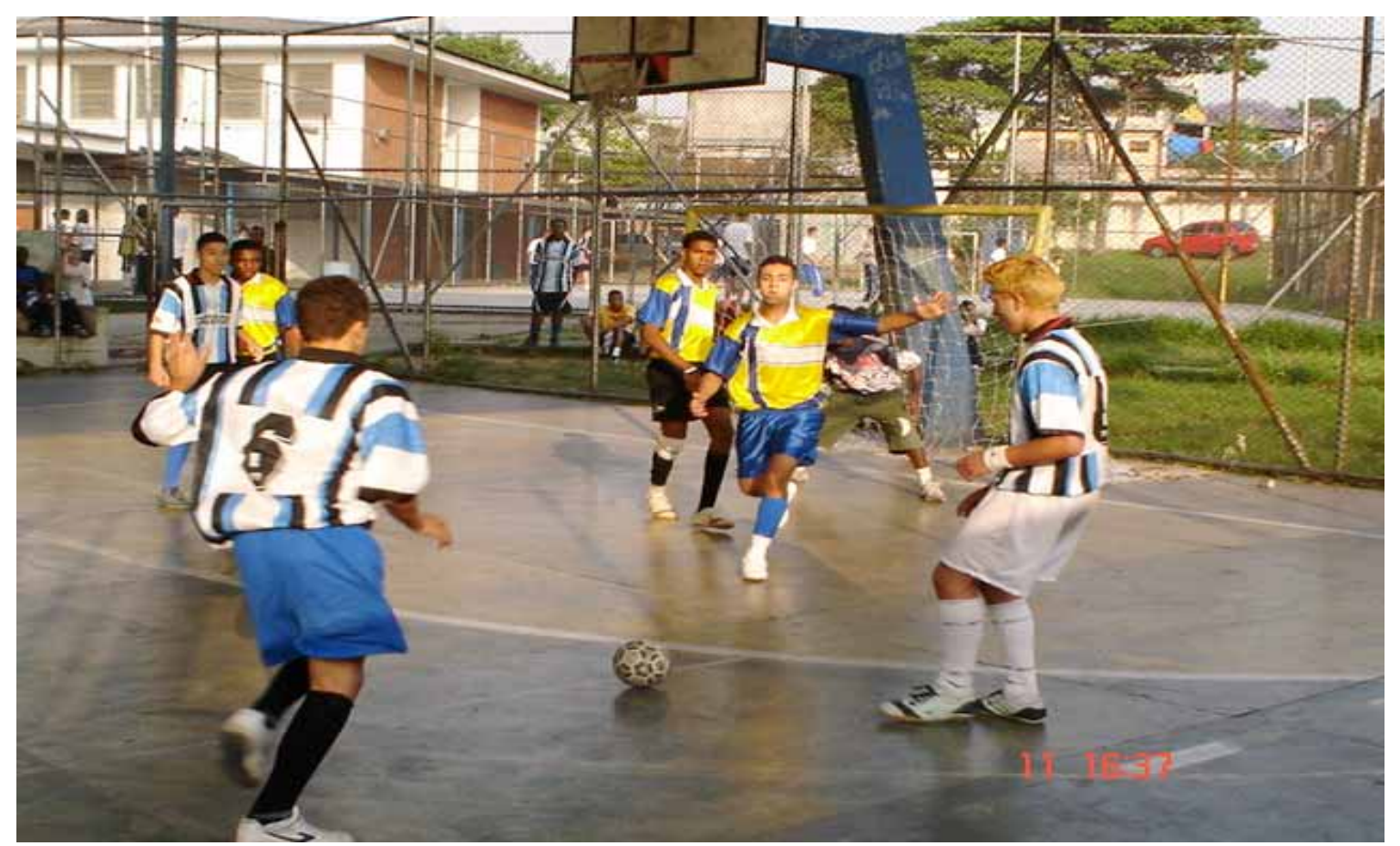

Torneio de futsal com alunos da escola realizado aos fins de semana

Estes relatos levam a crer que, salvo alguns exageros, há nas relações entre os diferentes agentes do espaço escolar um investimento em relações mais autônomas e democráticas do que o de costume, seja em outras escolas, seja nos mais diversos ambientes 
profissionais. Entretanto, isto não assegura nem a intenção nem a realização de uma ação interna autônoma de todos, além de correr o risco de traduzir autonomia por ausência de responsabilidade e/ou responsáveis nas atividades. Ou seja, incorre-se o risco também de os professores se "sentirem liberados" da função formadora por haver "bons agentes escolares" na escola.

Muito do trabalho da escola se traduz na organização, sintonia, tratos e acordos que o "núcleo central" estabelece. O diretor explica como trabalham:

A gente discute em igualdade, em conversa, procura encaminhar das melhores maneiras... Procuramos resolver em grupo, lutando, fazendo concessões, uma gestão colegiada, mas quando há o impasse eu tomo a decisão, tenho que assumir a autoridade. Porque um dos maiores problemas da educação hoje é que falta autoridade na figura do diretor. Em nome da democracia, do democratismo, todo mundo conversa, discute e ninguém toma nenhuma atitude para não ser autoritário. Então aqui nós não temos este problema. Se tiver que tomar uma atitude, eu digo que estou tomando a atitude. Então a gente vai de Piaget a Pinochet, passando por Paulo Freire.

Um outro elemento que parece ligar o trabalho desta equipe e que é sentida por agentes escolares, professores e alunos: a coerência entre os pares gestores e entre o que se diz e o que se faz. O diretor relata orgulhoso e irônico:

A gente percebeu que era uma equipe quando uma professora veio e disse: 'Eu falo com você uma coisa e você fala A, eu falo a mesma coisa com o Assistente de direção e ele também fala A. Poxa todo mundo fala a mesma coisa?' Obrigado, nos somos uma equipe! A gente aprendeu a resolver as coisas aqui dentro e lá fora falar uma coisa só.

Embora a investigação empírica tenha evidenciado que o trabalho político-pedagógico se constitui de forma articulada, colegiada, dialogada entre direção e coordenação, a postura político-ideológica, a ação voltada fortemente para a comunidade (escolar e do bairro), como será visto, revela um investimento e envolvimento pessoal muito forte por parte do diretor da escola. Isto se evidenciou através de observações cotidianas, de relatos de professores, coordenação e agentes escolares, assim como quando conversava com ele na frente da escola sobre os "problemas da educação brasileira" e ele aproveitava para parar os moradores do bairro, alunos da escola, lideranças, etc. para convidar para o almoço que seria promovido no fim de semana.

A supervisora de ensino foi categórica, ao dizer que "a escola tem a cara do gestor diretor". De professores mais antigos da casa até os mais novos percebe-se e reconhece o investimento nesta articulação escola-comunidade, como é o caso da fala da professora B 
Quando vejo na fala do diretor, sempre vejo uma preocupação com a comunidade. Por exemplo, a questão da uniforme, se for mudar, ele diz: se puder mudá-lo, é legal que a gente traga para a confecção do bairro. $\mathrm{O}$ bairro tá precisando de emprego...É como se a escola e o bairro fossem uma coisa só...mas eu vejo que isto é muito do diretor.

As agentes escolares também trazem uma análise interessante a respeito das mudanças de gestão ao longo da história da escola. Quando indagadas a respeito de como era trabalhar naquela escola, a agente escolar A foi pontual:

Aqui tem antes, durante e depois. Você precisa escolher uma delas. Foram diferentes gestões, várias direções. Eu passei várias etapas. Quando entrei (22 anos atrás) era lei nazista, preto com preto, branco com branco. Não havia mistura. Não tinha união. Entrei em 82 e por volta de 90 deu uma melhorada nas relações...na ultima gestão, com entrada deste último diretor, aí que teve a união entre os agentes, professores e direção. $\mathrm{O}$ operacional é quem faz tudo, mas não tinha valor. O diretor fala que somos todos educadores. Essa união veio com ele...

Entretanto vale questionar o que seria desta escola sem este diretor. Seria ela próxima do que se tornou? Haveria tamanha proximidade com a comunidade? E as relações atingiriam este caráter democrático, ou, pelo menos, mais eqüitativo? E o currículo, como será discutido mais adiante, teria um cunho mais construtivista e voltado para a cidadania do que para os conteúdos? Para a escola atingir esta "cara", teria a direção lançado mão de estratégias e mecanismos políticos que determinassem (o que iria de encontro ao caráter democrático da gestão) a seus pares a execução de sua "visão política", pondo assim em prática seus ideais?

Estas são respostas de difícil assertividade, sobretudo, porque exigiria o acompanhamento histórico deste processo e destas mudanças. Mesmo assim, tais relatos e observações indicam a demarcação forte da postura do diretor nas finalidades do que entendem pelo papel social da escola.

Enfim, independente dos caminhos percorridos para se chegar nesta situação - o momento dinâmico no qual me inseri - a escola vive o paradoxo de ver seus melhores funcionários deixar a escola por almejar novos cargos em outras escolas. Assim diz o assistente de direção:

Nós somos uma escola exportadora de professores - para a sala de leitura, para a informática, ou para a coordenação e supervisão. Eles saem daqui e conseguem trabalhar em outros cargos. 
Com relação aos alunos que terminam o Ensino Fundamental II ocorre que muitos se tornam lideranças estudantis, presidentes de Grêmios, havendo casos, como o que vimos neste ano letivo, de estudantes que voltam (ou não conseguem “sair”!) para a escola para trabalhar voluntariamente.

A importância de analisar a questão da gestão escolar, e, sobretudo a gestão desta escola, corresponde ao fato de compreender, como muitos relatos sugerem, que neste movimento de aproximação escola-comunidade, a instituição de relações mais democráticas e eqüitativas, a melhoria nas relações afetivas entre os profissionais da escola, a abertura da escola aos fins de semana tanto para atividades culturais e esportivas, quanto para a realização de eventos e confraternizações da própria comunidade escolar e do bairro apontam na direção de execução de um currículo escolar preocupado com a questão da cidadania e que portanto afeta a percepção, compreensão daquele que move toda esta engrenagem social: o aluno.

\subsection{Da relação escola, família e comunidade}

Ao que se refere à relação escola-comunidade, entendida esta última como as famílias dos alunos, as outras escolas da região, ONGs, Escolas de Sambas e lideranças locais, o processo de aproximação, integração e envolvimento foi se intensificando com o passar destes últimos 10 anos, ou seja, o período de vida desta última gestão.

A estratégia de trazer pais e familiares, novas lideranças comunitárias e organizações sociais para dentro da escola, afetaram não só o dia-a-dia das famílias do entorno, mas também a própria representação que esta comunidade tinha da escola. Se antes, ela era vista como lugar degradado, repudiado, com o processo de "abertura de seus portões", o oferecimento de atividades culturais e esportivas aos fins de semana e a aproximação com as lideranças do bairro e de famílias, faz dela hoje, ser considerada pela supervisora de ensino, como "de referência" na região. Praticamente em todas as entrevistas e conversas - de alunos à supervisora de ensino, de agentes escolares a professores, de direção à coordenação quando perguntado sobre a relação com a comunidade, havia por detrás das falas um reconhecimento, um orgulho e satisfação em ver que a "escola era aberta à comunidade", que a "comunidade usava e ajudava a preservar aquele espaço".

Quando fui resgatar o porquê desta abertura, tocou-se diretamente no desafio imposto pela comunidade, principalmente pelos alunos da época, ao diretor. Assim ele lembra: 
Comecei a conversar com os meninos, a falar sobre ética, ambiente, felicidade, mudanças... Aí tomei uma apunhalada dos meninos porque eles disseram: "você vai tentar mudar, não vai agüentar e vai embora, e como é que a gente vai ficar?'. Isso foi uma paulada. Me senti provocado e não teve como ir embora daqui. Eu não poderia ser mais uma pessoa que passasse por aqui e fosse embora.

Por conta disso, e aliado ao fato de que "essa escola era um caos, um lixo, era chamada de "maloquinha", o diretor reitera que "a relação com a comunidade tinha que nascer...ou partia pra comunidade ou não tinha o que fazer".

A direção conta que no início, o processo de abrir a escola aos fins de semana sofreu enorme resistência de pais e professores. A maioria ou não via sentido ou considerava um risco em termos de violência e danos para a unidade escolar. Ao invés de buscar apoio nos professores, conta que foi necessário se aproximar primeiramente dos alunos e das jovens lideranças. Começaram, então, a fazer bailes mensais para arrecadar dinheiro para a APM (Associação de pais e mestres), o que com o tempo foi diminuindo a resistência dos outros segmentos.

Com o passar dos anos, a mudança na aparência e representação social da escola, a estruturação do trabalho pedagógico, a constante abertura da escola para eventos e atividades, permitiram a aproximação da comunidade e consequentemente o surgimento de novas lideranças comunitárias frutificando na organização de um cronograma de atividades esportivas e culturais para preencher os finais de semana da escola. Um dos maiores investimentos desta relação escola-comunidade foi atentar para o que a comunidade "sabia fazer”. Em muitos casos, são os próprios familiares de alunos os professores de futebol, cavaquinho, teatro ou judô. Tem crescido também o uso da escola para festas de aniversário, casamentos, encontros de estudantes, almoços, formaturas de outras escolas, etc. A agente escolar D sintetiza:

O Garcia se tornou o lugar pra fazer estas festas... A agenda pra casamento está cheia até Janeiro. E quando termina a festa, está tudo no lugar, porta, janela, vaso.

Atualmente diversas atividades extra-classes são oferecidas sistematicamente aos finais de semana: judô, karatê, capoeira, futebol, basquete, vôlei, cavaquinho, teatro, etc. Aos domingos uma comunidade de mais de 100 bolivianos utiliza uma das quadras para jogar futebol. Em troca, a agente escolar C confirma que "eles usufruem e se comprometeram com a direção de ajudar a preservar as quadras, se precisar pra pintá-las ou algo assim...” 
Uma vez combinei com a direção de visitar a escola num sábado. Lá mostraram os projetos em ação. Meninos jogavam futebol na quadra, enquanto no pátio interno aula de karatê de um lado, e do outro, ao fundo no palco, mães preparavam a decoração de uma festa de aniversário de criança. Além das atividades programadas, é freqüente ver afixada nas paredes da escola a oferta de atividades temporárias: aulas de dança, artesanato, etc.

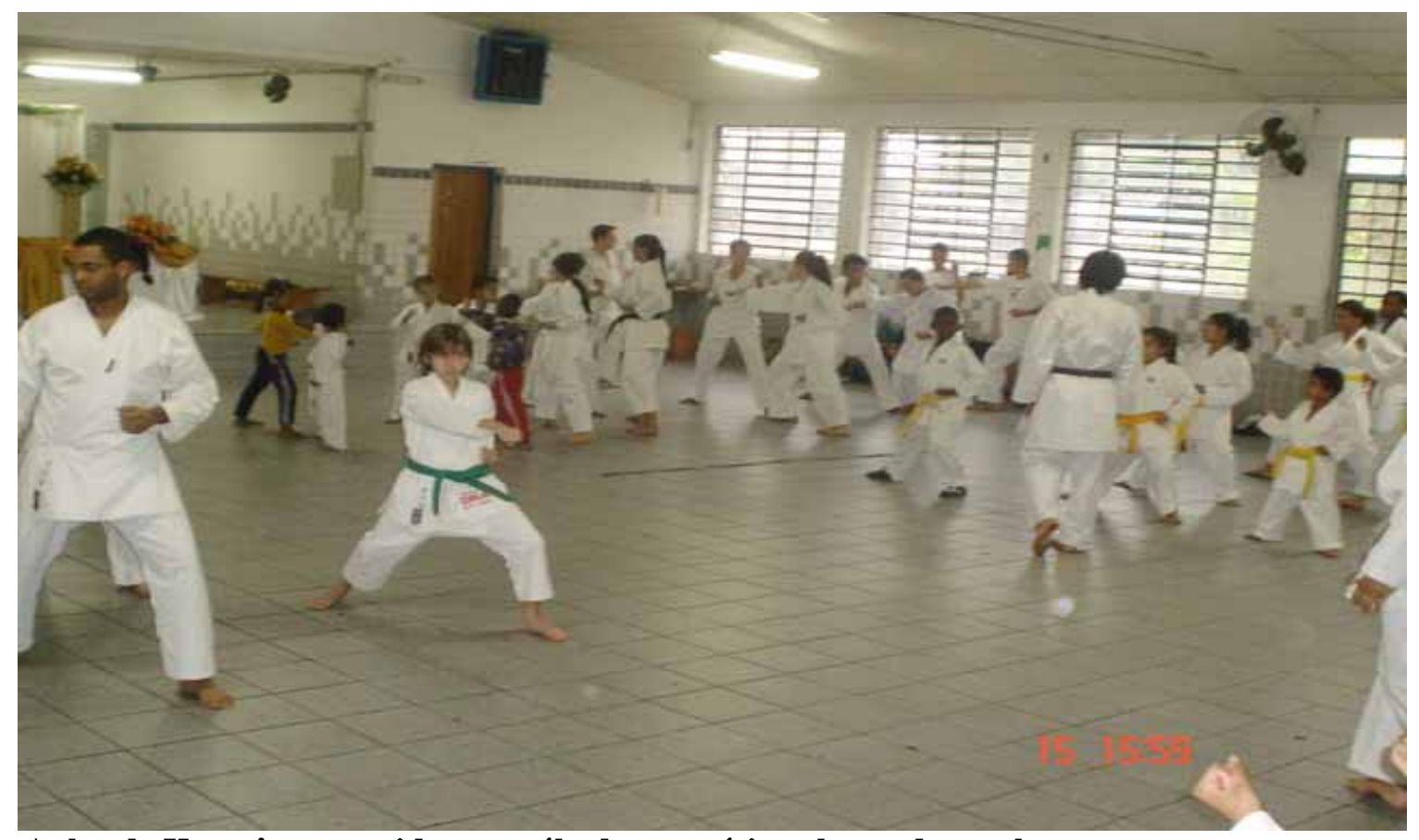

Aulas de Karatê promovidas aos sábados no pátio coberto da escola

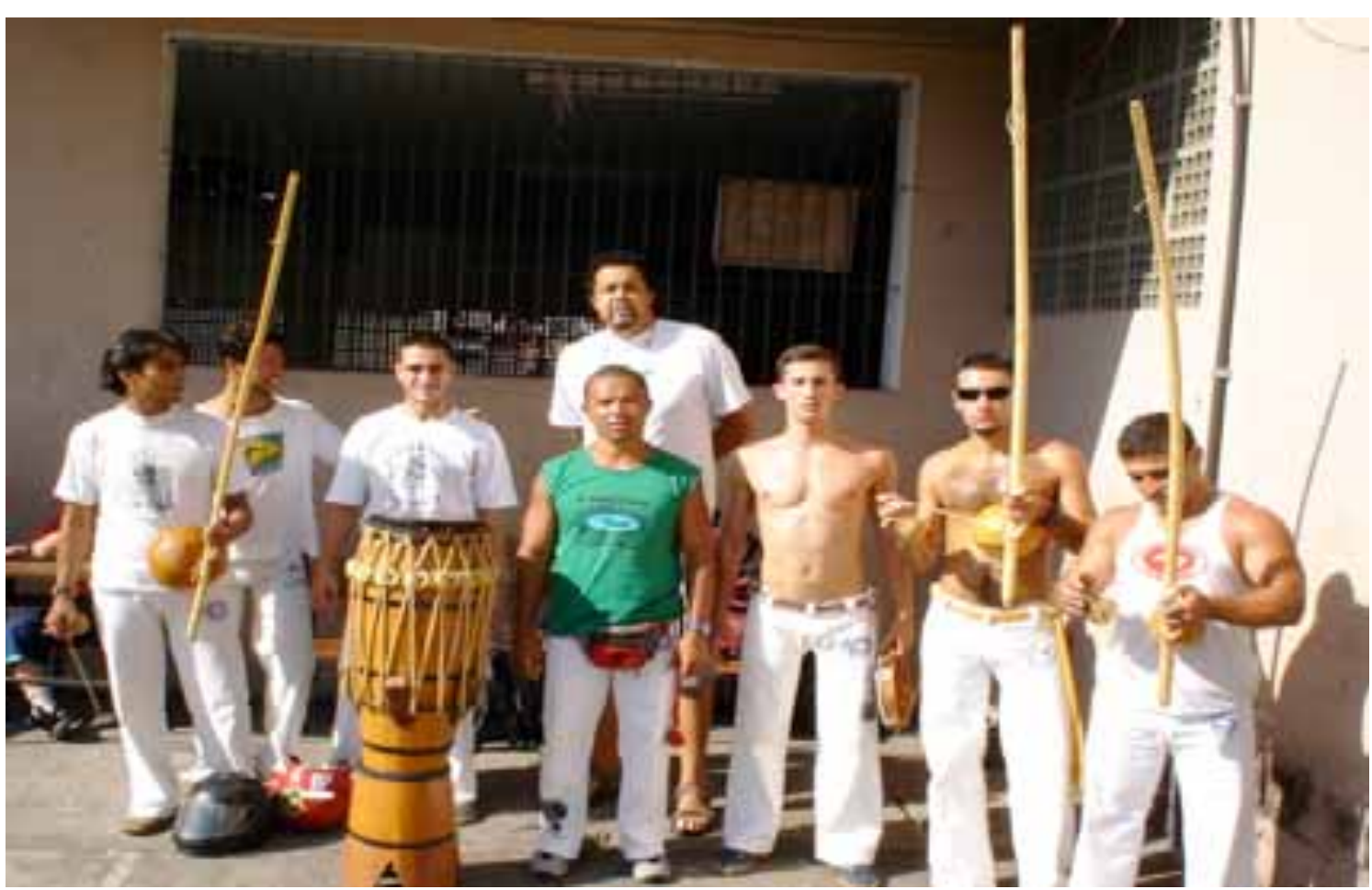

Grupo de professores e alunos de capoeira participantes das atividades esportivas aos fins de semana na escola 


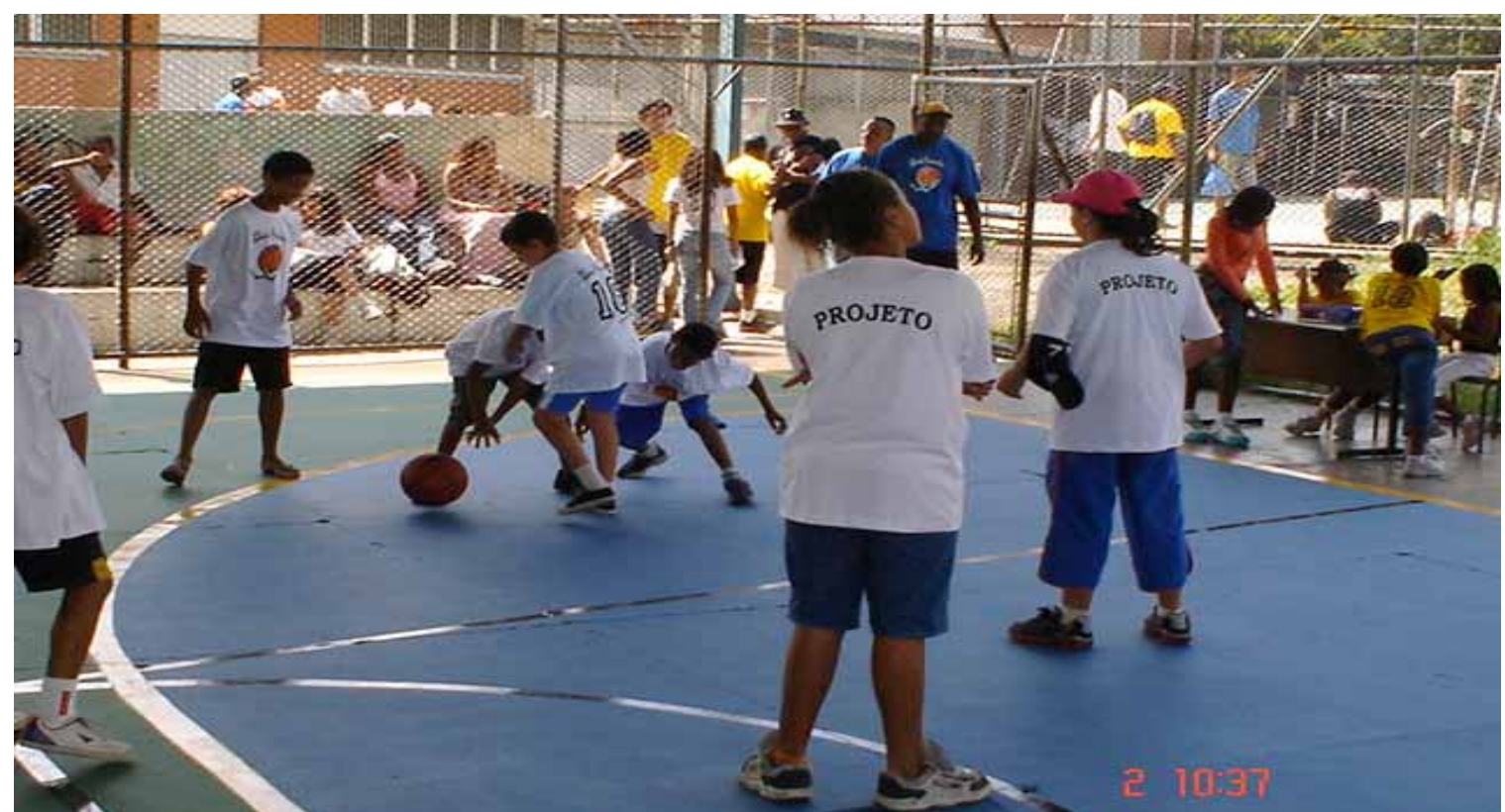

Alunos em aula de basquete realizada aos fins de semana na quadra da escola

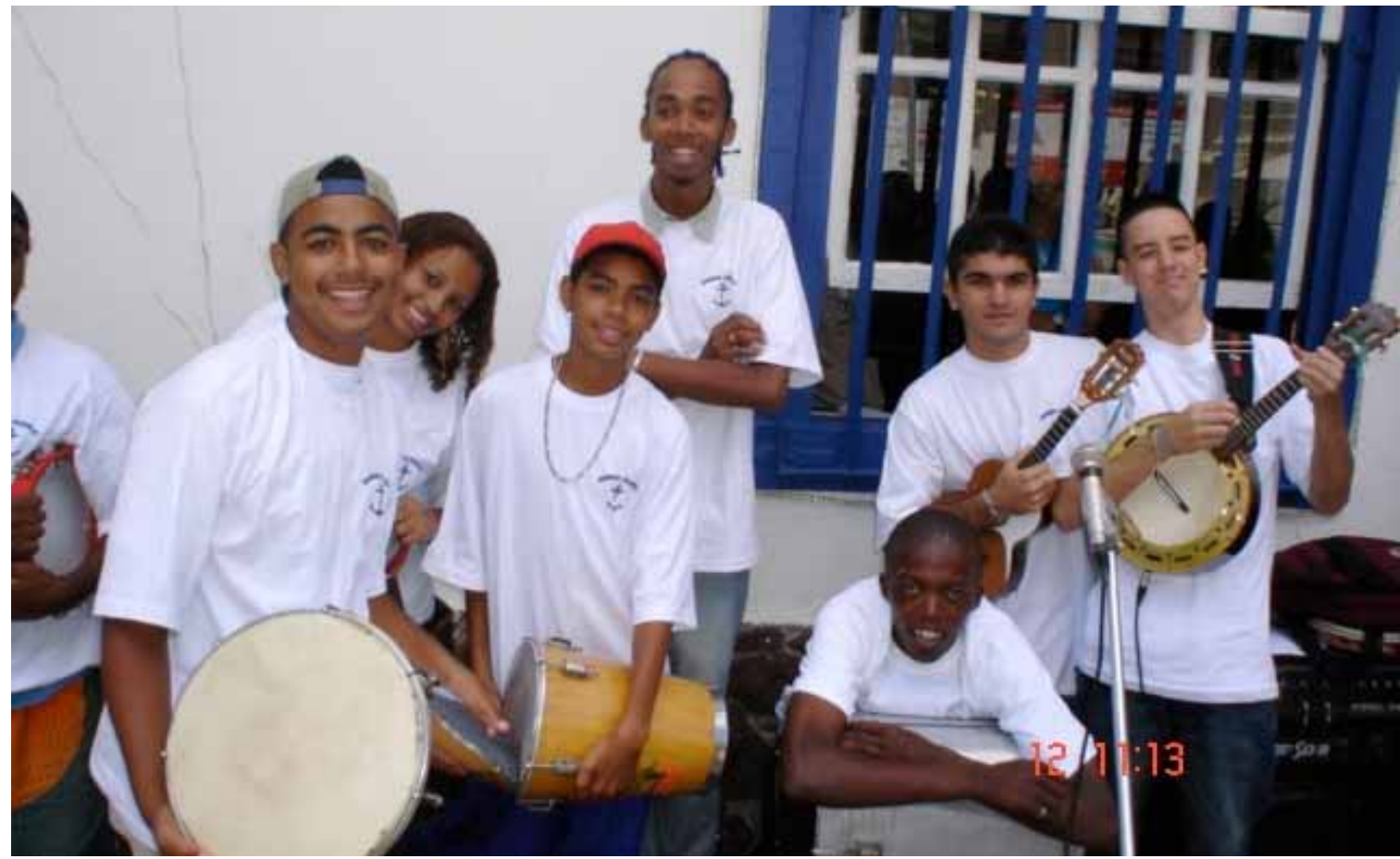

Grupo de alunos integrantes das aulas de cavaquinho e percussão realizadas na escola

Este movimento de abertura da escola para a comunidade indica, ao menos, o objetivo de fazer com que a escola se tornasse um espaço público concreto de realização das próprias ações da comunidade. Arendt (1992) chama a atenção exatamente para o fato de que a ação política e o espaço público prescindem da condição de sujeitos livres e, portanto socialmente iguais. O espaço público, assim, requer dos seus agentes a participação na vida social, política, o que se traduz neste caso, na ocupação e utilização do espaço-escola como realização de interesses coletivos. Quando indagada, a supervisora de ensino da escola a 
respeito da relação escola-comunidade, afirma que este processo possibilitou o crescimento pessoal-profissional daqueles que se envolveram:

As pessoas que se envolveram com a comunidade, este movimento, esta militância - não política, mas de cidadania - que vão nas (sic) festas da comunidade, elas avançaram muito. $\mathrm{E}$ aquelas que vivem somente o cotidiano escolar ficaram presas naquela escola de anos atrás.

Isto revela que embora haja um processo de ocupação/utilização da escola em momentos que ultrapassam o horário escolar, nem todos aderem, se engajam. $\mathrm{O}$ fato de ser esta uma ação voluntária deixou a cargo de cada um participar, ou não, do que a escola realiza e oferece. Nesse sentido, foi bastante recorrente ouvir, principalmente de direção/coordenação e agentes escolares, que o corpo docente da escola é o segmento que menos se envolve com estes projetos da escola.

Não haver um envolvimento de grande parte dos professores afeta não só a relação com os alunos como o próprio projeto de uma "escola aberta". A CP A analisa o envolvimento do professor:

Por exemplo, estas festas do Pq. Peruche ${ }^{29}$, quantos professores estão envolvidos? Praticamente nenhum. Quais alunos, então, que ficam sabendo deste trabalho? Então você não atinge os alunos por falta de trabalho em sala de aula. Não é considerado muito importante...mas todo mundo gosta quando sai no jornal, 'que legal, nossa escola!' Mas o que cada um tem feito pra isso é um número muito pequeno.

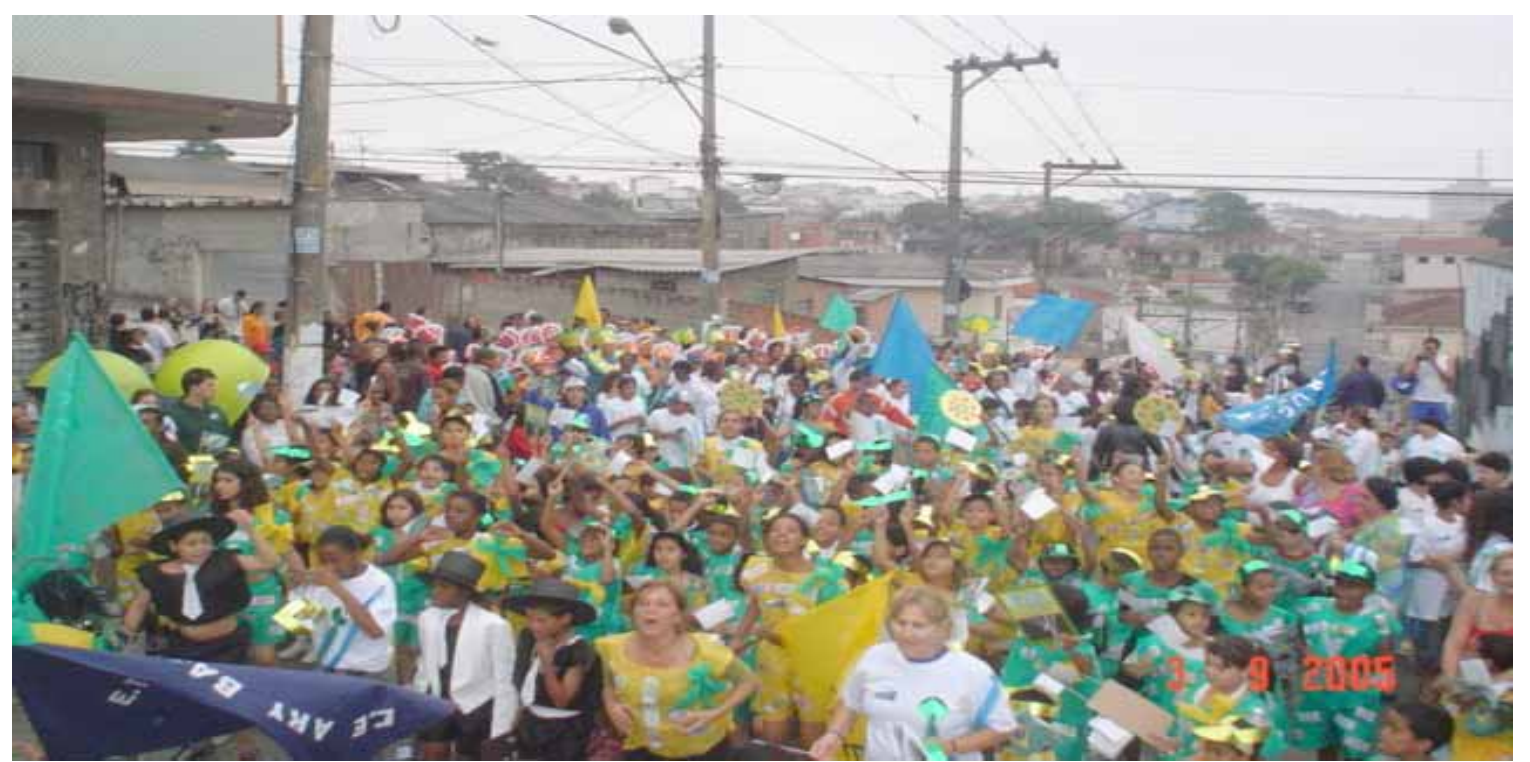

Nas ruas do bairro, integrantes da escola desfilam em comemoração aos 69 anos do Pq. Peruche

\footnotetext{
${ }^{29}$ Aqui se trata dos dois eventos nos últimos dois anos, de comemoração da idade do bairro no qual está inserida a escola. Fui a ambas, é uma festa de rua, com comes e bebes, carro de som, atividades e brincadeiras para as crianças, bolo feito pela comunidade, carro de som, samba, etc. com a parceria das escolas do entorno.
} 
A crítica à falta de envolvimento dos professores revela, por um lado, o corporativismo do corpo docente, mas por outro, que o envolvimento dos professores "oferecido" à comunidade é insatisfatório, na compreensão daqueles que coordenam e dirigem a escola. Embora se tenha visto realmente maior participação dos outros segmentos, sempre que estive em alguma das atividades fora do horário escolar, encontrei, mesmo que poucos, professores participando, prestigiando o evento. A crítica ao baixo envolvimento docente revela ainda as diferenças e conflitos internos ao que se refere à natureza e condições de trabalho docente, que muitas vezes faz com que os professores dobrem ou até tripliquem a jornada de trabalho. Participar de atividades voluntárias, inclusive em fins de semana, nestes casos, talvez beirasse a insanidade.

Quando percorri estes momentos que envolviam a relação com a comunidade, a abertura aos fins de semana e a realização de eventos no bairro ficou claro que os laços sociais de cooperatividade e participação atingem também os alunos, alterando a própria visão que têm da função da escola. Assim diz o aluno A da $8^{\text {a }}$ série:

A comunidade se preocupa com a escola. Quando teve a passeata de 7 de Setembro o diretor vem e pergunta se a gente quer fazer as fantasias pra passeata. Ele sempre convida, pergunta. A escola não é só aquele lugar chato, que você entra, ouve a aula e vai embora. Faz tempo que não é mais isso...

É necessário acrescentar à análise, o movimento inverso, a relação comunidade-escola, o que significar compreender o envolvimento e a representação que pais de alunos, escolas de samba, instituições e lideranças locais têm da escola.

Este aspecto também apresenta suas contradições. De modo geral, há um reconhecimento do trabalho da escola pelos pais, a adesão vem crescendo, etc. No entanto, CPs, assistente e auxiliar de direção observam que é muito difícil romper com a visão cultural paternalista de que a escola pública é o braço provedor do Estado e de que o papel das famílias pode/deve ir além da freqüência às reuniões de pais ritualizadas nos finais de bimestre. A CP A afirma:

A participação dos pais vem crescendo. A questão de não pichar, de cuidar, de ser referência de outras escolas do bairro...mas ainda falta chegar em questões mais decisivas da escola, como a questão pedagógica. Eu sinto a comunidade, os pais ainda um pouco distantes disso. Procuro chamar os pais, pra discutir outros assuntos, pra discutir temas. Mas são poucos que vem. Não é significativo. A comunidade peca um pouco nesta área. 
A professora de Informática, por outro lado, considera que é o projeto da escola que ainda não conseguiu atingir este nível democrático de gestão, chamando alguns pais e alunos para participar da elaboração do PPP, da composição do currículo e das diretrizes do trabalho pedagógico no início do ano letivo.

O impasse em conseguir trazer a comunidade para dentro da escola é, segundo o assistente de direção, fruto de uma cultura escolar calcada no paternalismo estatal:

Esta comunidade foi mal acostumada. E nós não resolvemos isso até hoje. A pergunta é sempre: o que que você pode fazer por mim? Posso usar a água, a luz, seu prédio? O que você vai dar pra mim? Aqui não, o diretor é o responsável, eu posso usar, gastar, e o diretor tem que arrumar, deixar limpo, fazer a manutenção para que eu use. Agora então, que estão dando roupa (uniforme), merenda, nós estamos perdendo. Eles têm uma visão muito assistencialista.

Outro aspecto bastante recorrente na fala dos funcionários da escola é a própria expectativa, o que se espera da escola por parte da comunidade. Nesse sentido, não raro se evidenciou a lacuna histórico-cultural entre aquela escola que os pais (quando muito) estudaram e aquela que seus filhos estudam. A inserção da mulher/mãe no mercado de trabalho e a reconfiguração das relações familiares, a ausência, muitas vezes, de um adulto dentro de casa, a baixa escolaridade dos pais, da diferença dos valores e capital cultural foram apontados como elemento dificultador da relação dos pais com a escola.

Resultante desta lacuna social e histórica está a percepção por parte daqueles que trabalham com educação de que tais famílias, muitas vezes, procuram "enxergar" na escola o tempo-espaço capaz de "solucionar" os desafios e dilemas que as famílias contemporâneas vivem por conta de todas estas mudanças. A agente escolar D se refere aos pais, quando interrogada sobre qual era o papel da escola, nos seguintes termos: "Têm pais que não estão nem aí. Não aparecem na escola. Tem pai que põe o filho na escola pra se ver livre do filho! Pra eles o filho é um problema e pra gente que já tem tantos (alunos)...”. A professora A também expõe este problema: "às vezes, tem dias que parece que estamos somente tomando conta dos alunos, ajudando as famílias a cuidar de seus filhos".

Quando conversei com a direção sobre esta relação família-escola, um dos primeiros pontos levantados foi exatamente o fato de que estas mudanças afetavam a própria função social exigida para a escola.

Tem criança que não sabe dar bom dia, pedir licença, ir no banheiro...que não está acostumada porque não tem relação com o adulto. Então esse trabalho é função da escola hoje. Porque a atualidade tira dos pais a 
possibilidade, o tempo dos pais em estar com estas crianças em casa. Não tem adulto como referência, pra conversar, sentar na mesa... Então você vai, pra além do letramento, da alfabetização, pra ter que trabalhar a questão da relação, do limite, da convivência grupal, do estabelecimento de regras...

Como resultante da relação entre esses fatores, o conflito a respeito de qual sujeito se querer formar. Para a auxiliar de direção,

pais e comunidade não sabem o sujeito que eles querem. Isenção dos papéis do pai/mãe...Escuto 'é que eu trabalho o dia inteiro...' aí fica difícil. Que individuo é este que a escola deve formar?

Estas questões "de que sujeito formar", "qual o papel da escola", afetam também o imaginário e a expectativas dos próprios alunos. Quando conversei sobre estes pontos, foi recorrente ouvir que a escola deve "preparar para o futuro", na qual passava pelo ideal de sucesso profissional, através de "vestibular", "tomar consciência do que acontece com o Brasil hoje" como afirmou a estudante $\mathrm{C}$, ou de aprender a reivindicar os direitos. O Aluno B explicita os direitos como: "de ir e vir, de trabalho, receber salário, cesta básica".

Enfim, a relação desta escola com sua comunidade parece estar em um estágio avançado quando comparada a de outras escolas, e isto, muitos professores, que dão aulas em outras escolas, reiteraram. Entretanto, percebe-se mesmo assim, que este movimento é resultante de uma ação muito direta do diretor e do vínculo que este procurou estabelecer com a comunidade, havendo ainda, senão um imobilismo de alguns segmentos, pelo menos, um não-envolvimento. Nesse sentido, as mudanças na concepção e estruturação das relações comunitárias, no seu caráter público passam pelo enfrentamento dos alicerces da cultura escolar no que tange ao imaginário e representação que sustentam a relação escolacomunidade.

Tais mudanças nas concepções de escola e de relação estado-escola-família revela pontos cruciais da encruzilhada pós-moderna. A escola parece nunca ter sido tão moderna, no sentido do que se afirmava no capítulo anterior e que se ratifica na fala do diretor, ao que se refere à tarefa de socializar, civilizar e preparam os indivíduos para viver em sociedade, exercem a autonomia, a cidadania, etc. Um atributo que antes era partilhado com a família se configura em nossa contemporaneidade sob a égide de um individualismo exacerbado, de uma lógica neoliberal estatal, em que coloca nas mãos dos integrantes da escola quase toda esta tarefa e função educativa, independente das condições de trabalho e divisão das responsabilidades. Por outro lado, a forte relação entre esta escola com seu entorno parece só ser possível na medida em que se aceita a escola como pólo aglutinador das demandas 
políticas da comunidade, ou seja, de que é nesta relação micro-social que se constitui o próprio exercício de cidadania e a participação política.

\subsection{Da relação com o conhecimento - professores, alunos e atividades (extras) classes}

Ao que se refere a relação professor-aluno com o conhecimento, considerar-se-á desde os diversos saberes que permeiam o trabalho docente, as inúmeras atividades desenvolvidas em sala de aula e fora dela e da escola até o que se (re)produz enquanto conhecimento socialmente compartilhado. Tomar-se-á como base de análise as observações de campo, entrevistas e análise do plano de ensino de alguns professores do Ensino Fundamental II.

Será também momento de investigar como o currículo da escola atravessa a prática pedagógica de seus agentes articulando as atividades que ocorrem dentro da sala de aula às atividades extra-classes, o que incluiu, não só as visitas a museus, exposições, parques, etc., mas também as próprias atividades esportivas e culturais que ocorrem também aos fins de semana.

Não por acaso, portanto, escolhi deixar este tópico para depois daqueles da gestão escolar e da relação com a comunidade. A escolha da estruturação do texto desta forma se justifica, sobretudo, pelo fato de que ao longo da trajetória desta pesquisa de campo, percebeu-se que a relação professor-conhecimento-aluno se encontrava alicerçada diretamente ao trabalho de gestão da escola e de sua relação com a comunidade. As palavras da professora B que chegara à escola neste ano letivo, ao comentar a respeito do que norteava a ação daquela escola, elucidam o que se quer dizer e indica por onde investiu centralmente o corpo diretivo da escola:

Talvez o projeto da escola seja a articulação com a comunidade. Há uma articulação de todas as áreas. Os projetos da escola estão interligados, convergem com os interesses da comunidade... Eu nunca vi uma relação assim, com esse entrosamento. A escola cuida da comunidade e a comunidade cuida da escola...É uma experiência nova.

O currículo escolar em ação, por muitas vezes, é a própria relação que a escola enquanto gestora de relações humanas estabelece com sua comunidade, o que, sem dúvida, acarreta consequiências para o ensino e o trabalho do professor.

Além do que foi dito a respeito do investimento no contato com a comunidade, a supervisora de ensino, que já trabalha com esta escola desde 1998, revela aspectos importantes do porquê deste movimento para além das paredes da sala de aula: 
A escola procurou investir na formação dos professores para uma mudança da prática. Mas, em vista do investimento, não surtiu muito efeito. Por conta disso, o diretor foi trabalhar com a comunidade, para além dos muros. Ele começou a investir na gestão com a comunidade, com as parcerias, pais, escolas de samba.

Mas como isso interfere no currículo da escola? Como a gestão escolar e o vínculo com a comunidade afetam o trabalho em sala de aula? Há uma efetiva articulação das "esferas" comunidade e sala de aula ou seria mais uma adaptação da segunda à primeira? Os alunos "aprendem (mais e) melhor" por conta da gestão democrática nas relações e da ampliação do currículo? O que ocorre em sala de aula? Como é a relação professor-aluno? O que se ensina e o que se aprende? O que dizem os professores? E os alunos?

$\mathrm{O}$ que norteia o trabalho em sala, em tese, é o próprio tema do PPP, o mundo do conhecimento e o conhecimento do mundo que, neste ano, teve como subtema solidariedade e paz. Ao conversar com a CP B ficou claro ainda que o tema do PPP é um trabalho projetado e desenvolvido pelos professores a partir do que eles chamam de Projeto de Linguagem que ocorre duas vezes por semana conduzido na e pela professora da sala de informática. Após o planejamento das ações e atividades, os professores trabalham, com seus alunos, os temas prédefinidos e utilizam as aulas de informática como ferramenta de pesquisa e apresentação dos trabalhos. O grupo de professores utiliza os encontros semanais para planejar, debater e avaliar as atividades desenvolvidas.

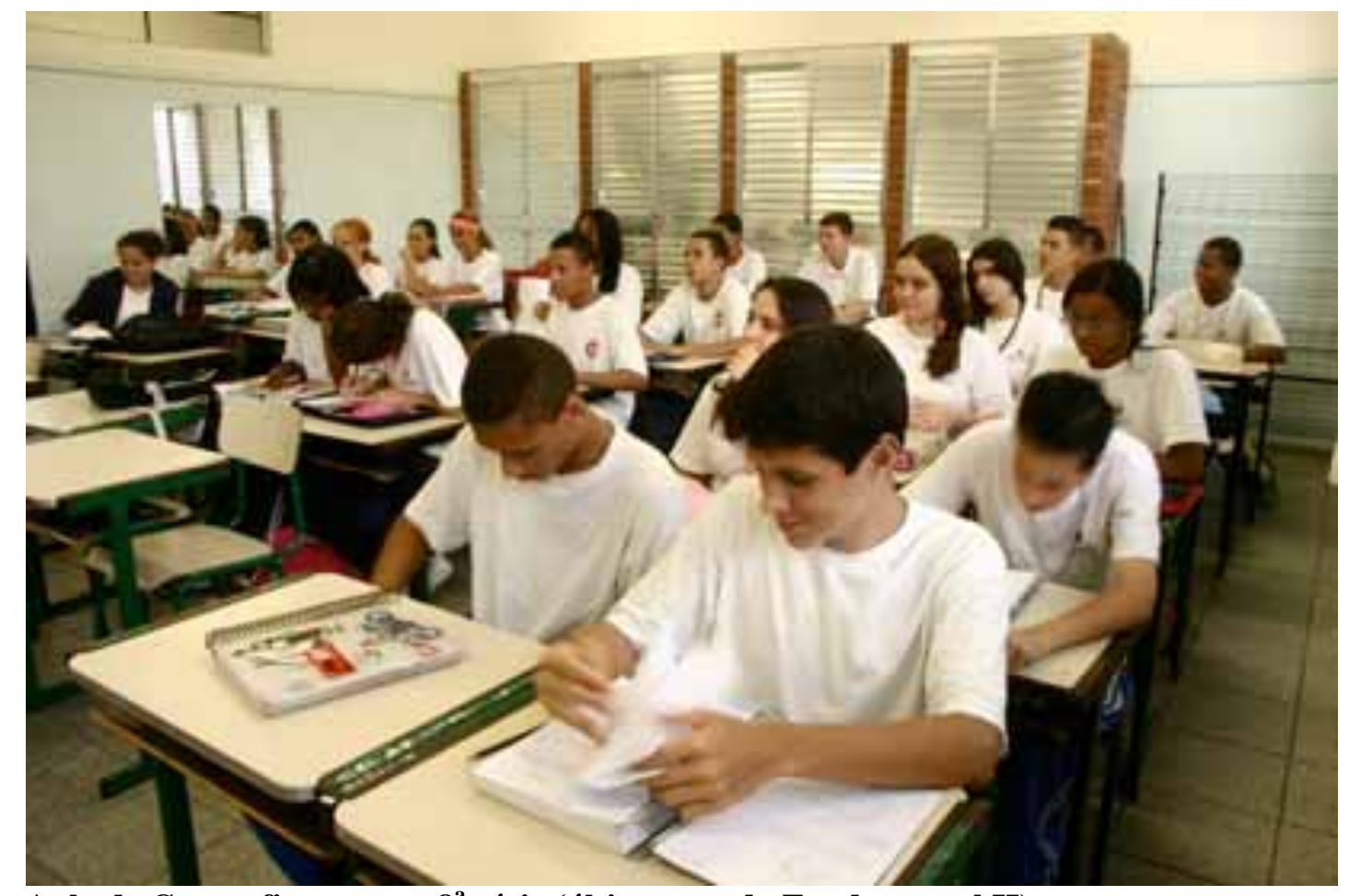

Aula de Geografia em uma $8^{a}$ série (último ano do Fundamental II) 
Ao entrar em sala de aula, assistir algumas aulas de alguns professores, estava curioso para ver como a relação professor-conhecimento-aluno se desenvolvia. Haveria algum diferencial? Algumas coisas chamaram atenção, seja pela singularidade, seja exatamente pela repetição. Tomando alguns eventos, acontecimentos e práticas de sala de aula pode-se ter um bom início para compreender a complexidade do currículo materializado nas relações de ensino-aprendizagem.

Ao assistir aulas no EFI, (na $2^{\mathrm{a}}$ série), a didática se centrava na professora dando seguidos exercícios aos alunos e fazendo a correção coletivamente. Quando a maioria acabava, começava a corrigir, pedindo para que cada aluno falasse a resposta. Após corrigir, nova distribuição de folhinhas xerocadas com a atividade e os alunos tornavam a fazê-la. Não consegui identificar o que sustentava, ligava um exercício ao outro, o que por muitas vezes, sugeria mais uma atividade recreativa do que de fato, de alfabetização, letramento, etc., que era o que a professora havia dito ser seu foco central de trabalho. Entretanto, também dissera que a "questão do lúdico" lhe era fundamental, pois assim ia "conquistando mais seus alunos". Nesse sentido, crê-se que tentava, através do lúdico, trazer o aluno para a resolução das atividades. Na fala desta professora (e), quando questionada sobre quais eram seus principais desafios, empecilhos e facilidades no trabalho como docente, se evidencia as dificuldades pela qual passa a escola para alfabetizar todos os seus alunos e sua relação calcada em linhas pedagógicas de cunho construtivista do "aprender a aprender" (Duarte, 2001).

Eu me preocupo sempre em atender às necessidades de cada um. Eu encontro muita dificuldade quando a sala tem muitos níveis diferentes de aprendizagem, e isso dificulta o trabalho. Às vezes eu tenho alunos que já lêem, já fazem atividades sozinhos e tenho alunos que não conseguem, então eu tenho que buscar atividades que eles consigam realizar ou sozinhos ou com o meu auxílio. O que eu preciso fazer é que eles consigam ler, escrever, calcular, e colocar em isso em prática no dia a dia deles.

Nas aulas do EFII a participação e o trabalho do aluno eram ainda mais requisitados. Não foram poucas as vezes que se pôde notar alto grau de participação dos alunos nas aulas. Deparei, por exemplo, com poucas aulas na qual o professor utilizava a lousa para "colocar" o conteúdo, a matéria e depois explicá-la. Em muitas delas, os alunos foram "exigidos" a participar, seja através de debates, seja através da execução de alguma atividade individual ou em grupos. Pesquisas, atividades com revistas, leituras coletivas, produção de textos, foram recursos didáticos bastante utilizados pelos professores dos quais freqüentei as aulas. Se seguir a tipologia de Saviani (1997a), anteriormente mencionada, a escola procura superar a 
pedagogia tradicional, na qual o aluno é mero receptor do saber transmitido pelo professor para a pedagogia da escola nova, recebendo as proposições da linha construtivista, na qual aquele, além de mais participativo recebe uma atenção mais individualizada.

Entretanto, com isto não se quer dizer que houvesse participação geral da classe sempre. Em muitos momentos alunos que nada faziam, professores que tardavam quase 10 minutos para estabelecer uma ordem mínima de comunicação em suas aulas, dispersão excessiva de parte dos alunos, entrada de funcionários para dar aviso ou de alunos para pedir livros emprestados, faziam parte da dinâmica cotidiana das salas de aulas.

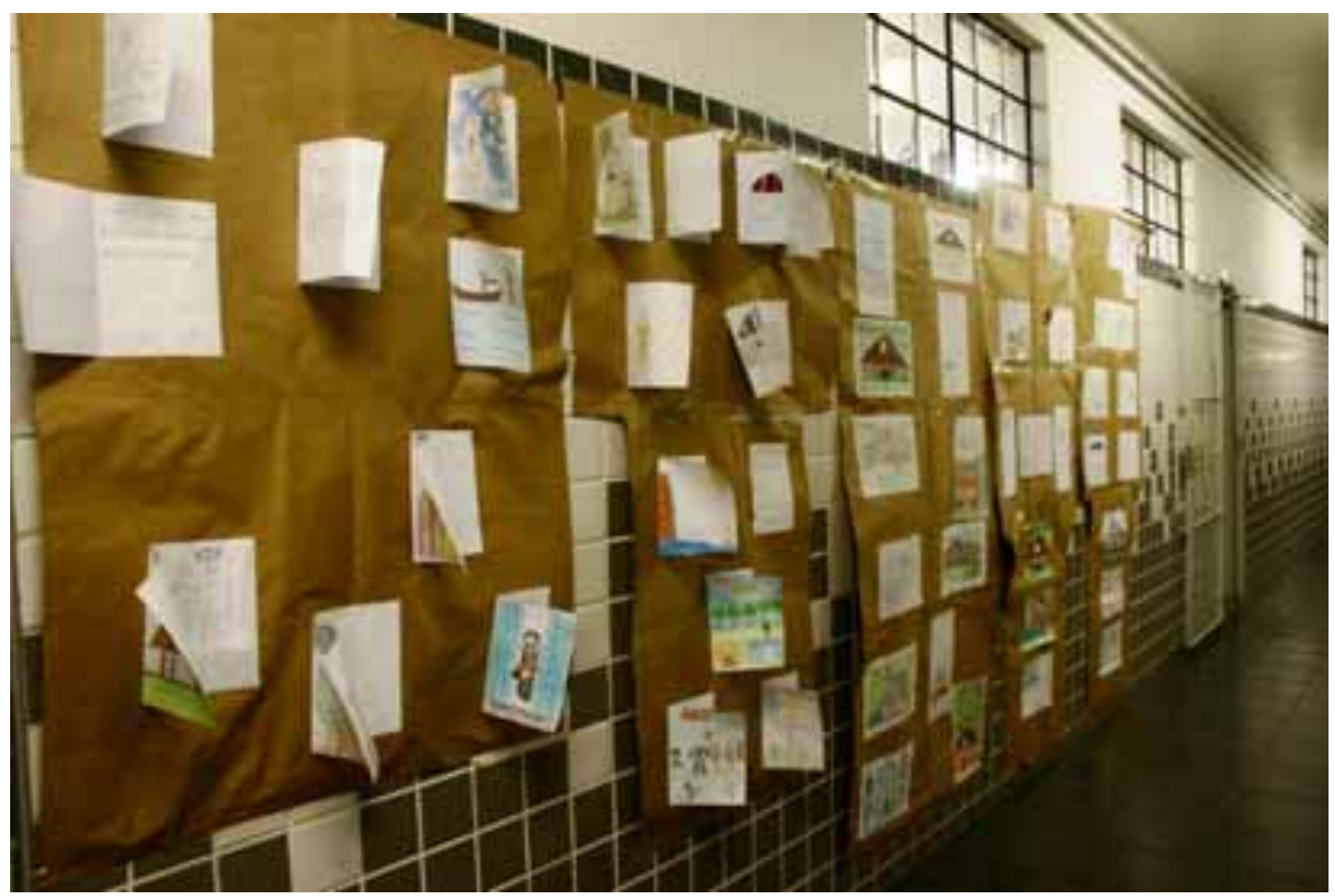

Exposição de trabalhos do Fundamental II nas paredes dos corredores do prédio

Ao ter acesso aos planos de ensino de alguns professores, geralmente daqueles que assisti às aulas, pôde-se notar, além da preocupação com o ensino dos conteúdos científicos, históricos, gramaticais etc. já consolidados, também a atenção a outros conhecimentos e atividades didáticas. Ficam previstas, desde o plano de ensino, atividades culturais como idas ao cinema, museus e teatros, assim como a articulação de atividades entre Português e Sala de Leitura e das disciplinas com os temas e atividades planejadas no Projeto de Linguagem (na Informática).

Curioso notar nos objetivos do plano de ensino, como por exemplo no de Ciências, a preocupação desde o "reconhecer que as descobertas científicas foram feitas por pessoas iguais a nós, porém curiosas e que pensavam de forma organizada", até "reconhecer a Célula, Tecidos, Órgãos e os Sistemas que compõem nosso organismo”. Ou seja, confluía o Cientista 
e a Ciência; sujeito e objeto do conhecimento em uma mesma trama mantém o compromisso com os conteúdos clássicos, mas abrindo às críticas pedagógicas que exploram as variáveis determinantes do, então, saber científico. Assim afirma a professora (a) da disciplina: "antes ao estudar Einstein, eu queria que eles soubessem a teoria da relatividade, hoje quero que ele conheçam a pessoa, a vida do físico."

Outro aspecto bastante abordado pela escola refere-se ao que se pode chamar de temas que afetam a adolescência e juventude, como uso de drogas, sexualidade, higiene pessoal, vestibular, etc. Em uma aula de Ciências que participei, os alunos faziam e apresentavam para a classe, cartazes a respeito das diferentes drogas, seu uso e consequiências. Numa outra aula ministrada pela $\mathrm{CP} \mathrm{B}$, a $8^{\mathrm{a}}$ série lia e debatia um "manual" fornecido às escolas municipais sobre educação sexual dos meninos.

Parece haver uma preocupação da escola em organizar seu currículo para além da prática desenvolvida individualmente pelos professores e da restrição dos conteúdos científicos "clássicos". Busca-se assim, não só trazer novos conteúdos, experiências e atividades, mas também articulá-los a um eixo norteador que é regido pelas ações desenvolvidas na sala de informática.

Por conta disso, ao final do primeiro semestre, na véspera das férias, houve uma reunião de professores e coordenação pedagógica para apresentar o que cada professor estava desenvolvendo interdisciplinarmente sob o eixo temático do PPP. Como forma de trazer as impressões ao final do encontro gostaria de reproduzir um pequeno trecho de minhas anotações:

\begin{abstract}
A apresentação dos professores mostrou um certo envolvimento de muitos com o PPP. Muitos buscaram articular conteúdos 'clássicos' a outros recursos didáticos - informática, leitura, etc. Houve por parte dos alunos grande busca na internet e produção de materiais. O objetivo geral do encontro é socializar com os pares o que estão realizando em sala de aula/informática.
\end{abstract}

Vale notar aqui, que o caráter geral do encontro era de comunicar aos seus pares, coordenação pedagógica e direção, o que cada professor estava fazendo com seus alunos, o que significa, de certa forma, que a maioria dos professores não estava a par do que o outro estava desenvolvendo. Isto evidencia, por um lado, as dificuldades que os professores/escola têm de articular coletivamente o trabalho e os conteúdos de sala de aula, quanto por outro, as contradições do "discurso pedagógico oficial" do PPP com o que de fato se realiza.

As idéias pedagógicas defensoras da necessidade de trazer os "conteúdos experienciais do aluno" para o trabalho de sala de aula, se confrontavam com a prática de ensino, por vezes calcada no que o livro didático requeria. Uma aula de Geografia de $7^{\mathrm{a}}$ série reflete bem isso. 
Ali se conduziam duas atividades, uma de correção de exercícios feitos em casa e depois outra, de atribuição aos alunos da confecção de pequenas bandeiras dos países latino americanos para expor em um grande mapa cultural da América na Feira Cultural que se aproximava. A correção da atividade correspondia especificamente a fazer com que os alunos “soubessem” identificar a região dos Grandes Lagos, na região nordeste dos EUA (com o nome e a localização geográfica de cada um deles). Não parecia haver articulação e correlação da seqüência didática da atividade de correção com as finalidades de produzir e apresentar à escola, um "panorama" das culturas latino americanas.

O fenômeno aula, muitas vezes, parecia um evento aberto, indeterminado, suscetível a diversas interferências internas e externas. Correções que se interrompiam pela metade por conta do tempo, aulas que começavam com aquela clássica pergunta, "onde foi que paramos?", situações de "desordem didática" na qual se começava um debate dentro de outro, falta de planejamento ou excessivo improviso constituía com certa frequiência o cotidiano das salas de aulas. Numa aula da $5^{\text {a }}$ série, a professora conduzia uma conversa com os alunos até que perguntou "o que era democracia", pediu que um checasse no dicionário o significado. Em seguida perguntou "o que era uma narrativa". Já sem entender onde queriam chegar, escutei ao final, que ela buscava "ir estimulando os alunos a responder e depois costurava os temas..."

A partir das aulas observadas e dos planos de ensino de alguns professores, muito do que se acordava no PPP, a pretexto da amplitude e abrangência do tema $o$ mundo do conhecimento e o conhecimento do mundo, abrir-se-ia margem para que "qualquer assunto" ou conteúdo coubesse. Por conta disso, muitas vezes o que se pôde notar foi uma adaptação dos conteúdos acordados - e aqui se entende, sobretudo, os temas que aproximassem o currículo escolar ao conteúdo experiencial do aluno, como história e cultura do bairro, a presença do samba na comunidade, cultura popular, sexualidade, vestibular, etc. - aos tradicionalmente selecionados pelos professores. E que, sem dúvida, por vezes "coincidia" com o do livro didático.

Ao indagar a CP A sobre o fato de muitas vezes não ter visto em sala de aula os acordos do PPP, a busca pelo lúdico, tão reivindicado pela direção da escola, ela afirma:

A gente nota que muitas coisas que são planejadas aqui não acontecem lá (na sala de aula)...Um dos maiores desafios é esse, passar do planejamento pra ação, pra execução. Isso depende ainda da nossa intervenção, que ainda não é vista como uma coisa muito positiva.

Para ela muitos professores têm dificuldade de fundamentar, elucidar e explicitar a razão do quê e como ensina. Assim, ela questiona: 
O professor tem que voltar na questão, no planejamento, no porquê que está dando isso. Ele (o aluno) vai aplicar isso em algum lugar? Tem algum compromisso social? Isso vai servir pra quê? É só porque está no livro didático?... O professor tem que ter claro as necessidades do aluno naquele momento. Tem professor que vê que tem aluno de $7^{\mathrm{a}}$ série, por exemplo, que não tem o conteúdo de $5^{\text {a }}$ série e não quer voltar e trabalhar os conteúdos que o aluno precisa... Porque o conteúdo não pode ser mais importante que a necessidade do aluno!

Isto remete ao desafio de planejamento do trabalho posto ao professorado. Além do trabalho de antes, há o durante e o depois do que ocorre em sala de aula (além do trabalho em outras escolas). Esta compreensão do trabalho do professor leva, muitas vezes, a ignorar as condições reais de trabalho e a supor que as limitações da relação professor-aluno que se sucede dentro da sala ocorre mais por incompetência, desinteresse ou descaso docente do que pela forma pela qual esta sedimentada a profissão e o trabalho do professor.

Nesta questão também está envolvida uma das crises por qual passa a pedagogia e o campo educacional, segundo Libâneo (1996:140): a do reconhecimento social do campo de atividade profissional. $\mathrm{O}$ autor argumenta que ao passo que nunca se falou tanto em valorização da educação, do magistério, a desvalorização do trabalho docente, sobretudo pelas políticas públicas, também nunca foi tão grande. O que afeta necessariamente a conduta docente diante de sua profissão. Libâneo (1996:140) assim argumenta:

Sob o pretexto de baixo salário, e com uma formação profissional deficiente, o professor torna-se um mero cumpridor de obrigações, reduzindo sua auto-estima e comprometendo seu profissionalismo.

Quando entrevistei alguns alunos indagando a respeito da qualidade de seus professores e sobre como é a relação com os professores, de modo geral disseram que os professores são bons, que se preocupam com eles, "procuram dialogar, conversar", que os fazem "pensar no futuro, na sociedade que queremos para nós", "saber o que está acontecendo com o Brasil atualmente", "a ter mais autoconsciência do que queremos para gente" etc. Nesse sentido, vê-se efeito de certos acordos do PPP ao reivindicar uma maior interlocução dos professores com os alunos. Naquele contrato didático escola-alunos, se requeria dos professores que estes "reservassem" algumas aulas ao longo do ano para conversar com os alunos sobre o que lhes interessassem.

Foi possível notar, através da fala da professora B, o trabalho de gestão das relações humanas atingindo o universo da sala de aula: 
Porque é função da escola passar o conhecimento, formar uma pessoa crítica e então você precisa do conteúdo. Mas isso não basta, não adianta saber as fórmulas, e não saber conversar, ouvir o outro. Você precisa dosar conteúdo e relações, valores... Alguns alunos acham que aula de fato é quando tem matéria na lousa. Às vezes eu interrompo pra discutir as relações, as regras, a avaliar o que fizemos, etc.

Quando professores e alunos falam uns dos outros, o caráter de exigência no trabalho do professor é um ponto de convergência. A professora A diz o seguinte:

O professor deve estar preparado. O aluno não quer um professor que não se prepara, que disfarça... hoje há mais questionamentos, interrupções, tolerância. Você não está só pra mandar, mas sim pra trocar, dialogar. Eles não conseguem ficar o tempo todo só ouvindo.

O aluno A, numa resposta perspicaz, a respeito do que mudou para a escola de "antigamente", considera os professores mais preocupados com a profissão.

Antes ele passava a lição na lousa, 'copia tal coisa' e recebe o salário. Hoje eles estão pensando em doutorado. Estão tendo mais consciência, estavam muito acomodados.

Quando o tema é o desinteresse, a falta de compromisso e envolvimento e a própria indisciplina por partes dos alunos o embate professor-aluno se mostra revelador. A professora D ao falar da atual "geração" de alunos, através de um discurso saudosista, identifica um grande abismo sociocultural entre as gerações.

...porque antes as coisas duravam e agora não. A juventude hoje não tem capacidade de organizar idéias, de expressão dos sentimentos. Os alunos não entendem o que é um segmento de reta!! Porque eles não tem vocabulário...a gente vive num mundo desestruturado! Então a gente tenta ajudar eles a ler, a saber interpretar, a usar as ferramentas que eles vão ter pra primeiro entender e depois transformar.

Os próprios alunos reconhecem que muitos entre eles não colaboram. O aluno B afirma que "tem gente que não colabora. Na minha sala tem muita gente que atrapalha, que não quer nada com nada”. Mas contrapõe: “...também, tem poucos professores que instigam a curiosidade dos alunos". O aluno A, quando indaguei qual era o papel da escola, respondeu "foucaultianamente": "formar um cidadão; um cidadão manso, que não vai reivindicar as coisas! Os professores não podem falar coisas que a gente vai reivindicar”.

O investimento na gestão das relações humanas, inclusive na relação professor-aluno é também um dos objetivos da abertura da escola aos finais de semana para oferecer atividades esportivas. Isto porque, segundo a direção, o esporte, o jogo, o lúdico, deve contribuir para 
melhor lidar com a disciplina do corpo e da mente, com o estabelecimento de regras e limites, o que favorece o desempenho dos alunos em sala de aula.

...a gente tem que buscar interditar isso (o fracasso escolar), e a interdição vem através do lúdico, e aqui na escola a gente tem procurado trazer com judô, basquete, karatê, capoeira, futebol, aulas de arte... a dar oportunidade pros meninos, eles tem que fazer coisas que eles se identifiquem e gostem, que tá além da sala de aula, que tá além da disciplina. Mas que também tem disciplina! Como o judô e o karatê, na luta tem regra, tem limite... A gente tem que aprender a conviver em grupo, ter regras e limites e negociar esse limite dentro da convivência que mantém a história, a tradição e a cultura, sem ficar escravo dela e sem cair num laissez faire, que cada um faz o que quer. A gente oferece isso pros meninos e eles têm se colocado, uns não fazem, outros fazem mais de uma atividade, e isso ajuda, que esse menino quando vem pra sala de aula a ter mais disciplina, se interesse mais no português, na matemática. Ele vai aprendendo fora da sala de aula, que é uma vivência da cultura, da sociedade, da arte, a se disciplinar. Logo o conteúdo da sala de aula também melhora, como consequiência e não como objetivo, porque eu educo ele pra se perceber, pra se descobrir, assim ele tem um maior auto-conhecimento.

A escola procura investir bastante em atividades extra-classes, dentro e fora da escola. Uma vez, estávamos na sala dos professores e estava afixado na parede um cartaz com a relação das atividades que haviam ocorrido desde o começo do ano até finais de Outubro. Eram 23 atividades que compreendiam palestras, visitas a museus e peças de teatro e idas a parques ecológicos e passeios em parques de diversão. Em conversa com o assistente de direção, se demonstra o grande investimento do trabalho pedagógico em atividades de formação cultural.

Essa escola fez 80 passeios ano passado! Se você pegar um aluno que está aqui desde a $1^{\mathrm{a}}$ serie ele já fez tudo que é passeio. Zoológico?, 'já fui', MASP?, ‘já fui 5 vezes', Museu do Ipiranga? '3 vezes'...então, é um aluno diferenciado.

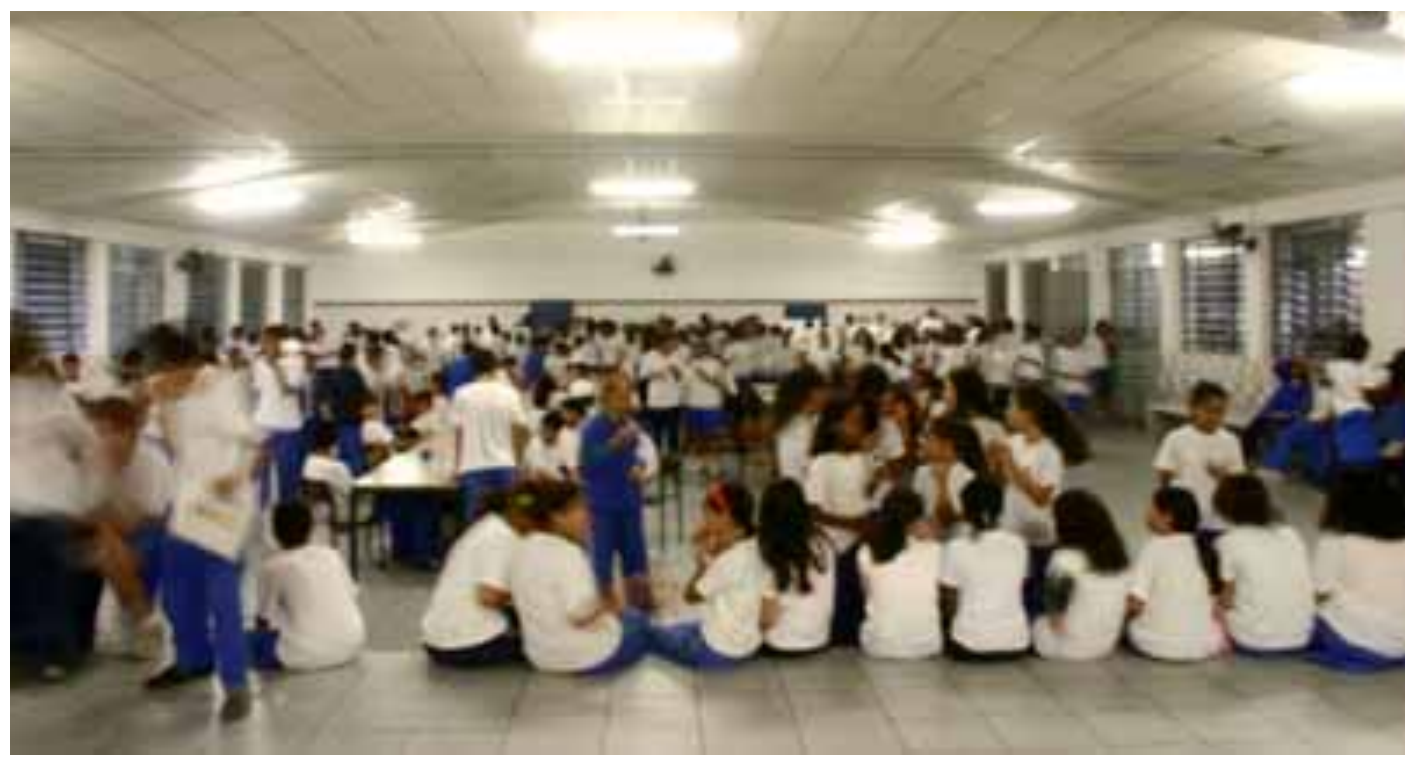

Alunos na hora do intervalo no pátio coberto da escola 


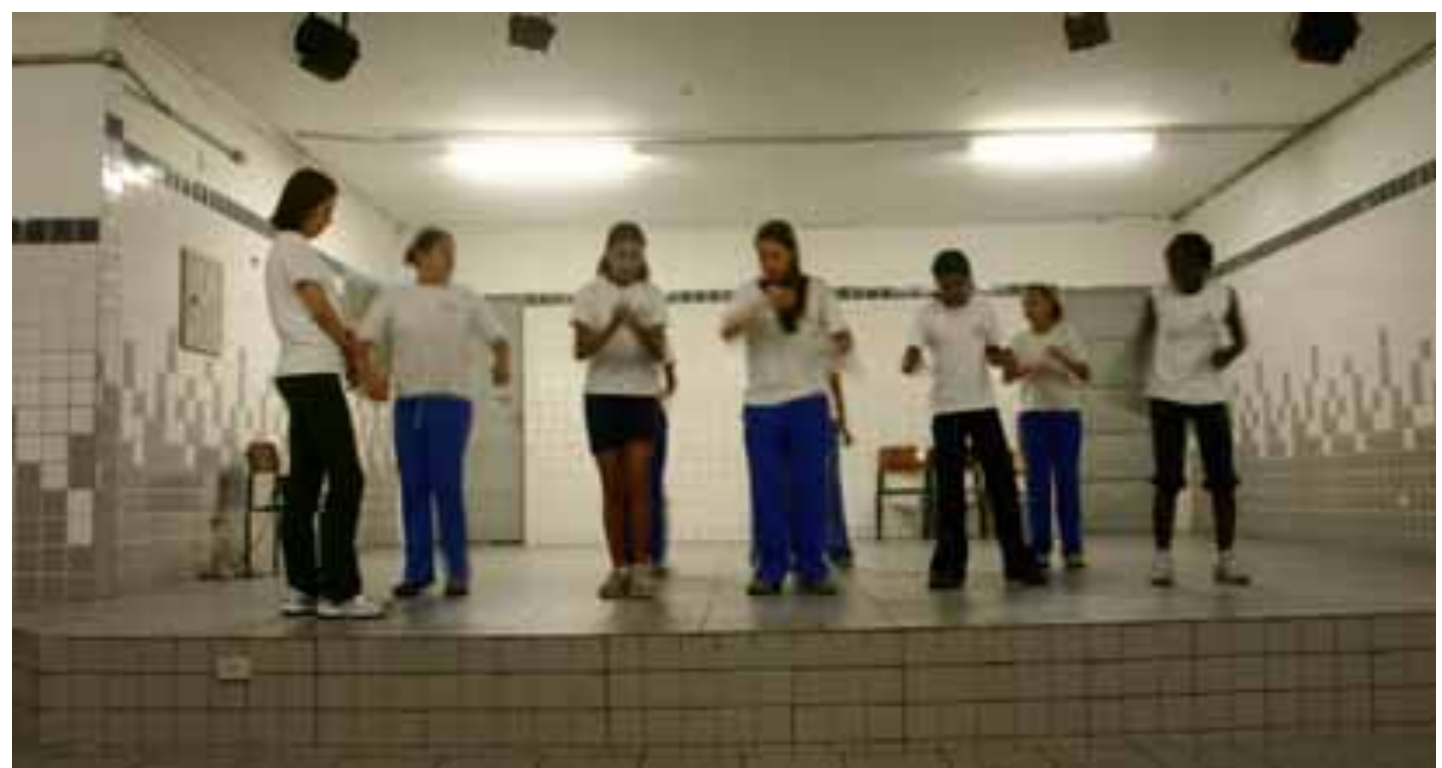

Alunas, junto à professora, ensaiam apresentação de dança para o final do ano

Entretanto, esta escola não foge à regra do que vem ocorrendo com a maioria das escolas municipais de São Paulo e das redes de ensino que implantaram os Ciclos básicos de aprendizagem, que é, entre outras coisas, fazer com que os alunos saiam do Ensino Fundamental com o domínio da leitura e escrita de forma satisfatória. É evidente também que o problema social de muitas redes de ensino dos diversos estados brasileiros que têm apresentados números preocupantes com relação ao nível de alfabetização passa sobretudo pela questão da massificação do acesso ao ensino, não coadunado com uma melhoria na formação docente e da estrutura escolar capazes de dar conta do aumento da demanda. Libâneo (1996:138) ratifica o descaso das políticas educacionais: "as políticas setoriais da educação e os planos elaborados até hoje não só não conseguiram firmar a prioridade efetiva do setor educacional no conjunto das políticas públicas, como também não foram suficiente para modificar a face do sistema de ensino".

No entanto, na sala de aula, a professora $\mathrm{C}$ de $8^{\mathrm{a}}$ série, preocupada com esta questão de uma alfabetização satisfatória reage afirmando: "Então comecei a investir no (trabalho com) texto. Porque eles têm grande dificuldade aí, eles lêem e não sabem o que lêem". A agente escolar D também sente o efeito deste processo e critica os Ciclos e o trabalho do professor: "o ensino está muito fraco, tem aluno da $4^{\mathrm{a}}$ série que não sabe escrever!” Mesmo não sendo possível incursionar sobre a problemática dos Ciclos na rede de ensino paulistana, por aí se vê as tensões, conflitos em relação a sua implantação, resistência e absorção pela cultura escolar. 
Quando acompanhei os conselhos de classe, momento no qual os professores se reúnem para debater o desempenho dos alunos ao longo do ano, a maior queixa que aparecia (no Ciclo $\mathrm{I}$, ou seja, $1^{\mathrm{a}}$ à $4^{\mathrm{a}}$ série), se referia à incapacidade dos alunos saberem compreender o que liam, a escrever sobre o que era solicitado e a dominar as regras básicas de matemática. Por outro lado, foi possível notar, além destes critérios avaliativos para reter ou não o aluno ao final de cada ciclo, a preocupação com a idade, a relação com a família, a condição de moradia e o contexto social. Ao final, naqueles conselhos de classe, notei que por volta de $15 \%$ a $20 \%$ dos alunos eram retidos.

Um outro desafio colocado à prática docente e que sofre também com os efeitos da forma como os Ciclos de aprendizagem foram implementados na Rede Municipal é a questão de atrair o interesse e a participação do aluno dentro da sala de aula quando se sabe que, independente do que ele faça, ele provavelmente não será retido. Quando perguntei à professora B sobre quais eram seus principais desafios como professora daquela escola a resposta foi sintomática:

Fazer com que eles se interessem em vir pra escola pra aprender. Uma parte deles. Eles gostam de estar aqui, mas na sala de aula a concentração não é obtida... os Ciclos também dificultam, porque eles sabem que vão passar de qualquer jeito. Além, pelo fato de serem jovens, não ter muita consciência. Porque aprender é algo sofrido...

Isto ajuda a elucidar o dilema que muitos professores vivem diante do antigo debate pedagógico, trazido através de Saviani (1997a) - a pedagogia tradicional e a pedagogia da escola nova -, que ora insiste na importância dos conteúdos, dos conhecimentos historicamente produzidos, ora na relevância de investir nas relações humanas, na implantação dos contratos sociopedagógicos, e sobretudo na discussão sobre regras, normas e valores. Embora se tenha notado que o "discurso geral" da escola tenda claramente para o lado da última alternativa, sobretudo, porque o discurso predominante é o da direção/coordenação (e que influencia fortemente o discurso dos outros funcionários - agentes escolares e equipe administrativa), há uma parcela dos professores que resiste (mesmo com o discurso pedagógico apontando para outra direção), uma outra que adere mais facilmente, enquanto que outra se encontra na encruzilhada. A fala da mesma professora B é enriquecedora e ilustrativa desta problemática que permeia o trabalho docente na escola.

Estou num momento que eu estou me perguntando isso. Antes eu achava que o importante era ensinar o conteúdo. Comecei a perceber que não. Se eu ensinasse a eles a ter autonomia, a participar de outras coisas, que ia chegar uma hora que mesmo que você não desse aquele conteúdo, eles 
iriam ter condições de buscar sozinhos. E agora me pergunto... só isso também não dá! O conteúdo ainda é importante. Se você não der o conteúdo você ainda está excluindo... E eu estou neste grande dilema. A consciência pesa. Se você aperta de um lado, ela pesa do outro. Se você não dá alguma coisa que acha importante, você se cobra porque não deu.

Além do que foi dito, vale ainda colocar algumas dificuldades manifestadas pelo professor para a realização de seu trabalho, questões de ordem tanto estrutural quanto contextual. As condições de trabalho, os baixos salários, a falta de material de apoio pedagógico estiveram presentes naquilo que se viu, ouviu em entrevistas e conversas de corredor. A professora D sintetiza o embate entre as aspirações de ascensão social e as difíceis condições de trabalho:

O difícil é que tem que dobrar o período, buscar outras realizações, pós (graduação), consumo, aumentar o salário. Tem que dar muitas aulas, fica muito corrido. Falta tempo pra planejar. É difícil, tem que reservar o Domingo... Falta material didático - revista, jornal. Não tem como exigir muita coisa dos alunos.

Libâneo (1996:165/6) assim, analisa a condição profissional pela qual passa o professor da escola pública de hoje, tocando nas debilidades estruturais de formação, no descompasso de capital cultural entre o que se oferece e o que se necessita destes agentes sociais e na própria precariedade da profissão diante das inúmeras mudanças sociais e tecnológicas contemporâneas:

...nossos professores sequer dispõem dos requisitos de formação geral, habilidades de raciocínio flexível, visão estratégica, etc., competências necessárias para dominar procedimentos tecnológicos. A atividade pedagógico-docente é um tipo de trabalho em que coexistem práticas marcadas pela precariedade profissional, pela improvisação. Pelas suas condições de trabalho e salariais, o profissional do magistério é um profissional "separado" que vive várias vidas. Ele compartilha do mundo cultural e científico, mas as condições salariais e de trabalho não possibilitam que participe do mundo da produção cultural e artística, do mundo das teorias e dos discursos...é um difusor de cultura e, ao mesmo tempo, um consumidor acrítico da informação eletrônica...

Os aspectos sociais e pedagógicos da escola até aqui abordados apontam para o entendimento de que as ações gerais do currículo, a atuação da equipe gestora, do trabalho de professores e agentes escolares atinge muito mais na ordem das relações humanas, a gestão democrática, participativa, cidadã - da abertura da escola para a comunidade, da abertura aos fins de semana e a oferta de atividades culturais e esportivas, da sistemática preocupação cultural do aluno, etc. - do que em profundas alterações do que ocorre em sala de aula. O que faz interrogar se não reside no "investimento nas relações humanas" em seu caráter cidadão, 
sua democratização e autonomização, - com a abertura da escola para a comunidade, maior participação de alunos, agentes escolares e professores nos rumos sociais e pedagógicos e a oferta de inúmeras atividades culturais e esportivas - a questão central que faz mover o sentido, o significado que esta escola, dentro do contexto social contemporâneo brasileiro coloca para si? A questão democrática e um ensino para a cidadania podem ser considerados como a base do currículo com a qual se depara esta escola na encruzilhada pós-moderna?

É hora de ver então como aqueles que compõem a vida da escola, que a fazem "mover" cotidianamente, compreendem, elaboram, concebem o papel e o sentido da instituição da qual fazem parte, da qual suas vidas não fariam sentido (pelo menos não seria o mesmo) sem este vínculo, social, comunitário, profissional e/ou pedagógico.

\subsection{O papel e sentido da escola na contemporaneidade para seus integrantes}

A experiência de acompanhar o ano letivo de uma escola pública de Ensino Fundamental de São Paulo, estabelecendo vínculos, conhecendo pessoas, confrontando idéias, desconstruindo saberes, desvelando "verdades", captando "teorias pedagógicas" que embasam o trabalho de seus agentes, levou-me a compreender que a escola estudada, em seus últimos 10 anos de gestão, centra seus esforços na confecção de seu PPP, na composição de seu currículo, na gestão das relações humanas de forma a explorar a participação e o envolvimento geral de seus integrantes e na construção identitária da escola como pólo aglutinador das necessidades e interesses da comunidade.

Para dar conta do estudo sobre a escola que escolhi acompanhar neste estudo, considero necessário abordar a questão referente ao sentido e papel contemporâneo que a escola tem para seus integrantes, pois entendo que abordar os elementos que compõem a representação do que a escola é e do que deve ser, ajuda a melhor compreender como ela está alicerçada no ideário moderno e como a crítica a este ideário "abala" seus rumos.

Farei uso das observações de campo e, sobretudo, das conversas e entrevistas travadas com professores, alunos, agentes escolares, CPs e direção. O desafio será, portanto, analisar as idéias e ideais educacionais e pedagógicos que os diferentes agentes lançam mão quando falam do papel da escola, e confrontá-los seja com as impressões obtidas, seja com as condições estruturais e situacionais que a sociedade e o sistema de ensino lhes colocam.

Inicio assim com aqueles discursos carregados de todo o ideal moderno, preocupados assim, com a "formação completa do indivíduo". A supervisora escolar, embora diga que vá 
dizer algo que "todo mundo fala hoje em dia", não hesita em proferir que o papel da escola hoje é

formar o cidadão nos múltiplos sentidos. Aprender o convívio, o respeito, dialogar, trocar. Além disso, disponibilizar as ferramentas básicas para o aluno a aprender a aprender... Boas condições de leitura, escrita, e reflexão.

A auxiliar de direção vai na mesma linha ao dizer que é "a formação total do indivíduo: cognitivo, emocional, social". Isto revela, no mínimo, a "atualidade" do discurso e sua sintonia com as teorias pedagógicas de cunho construtivista, do "aprender a aprender" muito presentes na formação contínua de professores das mais diferentes formas.

Outro aspecto, bastante recorrente, principalmente na fala de pais e alunos é que o papel da escola tem a ver com aquela histórica idéia de "ser alguém" no futuro. "Preparar para o futuro", "ser alguém na vida" vêm associadas à idéia da aluna $\mathrm{C}$ de que "os professores preparam a gente para o vestibular". A agente escolar A é categórica: "pra mim a escola tinha que fazer com que o aluno soubesse ler e saísse encaminhado numa profissão! Que ele soubesse o que ele quer fazer da sua vida!”. Entretanto, o imaginário de que a escola vai garantir a inclusão e a ascensão social é posto em questão pela professora $\mathrm{B}$, o que conseqüentemente a preocupa a respeito de para que a escola deveria servir.

\footnotetext{
Quando a gente ia pra escola, pra aprender, a gente tinha perspectiva de ter uma vida melhor. Era através do emprego... era através do estudo que você tinha a ascensão social. Hoje em dia eles não têm muita perspectiva. Você ensina pra eles, mas não têm muita razão pra aprender, o que eles vão fazer com isso? O pai tá desempregado... E o meio que eles estão também não é fácil, meninos que você não imagina, estão na marginalidade, uns não querem nada com nada. $\mathrm{E}$ acho que a gente não está fazendo muito pra mudar isso...
}

Estas mudanças no mundo do trabalho, nas relações familiares, também são sentidas por professores no que tange a própria delimitação da relação professor-aluno. A professora $\mathrm{D}$ diz que

a população aumentou, a escola está aberta... As mães estão sendo mais duras com seus filhos, ela está trabalhando, ganhando dinheiro e os filhos estão 'atrapalhando' este dia-a-dia delas.

Tais considerações confrontam o ideal moderno de educação e escola com alguns questionamentos colocados pelo pensamento pós-moderno e pelas mudanças estruturais no mundo do trabalho na contemporaneidade. A representação de que a instituição moderna escola será capaz de permitir a ascensão intelectual, social e sobretudo profissional daqueles 
que passam por ela, preenchem o imaginário e a expectativa das famílias e alunos. Da mesma forma, colocam os professores e profissionais da escola diante da questão do que ensinar em um mundo no qual a função "tradicional" da escola já não corresponde, em muitos sentidos, ao que a sociedade demanda dela. Aqui me refiro ao fato de que a prática democrática deweyana e a segurança de obter um posto de trabalho já não se limitam à passagem e permanência pelos bancos escolares. Embora seja imprescindível, a "formação integral" do sujeito e a garantia de uma profissão ultrapassam as margens do universo escolar.

Relacionado a isto, outro elemento bastante comentado se refere a exercitar, tanto na escola como fora dela, a cidadania. Aqui engloba-se não só o aspecto democrático das relações sociais, mas também a compreensão dos direitos e deveres de cada integrante da comunidade escolar e sua efetiva participação no espaço público. Com relação ao primeiro ponto, o diretor afirma que, mesmo embora se caia, por vezes, ou em um "democratismo", um excesso de discussão e ausência de tomada de decisões, ou na fusão de interesses públicos com os interesses privados, a escola busca fazer com que as relações democráticas sejam em última instância para atender a comunidade.

\begin{abstract}
A maioria já entendeu que democrático é aquilo que atende melhor o grupo, para atender a função pública da escola, que é alfabetizar as crianças. A democracia tem que ser, em última instância, para atender ao aluno. A gente vota, debate, decide para melhorar nossa ação, nosso projeto. Abrir mão de si, para que o grupo se fortaleça, pra que a gente consiga atender melhor a comunidade.
\end{abstract}

Com relação ao segundo ponto, os direitos e deveres de cada um, alguns professores investem seu discurso na crença de que a escola deve proporcionar a capacidade de escolha aos alunos, enquanto que estes, percebem as forças disciplinarizadoras da escola/professores sobre suas ações e intenções.

Entendo que o papel e o sentido da escola se funda, sobretudo na questão do currículo escolar, em sua dicotomia entre trabalhar, transmitir os conhecimentos historicamente adquiridos e socializar, trabalhar a relação humana, o limite, a convivência grupal, o aprender a aprender, etc. É evidente que estes dois aspectos não se excluem, porém, também é sabido que atingir um ponto de equilíbrio entre estas duas dimensões, sociais e pedagógicas, passa pelo universo das representações, das tradições e da constituição histórica da própria cultura escolar.

Foi curioso ouvir os diferentes adultos, pois eles não convergiam com relação a esta questão. Se para uns, como por exemplo o assistente de direção, "o papel da escola é 
sociabilizar o aluno", estando o conhecimento em um segundo plano, para outros, como o próprio diretor, que paradoxalmente é um dos maiores protagonistas do "investimento nas relações", a escola tem que trabalhar o conhecimento. Segundo ele:

A escola tem uma função social. Não é pra fazer o que quiser. É pra trabalhar o conhecimento adquirido, a socialização dos conhecimentos... Tem muita escola que está fazendo o que quiser... Mas e o conhecimento? E a questão cartesiana? E a herança socialmente adquirida? A gente faz um monte de ações, mas com a compreensão de que nossa tarefa é alfabetizar este menino, para o letramento, para a ciência e para o conhecimento.

Nesta linha, a professora $\mathrm{B}$ considera importante que a escola deva possibilitar às pessoas "cresceram, terem suas escolhas, para sua melhoria de vida. Ter conhecimento [sobre] as artes, a história, (...) pois quem não conhece, não escolhe!"

Esta análise toca nas questões que envolvem as relações entre escola, família e sociedade. Qual o papel que cada um tem nesta dinâmica é algo claramente em mutação e sentido pela escola. Numa postura mais conservadora, as agentes escolares e alguns professores falam sobre o fato de que os alunos vêm para a escola atualmente sem regras básicas de convivência, conduta, higiene, etc., enquanto a direção/coordenação enxerga aí um dos próprios papéis da escola atualmente. Curioso perceber a relação entre a postura ideológica e o vínculo profissional que cada um destes profissionais tem com os alunos. Quanto mais próxima e direta a relação cotidiana com o aluno, maior a insatisfação, e quanto maior a distância, maior a "tranqüilidade" em assumir este papel social antes centrado na família.

Este movimento tenso, contraditório, muitas vezes velado nas falas e revelado nas práticas, aponta as dificuldades e desafios do que ensinar na escola de hoje. O que deve compor o currículo escolar? Sob quais objetivos e justificativas? Através de quais procedimentos?

$\mathrm{Na}$ fala da agente escolar $\mathrm{C}$, é possível identificar o conflito histórico entre os referenciais de ensino de décadas atrás com suas mutações pedagógicas contemporâneas. Conservadorismo e saudosismo se misturam à crítica ao excesso de práticas pedagógicas lúdicas e puramente recreativas.

Tem coisa que eles (professores) fazem que a gente não acha certa. Porque a gente é meio antiga!! Eles levam as crianças no parque, pra ver a árvore, contar as folhas... só que a gente não passou por isso, então a gente acha que eles estão descansando. Só que tem muito passeio que eu também vou e vejo que eu fico explicando mais que o próprio professor. Senta num canto e não se interessa. Não faz nenhum trabalho com os alunos na volta. A gente não vê depois na parede. Faz tempo que não vemos um trabalho sobre a pátria... (sobre) o índio... 
Esta questão é problematizada por Giroux (1995:73/4) que chama a atenção para que não se caia na euforia de tradições liberal-progressistas

nas quais o ensino se reduz a fazer com que os estudantes simplesmente expressem ou avaliem suas própria experiências...o ensino se encrava na noção banal de facilitação e a experiência dos estudantes se converte em veículo não problemático para a autofirmação e autoconsciência.

A escola e o diretor, principalmente, advogam em favor da utilização do lúdico como estratégia de aprendizagem para "trazer" o aluno para o mundo do conhecimento. A direção aponta o seguinte:

Tenho que buscar seduzir este menino para o desejo de se disciplinar ao conhecimento. Porque o conhecimento é algo chato, requer tempo, disciplina, consultar, ler, pesquisar... se este menino não é seduzido pra isso, se ninguém mostra o caminho, ele não vai.

Entretanto, a compreensão que se adquire da função do lúdico, de brincadeiras com fins pedagógicos, de jogos, revela os ruídos de comunicação e compreensão das idéias e teorias pedagógicas do "aprender a aprender", tanto na fala da professora A quando diz que "o professor não pode só cobrar, tem que ter diversão", quanto no depoimento da CP B:

...mas os professores têm dificuldade de visualizar isto. $\mathrm{O}$ diretor bate na tecla, diz pra eles descerem pra brincar com as crianças, depois registrar isso, ver o que aprendeu...mas a gente tem que estar sempre ali...porque não faz parte da prática. Ou então se perde. Acha que tem que descer toda semana e não amarra, não tem nada a ver, vira um laissez faire. O difícil é manter o equilíbrio. Isto é o principal, saber o que está fazendo e porque está fazendo.

Gostaria de encerrar esta parte do trabalho considerando alguns comentários a respeito das dificuldades que passam as escolas ao que se refere tanto às exigências da sociedade quanto ao que entendem ser papel obrigatório da própria escola e o porquê de sua não efetivação. Na entrevista com o grupo de agentes escolares, num determinado momento da conversa, uma delas (a) proferiu este dilema contemporâneo:

A educação é uma área muito complicada, a sociedade exige demais da escola. Num tempo pequeno, muito conteúdo tem que ser passado. Porque ele (o aluno) tem que se divertir, na escola, que se relacionar, tem que se educar na escola. Mas o tempo é muito pouco e é muita gente! 
Libâneo (1996:162) também crítica a assimetria na relação sociedade-escola, no que tange ao "projeto" iluminista e o enfrentamento dos profissionais da educação dentro do sistema capitalista.

...a modernidade iluminista talvez tenha pedido muito à escola, mas depois lavou as mãos, quando as elites sociais e econômicas abandonaram o ideário de educação pública e perderam o interesse pela operacionalização, obrigando os intelectuais a desmistificarem o universo do educativo nas condições sociais do capitalismo.

$\mathrm{Na}$ entrevista com o diretor, ele avalia a função pública da escola, sua relação com o poder público e aponta o maior desafio que lhe está colocado:

Porque a gente tem uma confusão histórica que dizia que antes a escola pública era boa, é ilusão, pois era uma escola estatal que atendia uma pequena parte da população. Hoje as massas estão chegando à escola. $\mathrm{O}$ que a gente precisa é construir um PPP para que esta escola pública atenda a comunidade como um todo... A maioria das escolas está atendendo as estatísticas do poder municipal, estadual, federal, do banco mundial. Fica um modismo. No conjunto as escolas não têm tido capacidade pra cumprir sua função. Por quê? Porque elas não têm construído seu PPP, ficam a reboque e a mercê do governo, aguardando a ordem de cima. O que ocorre? Todos ficam angustiados, impotentes, frustrados... e não conseguem ter um projeto. A educação só vai mudar quando cada escola tiver seu projeto!

Ao longo deste estudo de caso, procurou-se tecer as amarras que relacionassem as múltiplas dimensões da escola - o PPP, a gestão escolar, a relação com a comunidade e a aprendizagem - com as diferentes vozes que preenchem este cenário. Para tanto, se buscou compreender, analisar as práticas, as ações, as representações daquilo que afeta a vida daqueles que, seja por compromisso, por obrigação, por exigência social, por realização pessoal, etc., compõem o cotidiano de uma escola incrustada em um bairro pobre da cidade de São Paulo.

Em seguida, é momento de trazer à discussão, as questões que envolvem mais diretamente o campo teórico-prático do currículo, sobretudo, em sua concepção crítica e póscrítica/pós-estruturalista retomando assim a análise dos dados empíricos. Para além da metodologia do estudo de caso proposto neste capítulo, o que se procurará fazer em seguida é analisar como o currículo se coloca diante do pensamento, discurso e condição pós-moderno, e como a posição pós-estruturalista pode "ler" os fenômenos do currículo escolar. Isto porque, e de acordo com André (1992:40), os estudos de caso tem certo valor heurístico, isto é, oferecem certos insights e conhecimentos que clarificam os vários sentidos do fenômeno estudado, levando a descobrir novas significações, estabelecer novas relações, ampliando experiências. São estes conhecimentos que permitem levar a cabo o aprofundamento de determinadas 
proposições teóricas e de novos estudos. Entendo assim, que é a partir deste estudo de caso desta escola e seu currículo - que se poderá neste seguinte momento (o capítulo IV) cruzar tais insights com o debate posto pelo pensamento, discurso e condição pós-moderno. 


\section{Capítulo IV - Currículo e escola na encruzilhada pós-moderna}

Este longo percurso teórico sobre a crise da modernidade e a constituição de um pensamento crítico a ela, muitas vezes nomeado de pós-moderno, assim como sobre o ideário pedagógico moderno e sua constituição na educação brasileira, quando confrontados com os dados empíricos de uma escola pública paulistana concreta, viva - inserida no cotidiano de uma cidade, submetida às políticas públicas educacionais regionais e nacionais, influenciada por diversas tendências e correntes pedagógicas presentes na atualidade - leva a uma imensa abertura possível de campo de análise sobre como as escolas brasileiras têm respondido às proposições colocadas por este pensamento crítico à modernidade.

Entendo que, somente após a interpretação dos dados empíricos do estudo de caso seria possível, de fato, direcionar a reflexão, de forma mais específica para alguns dos elementos que o pensamento, o discurso e a condição pós-modernos constróem em sua crítica ao estatuto da modernidade, conforme se explicitou no capítulo I. Por conta disso, vale levantar tais questões para o encaminhamento deste trabalho: a partir do estudo de caso apresentado, quais elementos podem ser considerados como relevantes para o entendimento das práticas, ações e discursos da escola à luz do que a pós-modernidade coloca como debate à educação e as escolas na contemporaneidade? Existe um eixo central que articula as diferentes dimensões do trabalho escolar, os múltiplos sujeitos da dinâmica dessa instituição a partir do que foi apresentado neste estudo? Como o fio que tece práticas, discursos e ações dos diferentes agentes dialoga com proposições de âmbito filosófico mais amplo?

Por conta destas questões, compreendi que a categoria de currículo poderia, em grande medida, dar conta da articulação das múltiplas dimensões que foram trazidas para a reflexão no capítulo anterior, ao passo que, como campo teórico, o currículo tem mostrado um diálogo fértil com as problematizações postas pelo pensamento pós-moderno. Entende-se, assim, que o que foi visto, o que foi dito, o que foi escutado, o que foi silenciado, o que foi explicitado, o que se mostrou consensuado, e conflitante entre professores, alunos, direção, coordenação, agentes escolares e comunidade giram em torno do que a escola problematiza e constrói como sendo o seu próprio currículo. Para isso, recorro a uma definição "geral" de Moreira (1997:11) sobre o que é o currículo, entendido assim como campo de reflexão e ação pedagógicas, preocupado tanto com “os processos de conservação, transformação e renovação dos conhecimentos historicamente acumulados como para socializar as crianças e os jovens segundo valores tidos como desejáveis". 
Far-se-á necessário, antes, encontrar articulações políticas e epistemológicas entre o campo teórico do currículo e alguns dos questionamentos que o pensamento pós-moderno coloca ao estatuto da modernidade, procurando, por conseqüência, apontar para como as escolas - no caso por intermédio de nosso estudo - estão respondendo e lidando com estas problematizações. Nesse sentido, é central para este trabalho investigar como a escola se coloca, através de seu currículo, diante das proposições políticas e epistemológicas do pensamento pós-moderno, assim como diante dos condicionantes sociais contemporâneos .

Por conta disso, retomar-se-á centralmente a idéia levantada no início deste trabalho de que um dos enfrentamentos centrais colocado por este pensamento corresponde à crítica às metas narrativas da modernidade e à produção do conhecimento e sua validação epistemológica e da construção da identidade do sujeito contemporâneo.

\section{Currículo: situando epistemológica e politicamente o campo na contemporaneidade}

Antes de mergulhar propriamente na reflexão destas questões, vale uma incursão sobre o campo do currículo e de suas mudanças no âmbito histórico, epistemológico e político e de forma a analisar a presença de certos alicerces do pensamento pós-moderno (sobretudo a partir da teoria pós-crítica do currículo), com seus desdobramentos, avanços e limites.

Tomando por base os estudos de Moreira (1997) e Silva (1999a), este campo do conhecimento constitui-se historicamente, no início do século $\mathrm{XX}$, pela preocupação com o conteúdo que o aluno deveria aprender e pelos valores e experiências que a escola deveria desenvolver e proporcionar a esse aluno. Tem-se aqui, o que Silva (idem) chama de currículo tradicional, na qual se preserva a idéia de que o currículo é o conjunto de conhecimentos e experiências que o aluno deve assimilar ao longo da vida escolar.

O avanço dos estudos, sob a influência da psicologia comportamental, leva o currículo para o detalhamento de sua aplicação, explicitando seus planos, objetivos e finalidades, recaindo em uma formalização de seu conteúdo. Reside até aqui, no âmbito epistemológico, a visão de que o currículo é a transmissão de conhecimentos/valores tidos como desinteressados, neutros e científicos, por consequiência, fora do âmbito político. Não se questiona o que se conhece, o que permite deslocar a questão para o como ensinar aquilo que está sob "consenso" (Silva 1999a:16). Esta corrente de pensamento, segundo Silva (idem) surge nos EUA nos anos 20, com a finalidade central de favorecer o progresso nacional e a formação de mão-de-obra apta ao mundo do trabalho. O currículo se reduz assim à sua dimensão técnica e organizativa. 
Um seguinte passo, despontado, sobretudo, a partir dos anos 60 na Europa e nos anos 80 no Brasil, fruto do processo de redemocratização, procura colocar em questão exatamente este modelo-visão de teoria tradicional do currículo, efetuando uma inversão total de seus pressupostos. Se até então a teoria tradicional de currículo não questionava as formas dominantes de conhecimento e suas consequiências para a manutenção do status quo social e da dominação de uma classe social sobre a outra, dedicando-se simplesmente às formas de organização e elaboração do currículo, esta nova teoria - a chamada teoria crítica do currículo - surge exatamente para questionar os pressupostos epistemológicos de forma a revelar mecanismos ideológicos e materiais sustentadores das relações de dominação social que eram produzidos na escola (Silva 1999a). O currículo se torna, a partir de então, para além de sua dimensão epistemológica, um instrumento político produtor e reprodutor das desigualdades sociais. Está sob apurada investigação, não o que o currículo deveria fazer, mas sim os efeitos e consequiências do que ele $f a z$.

Nesse sentido, o caráter ideológico e reprodutivista do currículo escolar ganha luz nessas análises, pois se entende que a escola é, como afirma Althusser (1983), uma instituição do sistema capitalista e que tem como função reproduzir as relações de dominação deste sistema, se utilizando exatamente da ideologia como mecanismo de estratificação e permanência das desigualdades sociais. O currículo escolar é um instrumento ideológico que se produz e reforça as visões e interesses de classe, transportando idéias e valores da (e para a) classe dominante, excluindo assim dos subordinados a capacidade de inversão do sistema social (Silva 1999a).

Entretanto, a teoria crítica do currículo não ficaria restrita à análise marxista. Bourdieu e Passeron (1975), ao lançar mão da categoria de capital cultural, levam a compreender que a escola é uma instituição social que busca reproduzir as desigualdades e diferenças sociais porque o currículo é o instrumento que legitima a cultura do grupo dominante. Silva (1999a:35) afirma: "o currículo da escola está baseado na cultura dominante: ele se expressa na linguagem dominante, ele é transmitido através do código cultural dominante". Enquanto os membros deste grupo social entendem tais códigos, os do grupo dominado sofrem um processo de exclusão, por não compartilharem do mesmo capital cultural. O currículo escolar, assim, garante que um capital cultural cresça e avance, enquanto que o outro se estagne e seja excluído.

Estas duas colocações deram abertura para questionar o currículo para muito além do como ensinar. $O$ que ensinar e, sobretudo, por que ensinar isto e não aquilo se vislumbraram como perguntas centrais em torno da qual orbitaram as investigações do campo. Vale assim 
mencionar, a "revelação" trazida pelo chamado currículo oculto ${ }^{30}$, na qual se busca evidenciar as normas e valores subjacentes à transmissão dos conteúdos explicitamente assumidos, possibilitando enxergar através dos sutis caminhos institucionais da escola a manutenção de tais desigualdades.

A partir deste momento, já se tem a emersão da problemática do poder, imbricada na constituição das relações sociais e, neste caso, na noção de currículo. A teoria crítica rompe com a noção de neutralidade, não-intencionalidade na produção e manutenção das relações com o conhecimento. A escola e o currículo sofrem a crítica e o que antes era um conhecimento neutro, apolítico, torna-se o produtor da formação da consciência submissa e favorável ao sistema capitalista. Assume-se assim, o currículo como território político de hegemonia da ideologia capitalista (Silva 1999a, Moreira, 1998). Apesar disso, por mais que se aprofundem tais análises e melhor teçam-se os fios que conectam currículo e estrutura social, não despontam, segundo Moreira (1998:21), estudos com "a preocupação de oferecer sugestões que facilitem ao professorado a formulações de práticas alternativas."

Entretanto, é principalmente a partir dos estudos de Michel Foucault (2000), das colocações do pensamento pós-moderno e pós-estruturalista que a categoria de currículo não pôde mais ser desvencilhada das relações de poder em um sentido mais radical. O campo do currículo no Brasil, sobretudo a partir da década de 90, torna-se um território de práticas discursivas envolvidas pela relação poder/saber. Fazer a crítica a esta relação não é, como proporia a pedagogia marxista ou freiriana, almejar ou supor uma outra relação, livre e emancipada do saber em relação ao poder. Silva (1999a:120) sintetiza bem as proposições foucaultianas e seu embate com o marxismo:

Foucault concebe o poder não como algo que se possui, nem como algo
fixo, nem tampouco como partindo de um centro, mas como uma relação,
como móvel e fluido, como capilar e estando em toda parte. Ainda em
oposição ao marxismo, para Foucault, o saber não é o outro do poder, não é
externo ao poder. Em vez disso, poder e saber são mutuamente
dependentes. Não existe saber que não seja a expressão de uma vontade de
poder. Ao mesmo tempo, não existe poder que não se utilize do saber.

Emerge daí uma perspectiva teórica do currículo que segundo Silva (idem) vai demarcar o campo para além da teoria crítica: é a chamada teoria pós-crítica de currículo. Um primeiro ponto central leva a cabo o debate entre representação e cultura nos modos de construção do real. A

\footnotetext{
${ }^{30}$ Michel Apple assim define currículo oculto: “normas e valores que são implícitas porém efetivamente transmitidos pelas escolas e que habitualmente não são mencionados na apresentação feitas pelos professores dos fins ou objetivos”. Cf. Apple, Michel. Ideologia e currículo. São Paulo: Ed. Brasiliense, 1982, pág. 127.
} 
cultura é menos um suposto conhecimento "universal" compartilhado por uma sociedade, na qual a escola teria a função de "transmiti-lo", por meio do currículo para as futuras gerações, e mais as construções simbólicas que estão para além da temporalidade histórica do sujeito que, através das representações sociais, este constrói sua compreensão e inserção na realidade, na cultura. Para isso, a representação é entendida não como espelho, reflexo "verdadeiro" do real, mas ao contrário, como, nos dizeres de Costa (1998:41) "noções que se estabelecem discursivamente, instituindo significados de acordo com critérios de validade e legitimidade estabelecidos segundo relações de poder." Por conta disso, o poder da linguagem e a linguagem como poder não se dissociam e a construção da cultura é um espaço de luta entre grupos pela garantir do domínio da linguagem, de proferir certos discursos e não outros.

É nesse sentido que o currículo pós-crítico é concebido como território político de disputa pela construção de significados - a representação da realidade, constitutiva do que é a cultura - a partir de práticas discursivas na qual poder e saber não se separam, isto é, deve-se identificar quem fala, de onde fala, e com quais recursos da linguagem para compreender a efetivação de determinadas idéias, práticas e significados e não outros. Costa (1998:38) sintetiza bem a proposta:

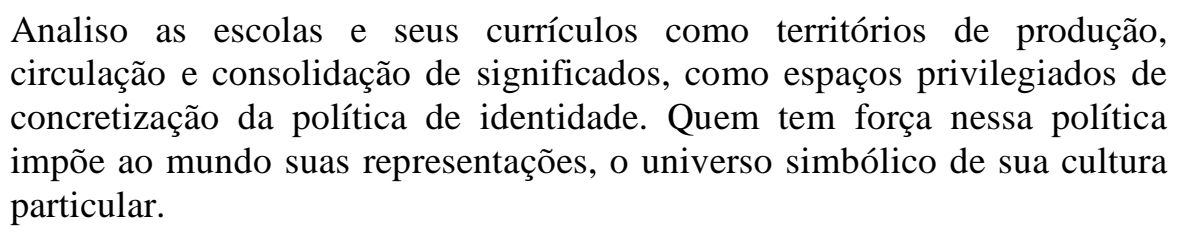

Isto revela, de certa forma, as bases epistemológicas e a concepção de sujeito residente na visão teórica pós-crítica. O sujeito centrado, autônomo, consciente, sofrendo os ataques do pensamento pós-moderno, é levado para o território da linguagem, do discurso, e o poder que ele exerce depende mais dos caminhos percorridos pela textualidade, pela microfísica (para utilizar um termo de Foucault) do que pela força da ideologia e das amarras da estrutura econômica ${ }^{31}$. O sujeito (pós) moderno é desterritorializado e envolvido pela rede do poder de forma infinita, instável, incerta. Ele não supera, transcende o poder e, à educação já não reside mais a "saída" para a libertação e emancipação. Não cabe mais buscar enxergar a realidade para além da ideologia e da dominação, pois a realidade é simplesmente fruto do lugar social e historicamente construído pelo sujeito e do discurso que ele profere. E é a própria

\footnotetext{
${ }^{31}$ Aqui não se pode perder de vista, e o próprio Silva (1999a) assinala, o perigo de se deslocar a crítica dos modos de dominação e exploração produzido pelas estruturas socioeconômicas - as grandes corporações industriais, financeiras e comercias, o Estado Nacional como representante de interesse classistas - tão bem formuladas pela análise marxista, para apenas os mecanismo capilares de poder e domínio nas micro relações sociais.
} 
transitoriedade e contingência dos territórios que o sujeito assume, a construção da identidade do sujeito.

Analisando os pressupostos criticados da teoria crítica pela teoria pós-crítica, Silva (1999a:115) afirma:

\begin{abstract}
A teorização crítica do currículo não existiria sem o pressuposto de um sujeito que, através de um currículo crítico, se tornaria, finalmente emancipado e libertado. O pós-modernismo desconfia profundamente dos impulsos emancipadores e libertadores da pedagogia crítica. Em última análise, está a mesma vontade de domínio e controle da epistemologia moderna.
\end{abstract}

Outro elemento importante que a teoria pós-crítica "acrescenta" corresponde a pensar as relações de dominação para além da luta de classes, na medida em que se consideram as relações de gênero, etnia, raça e sexualidade como também envolvidas pelo tecido do poder. Nesse sentido, o campo do currículo é visto como mais abrangente e capaz de reproduzir relações de domínio e assimetria através da visão trazida sobre a sexualidade, as diferenças etno-culturais, a noção de masculino/feminino, etc. Em termos políticos, não por acaso, vê-se a emergência dos novos movimentos sociais, de forma a lutar contra as formas de dominação para além (e aquém) da estrutura econômica e da luta de classes, como os movimentos sociais mobilizados por temas, como a sexualidade, as etnias, a ecologia, etc.

Outra questão central, de matriz epistemológica é fruto da chamada virada lingüística, mencionada capítulo I. O poder da linguagem e a linguagem como poder procuram aqui ocupar o território político da verdade, ao passo que dela retiram o caráter neutro e transparente de representação do mundo e da realidade. Há um deslocamento do poder de verdade estabelecido pela modernidade no sujeito - um sujeito cognoscente, auto-centrado, autônomo e racional - para um poder sediado na linguagem, em suas formas discursivas envolvidas pelas relações de poder. Portanto, é o poder do discurso e o discurso como poder o que sustenta e viabiliza a "luta pela verdade". Em termos práticos, aquele que melhor (im)por seu argumento tem maiores chances de definir a "representação" da realidade e, por conseqüência, em colocá-la em ação.

Isto leva, por conseqüência, à crítica da teoria do conhecimento. A ciência não é mais considerada como um conhecimento verdadeiro, pois a própria noção de verdade está em xeque, na medida em que está pactuada com o poder. A verdade se relativiza, e, em termos do currículo, os conhecimentos tidos como científicos têm agora que compartilhar e disputar espaço com outros conhecimentos tidos como não-científicos. O conhecimento e a cultura 
popular ganham espaço nesta perspectiva teórica, pois se entende, que se houver qualquer tipo de hierarquização do conhecimento, da cultura, é a evidenciação da manifestação de determinados dispositivos que almejam validar um conhecimento, uma determinada cultura e não outra. Nesse sentido, a pergunta que fica, e que é central para a teoria pós-crítica, é, pois: por que estes conhecimentos devem compor o currículo e não outros? E quais mecanismos são disponibilizados para que se garanta está escolha ao invés de outras possíveis?

Em síntese, no entendimento da tipologia de Silva (1993, 1999a) se a teoria crítica educacional buscava compreender para transformar a realidade, a crítica feita a esta teoria - a chamada teoria pós-crítica - procura compreender criticando os próprios modos e mecanismos de compreensão do real. Vale, entretanto, comentar o risco que se tem quando se trabalha com essas tipologias por assim mais engessarem determinadas idéias em rótulos teóricos que menos ajudam a entender os conceitos e mais forçam a territorialização dos mesmos. Nesse sentido, não se pode correr o risco ao investigar o campo do currículo, e "associar livremente" que a teoria crítica é fruto da manutenção do pensamento moderno e a teoria pós-crítica é fruto dessa ruptura e, portanto, adere diretamente ao pensamento pósmoderno.

\section{O currículo da escola na encruzilhada pós-moderna}

Entendo que uma escola é um local no qual diferentes culturas se entrecruzam, trocam idéias, produzem encontros, conflitos, legitimam práticas, ações e discursos, interagem entre diferentes gerações e funções e que isso ocorre, sobretudo, por meio e a partir da relação com o conhecimento.

Quero assim dizer que a escola investigada, através de suas múltiplas ações e entre seus distintos agentes, constitui um tecido social, seja contraditório e conflitivo, seja harmônico e consensual, que em certos aspectos e certos momentos leva em consideração algumas proposições e desdobramentos que o pensamento pós-moderno coloca para a teoria/prática de currículo escolar.

Cabe agora, retomar certos "insights" que emergiram do campo empírico e "cruzá-los" com o referencial teórico no qual se baseia este estudo. Vamos nos situar, portanto, na identificação de como a escola, através de seu currículo, tem respondido às idéias, práticas e discursos sociais e pedagógicos que são fruto dos desdobramentos do pensamento e da condição pós-modernos no campo curricular e educacional. Para isso, valer-se-á dos recursos teóricos situados entre a teoria pedagógica crítica e pós-crítica como referencial de análise. 
Isto significa utilizar a teoria para melhor entender os fenômenos sociais, pedagógicos que ocorrem na escola, sem necessariamente um posicionamento unilateralmente favorável ou contrário a tais teorias.

É fruto desse "posicionamento" político-metodológico o fato de que se entende, conforme procurou-se analisar no capítulo I, estar o pensamento pós-moderno sediado em um movediço território político que ora faz coro à lógica neoliberal do capitalismo atual, ora, se instrumentaliza para resistir às múltiplas formas de opressão de nossa sociedade. Sua ambigüidade, "desterritorialidade", e postura quase que de "camaleão" contemporâneo, dão margem para diversas e contraditórias apropriações de suas idéias e discursos pelas mais distintas instituições, como neste caso, a escola. Com isso se quer dizer que as idéias do pensamento pós-moderno podem e são apropriadas e assumidas socialmente de forma ambígua e contraditória; da mesma forma que possibilitam a ampliação de formas de resistência social (como quando trazem a questão de gênero, de etnia, de sexo), facilitam a adesão aos ideais neoliberais em educação (valorização da aprendizagem autônomaindividual, perda da importância do papel do professor, fragilidade do papel do Estado e massificação associada a desqualificação do ensino).

Por conta disso, tão importante quanto buscar se posicionar criticamente diante dessas questões, será fundamental compreender como elas são apropriadas, absorvidas e incorporadas pelo universo escolar no currículo. Por consequiência, ao entender ser função da escola formar sujeitos de modo que se garanta justiça, igualdade e liberdade entre seus componentes, a partir da compreensão do lugar que ocupam no social e na história, por vezes será necessário chamar atenção para os perigos e riscos que esse ideário desencadeia, enquanto que, por outras, dever-se-á considerar os avanços trazidos para a educação e para o currículo.

Conforme foi visto no estudo de caso, na relação entre as diferentes culturas dentro do universo escolar, que se cruzam, se sobrepõem, se sintonizam, se contradizem, se homogeneízam, se hegemonizam, pode-se agora tocar em alguns elementos da vida da escola que me parecem "sintonizados" com este debate filosófico que atravessa a contemporaneidade.

As seguintes perguntas podem, de forma geral e inicial, orientar esta discussão. Podese caracterizar, delimitar o que é o currículo desta escola? O que se aprende e o que se ensina em sua prática cotidiana? Como é possível, por consequiência, articular tais práticas, ações e discursos com o debate filosófico referente à crise da modernidade? Como tem sido pensado o 
currículo escolar por este pensamento crítico da modernidade, sobretudo sob o prisma da teoria pós-crítica/pós-estruturalista do currículo?

Para iniciar, retomo a interpretação dos dados do estudo de caso de forma a balizar as questões que virão em seguida. A análise partiu, lá no início, de que a escola havia passado por um processo de mudança radical de suas práticas pedagógicas e de sua inserção social na comunidade. Detectou-se, assim, ter havido uma ruptura institucional ocorrida nos últimos anos da década de 90 a partir da chegada e constituição da nova (a atual) equipe gestora (o que inclui basicamente o diretor e seu vice e as duas CPs). Assim, afirmou-se ter sido esse "o divisor de águas" da trajetória da escola.

Entendeu-se que tal ruptura - a implementação de outras ações, práticas e discursos pedagógicos e sociais - atravessou várias dimensões da vida da escola e que o que se viu e viveu ao longo desta investigação empírica é fruto essencialmente do trabalho que vem sendo realizado e consolidado ao longo destes dez anos. Dessa forma, procurou-se mostrar que o trabalho da escola buscou atingir um outro patamar de relacionamento humano.

Compreende-se que a escola investiu em uma nova relação com o espaço público, preservando instalações, ampliando e reconfigurando suas funções (como quando "troca" um espaço que era destinado ao estacionamento de carros por jardins, playground, horta e churrasqueira para a realização de festas e eventos da comunidade escolar). Quando a escola começa a fazer bailes e atividades nos fins de semana e abre seus portões para atividades culturais e esportivas, a representação do espaço público também sofre alterações significativas, sobretudo quando praticamente cessam ocorrências de depredação e se constata o crescimento do envolvimento da comunidade, de alunos e pais em tais atividades.

Outro esforço fundamental refere-se à mudança nas relações humanas do ponto de vista da participação coletiva na gestão da escola e implementação do PPP. Seja quando alunos formam um Grêmio ou participam de uma "assembléia" para decidir sobre eventos culturais, ou quando agentes escolares dizem ter acesso à direção e sentem-se também educadores; seja ainda quando na reunião pedagógica os professores participam e decidem votando o que e como serão feitas determinadas atividades e eventos ao longo do ano, ou quando se busca articular o conhecimento com o trabalho docente e outros recursos (como a atividade na sala de Informática) o que está em jogo é uma reconfiguração das relações políticas que permite que outras vozes participem dos processos de decisão do currículo da escola.

Foi trazido assim, a questão da formação como elo importante das ações da escola. Formação esta relacionada aos alunos e aos profissionais da educação. A 
participação/formação política, a preocupação com o trabalho coletivo defendido pelo PPP, o estabelecimento do contrato escola/aluno, a autonomia de determinadas ações (como a elaboração e organização de campeonatos), o investimento em experiências culturais (visitas a museus, ida ao teatro, cinema, etc.) e esportivas (as atividades oferecidas nos fins de semana, como Karatê, Capoeira, Judô, Basquete, Futebol etc.), mostram a ampliação da formação do individuo para além da sala de aula. Por outro lado, o que se viu em sala de aula mostra as dificuldades, os descompassos, os conflitos, as contradições do trabalho docente, de sua relação geral com o currículo em ação da escola e com a estrutura do ensino. Isolamento, resistência, adesão, divergências ideológicas acompanhavam o processo de construção identitário do professor e da própria escola.

A questão que envolve o conhecimento trabalhado na escola, e que se traduzia essencialmente na relação didática (professor-conhecimento-aluno), revelou inúmeras tensões entre o que se diz e o que se faz, o que se defende e o que se realiza (pregação de autonomia discente e ação heteronômica docente, como se viu naquela fala da professora de Geografia a espera da chegada da CP para começar a reunião de professores). Confluía e combinava a manutenção de práticas de ensino tidas como tradicionais, com práticas e discursos tidos como construtivistas. Viu-se também o embate entre cultura acadêmica e cultura cotidiana, o qual, em termos de conteúdos didáticos, se refletia na presença de temas como sexualidade, drogas, higiene pessoal, a história do bairro, o samba, a história de vida de cientistas, etc., ao mesmo tempo em que se ensinava os Grandes Lagos estadunidenses, as inúmeras regras gramáticas da Língua Portuguesa, a visão positivista de ciência - neutra, especialista e verdadeira.

Como fruto desse debate pedagógico que se debruça sobre a questão do currículo escolar, do que ensinar, observou-se uma profusão de discursos que ora pendiam para a importância dos conteúdos, ora para a oferta de "experiências" democráticas e do estabelecimento de regras, normas e valores. Em termos sintéticos, esta questão gira em torno da capacidade do currículo da escola integrar o trabalho com o lúdico, com os valores e normas socialmente democrático-participativo com a necessidade de transmissão dos conhecimentos historicamente fundamentais para entender os fenômenos culturais, políticos e econômicos de nossa sociedade contemporânea.

Por fim, viram-se as representações que os diferentes integrantes da escola têm através da implementação e realização de seu currículo - do próprio papel da instituição na contemporaneidade. Isto conduziu essencialmente para o debate do que é e/ou deve ser a formação do ser humano, e do que a escola faz e/ou deve fazer para atingir esta finalidade. 
Seja buscando formar um sujeito consciente e crítico, conhecedor dos processos e fenômenos sociais, seja um cidadão capaz de se inserir no mundo do trabalho e na vida democrática, os diferentes agentes daquele universo articularam de forma coerente e/ou contraditória seu discurso de acordo com o que entendiam ser a representação do papel da escola.

\subsection{O lema "aprender a aprender" no currículo escolar contemporâneo}

$\mathrm{Na}$ medida em que o objetivo central deste trabalho consiste em analisar as contribuições e limites que o pensamento pós-moderno trazem à teoria e prática do currículo escolar e como o currículo da escola tem respondido, lidado com estas proposições, dedico este momento para lançar luz sobre como o pensamento, o discurso e a condição pósmodernos podem e/ou afetam o currículo e a vida da escola.

Quando se põe luz sobre a questão ensino-aprendizagem, e por conseqüência, à relação professor-aluno-conhecimento presente na escola, vê-se emergirem práticas, ações e discursos da direção, coordenação e professores que transitavam entre a pedagogia tida como tradicional e a pedagogia de cunho construtivista. Chamou-me a atenção a existência, quase sempre, de uma posição valorativa da segunda em relação à primeira, o que significava uma preocupação em se adotar mais a linha pedagógica construtivista, de forma a "superar" a pedagogia tradicional. A professora F, em uma conversa que tive com os professores, afirmou: "o diretor nos diz que muitas vezes temos uma prática construtivista mesmo sem teorizá-la, sem ter posto ela no papel".

Isso me levou a buscar na análise de Newton Duarte ${ }^{32}$ (2001:29) suporte para entender que os ideais pedagógicos escolanovistas e seu revigoramento difundido pelo movimento construtivista no Brasil nas últimas duas décadas, sobretudo, através do lema "aprender a aprender", em muitos aspectos, se materializam em "modismos pedagógicos" e coadunam com certas aberturas do pensamento e proposições pós-modernos, aderindo, assim, acriticamente à lógica do neoliberalismo do capitalismo atual. Vejamos, então, um pouco mais de perto o que o autor marxista defende. Duarte (2001) afirma haver quatro posicionamentos valorativos do lema "aprender a aprender":

Primeiro que as aprendizagens, conhecimentos e experiências, que o indivíduo realiza por si mesmo, são mais desejáveis do que aqueles transmitidos por outros (no caso, essencialmente pelo professor). Daí se traduz que aprender sozinho é sinônimo de maior

\footnotetext{
32 Tomamos por base seu estudo intitulado Vigotski $e$ o "aprender a aprender": crítica às apropriações neoliberais e pós-modernas da teoria vigotskiana. $2^{\text {a }}$ ed. Campinas: Autores Associados, 2001.
} 
autonomia e que o papel do professor, para não cercear ou coagir o aluno, deve ser apenas de um facilitador da aprendizagem realizada pelo aluno.

O segundo posicionamento valorativo é o de que é mais importante ao aluno construir o método de aquisição, elaboração e construção do conhecimento do que aprender os conhecimentos descobertos e elaborados por outras pessoas. $\mathrm{O}$ "aprender a aprender" defende, assim, a visão de que o importante na escola é criar condições para os alunos pensarem sozinhos (de forma autônoma), e que em termos práticos corresponde mais a incitar a descobrir a "atitude cientifica", o método, do que propriamente o conteúdo do conhecimento científico. Nesse sentido, caberia a escola, através de seu currículo, instrumentalizar o aluno a escolher, subsidiá-lo, em termos de métodos e procedimentos, a eleger o que quer conhecer.

O terceiro posicionamento se trata, segundo Duarte (2001:40), “do princípio segundo o qual a atividade do aluno, para ser verdadeiramente educativa deve ser impulsionada e dirigida pelos interesses e necessidades da própria criança”. Além de buscar por si mesmo o conhecimento e construir assim, seu próprio método de conhecer, entende-se que o motor desse processo seja o interesse do aluno.

O quarto e último posicionamento valorativo do lema "aprender a aprender" é o que se considera carecer de maior atenção por conta de sua simetria com os ideais neoliberais. Segundo Duarte (2001:41) a educação deve preparar os indivíduos para o acelerado processo de mudança, o que leva a interpretar a escola como lugar dos indivíduos aprenderem cada vez melhor a se adaptarem à realidade em mutação. Além disso, aqueles que não se "adaptarem a este processo" viverão um eterno anacronismo, o que exigiria das escolas então, formar nos indivíduos, as competências para melhor se inserirem no mundo, mundo este, o do trabalho no sistema capitalista.

Duarte (idem) está defendendo a tese de que o lema "aprender a aprender" cunhado pela pedagogia escolanovista e levado a cabo pelo construtivismo, chega ao ideário pedagógico contemporâneo compactuado com a ideologia neoliberal/pós-moderna da classe dominante do capitalismo atual. Tal ideologia está presente nas escolas e no ideário pedagógico que embasa professores e coordenadores pedagógicos, diretores e supervisores de ensino, e como foi visto, mesmo que de forma sutil no estudo de caso, se materializa através da visão que valoriza no aluno o início e fim do processo de aprendizagem e por conseqüência, valoriza a capacidade adaptativa do indivíduo aprendente, pois tal lema dá muito mais ênfase aos métodos e procedimentos do conhecer do que aos conteúdos e saberes historicamente consolidados necessários para a transformação social. Vale assim trazer os dizeres de Duarte (2001:56): 
O lema do 'aprender a aprender' desempenha importante papel na adequação do discurso pedagógico contemporâneo às necessidades do processo de mundialização do capitalismo, pela sua interna vinculação à categoria de adaptação que ocupa lugar de destaque tanto no discurso político-econômico neoliberal como nas teorias epistemológicas, psicológicas e pedagógicas de cunho construtivista.

Como se vê, o autor trata com similaridade as categorias neoliberal e pós-moderno, pois entende serem elas parte da ideologia do capitalismo atual, atuando na educação e nas escolas por meio do lema "aprender a aprender". Isto seguramente se remete às proposições de Jameson $(1985,1996)$ quando afirmava que o pós-modernismo é a lógica cultural do capitalismo tardio. A crítica de Duarte (2001) ao pensamento pós-moderno se volta aos desdobramentos daquilo que foi considerado os estatutos da modernidade. Apoiando-se em Chaui $^{33}$, o autor afirma que para o pós-moderno a razão e sua universalidade estariam em crise, o que poria em xeque categorias centrais de análise e transformação da realidade, como universalidade, objetividade, finalidade, progresso, verdade, unidade. Categorias estas que são partes fundantes da teoria social e do projeto socialista marxista. Não por acaso, para o autor, o relativismo ético e epistêmico, a fragmentação do real, os micro poderes, o poder da linguagem não devem ser considerados as "saídas" para esta crise. Voltarei a essas questões mais adiante.

O construtivismo, para Duarte (2001), é uma visão psicopedagógica que não só absorve o ideário neoliberal/pós-moderno, como, por conseqüência, não manifesta nenhum enfrentamento, através da escola/ensino/currículo, da estrutura da sociedade capitalista. Isto porque, ele entende que esta linha pedagógica é relativista e naturalizante (adaptativa) em sua acepção de ensino-aprendizagem. Como não se definem os saberes objetivos que devem ser transmitidos, e sim, espera-se que isso parta do aluno, todo conhecimento é válido. Além disso, esta visão naturalizante reduz as relações ensino-aprendizagem à interações espontâneas, naturais, retirando assim, dos sujeitos da educação a confiança na possibilidade de transformação social, a partir de ações coletivas intencionais. Nessa linha, vale recuperar uma idéia trazida pela professora B quando disse que "quem não conhece, não escolhe", o que incorreria no risco de esvaziar o processo educativo, relativizando o que e por quem se conhece, e absolutizando o através do que se conhece.

\footnotetext{
${ }^{33}$ Cf. Chauí, Marilena. "Vocação política e vocação científica da universidade”. Educação brasileira, Brasília: MEC/CRUB, 15(31), 1993.
} 
As preocupações de Duarte (2001) com a ideologia neoliberal do capitalismo atual penetradas na escola, através do lema "aprender a aprender" também remetem, necessariamente, à relação entre o mundo do trabalho e o mundo da escola. Embora se saiba da importância histórica e pedagógica em dissociar o mundo do trabalho do mundo da escola, estabelecendo finalidades distintas, ignorar sua relação social é correr o risco de não ver o quanto um determina o outro, ou ainda, não enxergar aquilo que Silva (1999b:78) apontou como a criação de uma cultura capitalista que depende de um discurso pedagógico sustentador de um projeto hegemônico. Ou seja, a impregnação nos discursos institucionais de reformas curriculares para o desenvolvimento nos alunos de habilidades, tais como criatividade, autonomia, capacidade de lidar com a diferença e com conflitos, ter espírito de liderança, capacidade de se comunicar, etc., são as competências consideradas essenciais nas qualificações dos profissionais atuais (Silva 1999b e Santos 1999), reproduzidas pelos discursos empresariais gerenciais e pela mídia em geral, e absorvida pelas escolas.

No âmbito interno das escolas e dessa escola em particular, o que se viu foi a sutil incorporação desse discurso por múltiplos agentes e em distintas dimensões. O documento do PPP, ao defender proposições pedagógicas de cunho construtivista, como no caso da "estimulação da auto-descoberta e valorização do aluno" e de um ensino que estabeleça "relação com a realidade do aluno, partindo do que ele conhece, ampliando-a", mostra a valorização do currículo com um ensino que se move pela auto-realização discente e pelas suas próprias experiências.

O debate sobre o papel da escola e de como se deve constituir a relação professoraluno-conhecimento se insere no debate pedagógico "conteúdos x procedimentos". Embora nem sempre ocorra, especialmente, por conta da "resistência" de parte dos professores, o discurso predominante sobre o currículo da escola absorve em alguma medida, os ditames do lema "aprender a aprender". Entende-se assim, que em alguns momentos, este lema está inserido nos discursos e práticas de alguns profissionais da escola como, por exemplo, quando se trouxe a fala da professora E: “...então eu tenho que buscar atividades que eles consigam realizar ou sozinhos ou com o meu auxílio. O que eu preciso fazer é que eles consigam ler, escrever, calcular e colocar em isso em prática no dia a dia deles." Quando vi seu trabalho em sala de aula, ocorria uma sucessiva distribuição/realização/correção de atividades em folhas xerocadas feitas pelos alunos, na qual, cabia a ela, fundamentalmente facilitar o aluno a que ele fizesse a tarefa individual e autonomamente.

Quando direção e coordenação pedagógica defendem a importância do lúdico e das atividades esportivas oferecidas pela escola, embora se preocupem para que não se caia em 
um laissez faire, corre-se o risco de a atividade didática ficar restrita a um "procedimentalismo", presa ao conhecimento experiencial do aluno. O risco de recair nesse ponto perpassa a prática-discurso da professora A: o professor deve "estabelecer objetivos e cumprir procedimentos. Para mim, o aluno tem que aprender não só com o conhecimento final (os conteúdos), mas com os meios para aprender." Também está posta esta questão na fala do Assistente de Direção quando afirma: "se a gente conseguir fazer do aluno um ser pensante, social. Ele não vai ter muita informação, mas sabe pensar". Mas sobre o que ele pensaria sem ter a informação?

Esta visão de ensino chega ao aluno. Ao indagar o que era relevante aprender na escola o aluno E diz: "tudo é importante. Ter uma visão geral de tudo, e aí você vê o que você quer aprofundar. Aprender a escolher, ser criativo... aprendo a conviver em grupo." Nesta mesma linha está novamente a professora $\mathrm{A}$, ao fortalecer o discurso-prática que valoriza o papel da escola como espaço mais de sociabilidade do que de contato com o conhecimento: "o papel da escola não é só de aprendizagem e sim de socialização, desde (os anos) 70. O professor não pode só cobrar, tem que ter diversão."

A expressão do modismo se ratifica no discurso da supervisora escolar quando, questionada sobre qual a função da escola, afirma que vai dizer algo que todo mundo diz:

\footnotetext{
Vou falar uma coisa que todo mundo fala hoje. Que é formar o cidadão nos múltiplos sentidos. Aprender o convívio, o respeito, dialogar, trocar, então a questão da inserção real na vida democrática. (...) Além das ferramentas básicas para o aluno a aprender a aprender. Porque se o aluno consegue se relacionar bem, viver numa sociedade democrática e tem condições de aprender, a escola cumpriu então seu papel.
}

Como se afirmou anteriormente, o que se viu, com mais veemência, foi ou a sobreposição de um discurso construtivista em uma prática pedagógica tida como tradicional ou a implementação de um discurso/prática de cunho construtivista que incorria na secundarização da formação de conhecimentos socialmente relevantes. Entretanto, o que vale chamar a atenção é o quanto essas falas representam uma visão de ensino na qual o papel central do professor se fragiliza, dando lugar a um processo de mediação que deve começar e terminar no aluno. Como os alunos podem escolher, aprender a pensar e ser formado em sua completude, se estão postos em segundo plano os conteúdos, a informação e a veiculação do conhecimento produzido? Se a prioridade é aprender a se relacionar, aprender a conviver em grupo, a escolher, enfim, aprender a aprender, não se esvaziaria, ou ao menos fragilizaria a importância do que se ensina? 
Como isso não considero que o construtivismo não tenha proposições progressistas e positivas em relação ao ensino/aprendizagem. O que quero chamar a atenção é para a utilização e adequação de algumas destas proposições para uma educação de cunho neoliberal, na qual o peso e a força da instituição escola perde fôlego, na qual o professor e o conhecimento são deslocados para uma posição menos importantes e na qual o que mais se valoriza é a aprendizagem do e pelo aluno, a aprendizagem mais de procedimentos e habilidades em se relacionar socialmente do que de se apropriar de determinados conteúdos.

Retomando a questão de fundo que sustenta a análise marxista, o lema "aprender a aprender" deve ser entendido como um mecanismo ideológico sustentador da dominação de classe. Por outro lado, se fosse pensado sob a perspectiva pós-estruturalista, a partir do que vimos no item anterior, este lema se deslocaria, enquanto categoria de análise, para a idéia de discurso, um discurso sobre outros possíveis através de relações de poder-saber socialmente veiculados. Esta narrativa vai assim, se consolidando como discurso-prático e como prática discursiva na fala de inúmeros agentes educacionais/escolares, pois encontra respaldo social e pedagógico em algo que hoje parece situar-se em um território "consensual", que é, a valorização e a defesa do aluno. Isso ocorre, sobretudo, quando se procura encontrar as variáveis "responsáveis" pelos problemas da educação, como no caso do "fracasso escolar". Parece, assim, que a legitimidade dessa narrativa ao defender a aprendizagem ativa e autônoma do aluno, a necessidade de ele se adaptar às condições sociomateriais de vida, a aquisição de métodos de aprendizagem mais do que de conteúdos historicamente constituídos, vão ao encontro de uma "unanimidade" posta pela cultura acadêmica e pelos meios de comunicação que em grande medida "protege" o aluno, atribuindo responsabilidade aos pais e professores, à políticas educacionais do Estado.

Longe de querer com isso atribuir ao aluno a responsabilidade pelas mazelas do sistema público de ensino, e de que o aluno não deve ter autonomia na relação ensinoaprendizagem, o que se quer dizer é que a leitura pós-estruturalista ajuda a evidenciar a territorialidade de um sistema discursivo, que, se utilizando de determinados saberes-poderes, legitima-se como saber-fazer educacional influente que valoriza o processo individualizado de aprendizagem e enfraquece a escola como espaço coletivo de transformação. Seja como ideologia da classe dominante, seja como discurso predominante, o "aprender a aprender" desvaloriza, fragiliza o papel do professor e dos conteúdos como mediação necessária para o ensino-aprendizagem.

Talvez não por acaso, o Assistente de Direção vê com certa satisfação que não é necessário levar um professor para os passeios fora da escola. 


\subsection{O currículo entre a cidadania e o mundo do trabalho}

Outro aspecto central do currículo da escola corresponde à idéia de que o que se aprende e se ensina na escola remete ao mundo do trabalho, levando a escola a se deparar com os modos de inclusão/exclusão social postos pela condição pós-moderna. Aqui se situa uma dimensão mais sociológica, que correlaciona a preocupação interna do currículo e da estrutura de ensino com a formação dos indivíduos para o mundo do trabalho e para a vida social democrática.

Tais questões remetem ao debate contemporâneo no campo da teoria e prática políticas que é a da cidadania, isto é, o papel dos membros de uma comunidade em sua relação com os outros e com o Estado, em sua participação nos assuntos públicos, em seus direitos e deveres, etc.

As configurações contemporâneas que se impõem às sociedades modernas requerem de seus sujeitos, reflexão e ação no que tange à relação indivíduo-sociedade, sociedade civilEstado. Tais configurações - como a fragmentação do social, que agrupa indivíduos que assumem papéis sociais diversos; a aceleração na mudança dos costumes exigidos pela adaptação às novas tecnologias; a diminuição da delimitação das fronteiras geográficas e culturais dos povos, inclusive por conta do aumento da mobilidade social; a crise do Estado do Bem Estar social; a internacionalização do capital e o aumento do desemprego; a globalização econômica e a crescente desigualdade social; e o advento dos novos movimentos sociais - impõem de certa forma, uma redefinição da categoria de cidadania (Yáguez 2000). O que traz como demanda, ao menos, o questionamento, tanto do sentido geral da escola contemporânea quanto e de forma específica, do que deve compor o currículo de tais instituições.

Poderia assim traduzir nas seguintes perguntas o que se quer dizer: quais valores, conhecimentos e práticas sociais estão, e quais deveriam estar presentes na vida e no ambiente escolar? Neste sentido, conceitos como liberdade, igualdade, autonomia, participação, esfera pública e privada, indivíduo e comunidade orbitam o complexo cenário sociopolítico no qual as escolas estão inseridas. Mesmo se ignorar (ou não tomar consciência), qualquer escola brasileira, de alguma forma, está inserida neste debate, pois por ele perpassa a questão filosófica central em educação que é a de qual sujeito se pretende formar, quais valores se consideram válidos e quais conhecimentos necessários.

Sabe-se histórica e socialmente que nossa tradição ético-política provém em larga medida da perspectiva burguesa-liberal. Embora não seja possível aqui retomar seu percurso 
histórico, suas contradições e realizações, pode-se mesmo assim, apontar seus princípios básicos: a preservação das liberdades individuais (em oposição as normatizações da vida social, exercidas sobretudo pelo Estado), a existência de direitos naturais (que devem ser assegurados pelo Estado), portanto pré-existentes em relação ao processo de socialização, a realização do sujeito dentro esfera privada e a primazia da esfera econômica sobre a política (Yáguez 2000). Por conta da realização desses princípios no decurso histórico da modernidade, mesmo com suas contradições e enfrentamentos com outras correntes políticas - como o socialismo, o republicanismo, o anarquismo -, depara-se na atualidade, dentre outras coisas, com uma hegemonia da lógica neoliberal estatal - o Estado Mínimo -, uma privatização crescente do espaço e da esfera pública e uma atomização do sujeito social, atado, muitas vezes, a certo individualismo exacerbado. Santos (1999) chama a atenção para a proposição de uma cidadania que ultrapasse os moldes do modelo liberal - no qual a participação ocorre somente por meio do voto e da representação política. Caberia, portanto, uma teoria da emancipação que leve em conta as contribuições da cidadania liberal - Estado x cidadãos - mas que amplie sua dimensão para uma cidadania horizontal entre os indivíduos. Para além do campo estatal ou mercadológico, uma interação social na qual prevaleça a idéia de autonomia e solidariedade.

Santos (1999:263) assim formula sua proposta:

\begin{abstract}
A idéia da obrigatoriedade política horizontal entre cidadãos, e a idéia de participação e da solidariedade concretas na formulação da vontade geral são as únicas suscetíveis de fundar uma nova cultura política, em última estância, uma nova qualidade de vida pessoal e coletiva, assentada na autonomia e no autogoverno, na descentralização e na democracia participativa, no cooperativismo e na produção socialmente útil.
\end{abstract}

Como ficam, então, educação e escolas públicas da atualidade, sobretudo as brasileiras, diante desta "encruzilhada" pós-moderna, na qual, dentre outras coisas, ao passo que democratiza o acesso às massas historicamente excluídas do processo de escolarização (atingindo, assim, o próprio princípio liberal de direito à educação básica), produz novas formas de exclusão social, além do risco de fragilizar a escola como espaço públicocomunitário? Será que uma escola gestora de relações democráticas é capaz de por si engendrar uma sociedade democrática? É possível, ao nível microssocial das relações educativas escolares, da cultura escolar e de seu currículo, enfrentar estes mecanismos macrossociais contraditórios e excludentes, de forma a constituir de fato uma educação para a cidadania? 
A favor dessa possibilidade, Libâneo (1996:168/9) afirma que um dos papéis mais importantes da escola é a preparação para a participação social. "Um dos pontos fortes da pósmodernidade é a emergência de movimentos localizados, baseados em interesses comunitários mais restritos, no bairro, na região, nos pequenos grupos, organizados em associações civis, entidades não-governamentais, etc.” Nesse sentido a preparação para a participação social na e da escola seria requisito fundamental para constituir um controle e resistência pública não estatal sobre o próprio Estado e a sociedade civil. De acordo com o que se afirmou no capítulo I sobre os novos movimentos sociais buscarem estabelecer suas margens de atuação política sob bases distintas das de classe, partidos, etc., vê-se assim, a atuação desta escola pautada por esse tipo de inserção político-social, na qual se aproxima de movimentos sociais do bairro, de escolas de samba, de outras escolas públicas, de ONGs, etc.

Pode-se destacar a preocupação desta escola em formar seus indivíduos (e demarcar seu papel enquanto instituição social moderna) para e ao exercício da cidadania - entendida como tempo-espaço de realização do debate, negociação e acordo democrático que devem ser as ações e a finalidade da própria instituição. A chave central para a realização do trabalho da escola talvez esteja na fala da Auxiliar de direção: "independente dos projetos que fazemos, nada aqui é decidido por uma única pessoa”. O professor $\mathrm{F}$ caminhando na mesma direção afirma: "a gente percebe aqui uma gestão compartilhada, democrática, porque você é incluído, envolvido. Esta questão do aluno que se sente incluído, importante,(...) a não pichar, é porque ele passa a assumir este ambiente. Este ambiente também é dele."

A “assembléia" dos estudantes sobre o Caça Talentos ou na reunião de início de ano, na qual professores, coordenação e direção discutiam, debatiam, e deliberavam a respeito do trabalho do ano letivo, como por exemplo, os moldes da Feira Cultural, refletem, representam o exercício democrático de gestão, a participação ativa de vozes e atores que tradicionalmente não ocupam os espaços de decisão. A supervisora escolar diagnostica que um dos principais desafios de uma gestão mais democrática e participativa da escola brasileira reside no fato de que aqueles que estão no "comando", na liderança do trabalho - o que inclui direção, coordenação, professores, agentes escolares (e pais) - foram educados, socializados e construíram sua identidade pessoal, social e profissional sob a opressão da Ditadura Militar (1964-1985) enquanto que os atuais alunos já apareceram ao mundo sob o jugo da redemocratização.

Libâneo (idem:169/7) como recomendação a uma educação escolar pautada em princípios ético-comunicativos propõe: 
Investimento na capacidade do indivíduo em pensar-se em relação aos outros, de estabelecer relações entre objetos, pessoas, idéias; desenvolvimento da autonomia, isto é indivíduos capazes de reconhecer nas regras e normas o resultado do acordo mútuo, do respeito ao outro e da reciprocidade; formação de indivíduos capazes de ser interlocutores competentes: de expressar suas idéias, desejos e vontades, de forma cognitiva e verbal, incluindo a perspectiva do outro (...) e a capacidade de dialogar.

Tais elementos vão de acordo com os fenômenos observados de maior equalização nas relações de poder e de diálogo, como por exemplo, naquela fala da agente escolar B de que as relações sociais na escola haviam mudado muito desde 20 anos atrás.

Quanto ao relacionamento, antigamente era professores de um lado, funcionários, de outro, não tinha este entrosamento. Isso mudou com a entrada do diretor que disse que são todos iguais, todos educadores. Não tem esta separação. Desde a época que meu filho estudou aqui, cada um tinha o seu lugar... com a outra direção era difícil, era preciso muito esforço, pra gente conseguir falar com eles...

Caminha sob a mesma base quando se viu a autonomia e diálogo entre os alunos para organizar o torneio de futebol, estabelecendo a tabela dos jogos do torneio, trazendo árbitro (profissional), comprando troféus, etc., e na atuação e realizações do Grêmio da escola. Com relação ao Grêmio estudantil, inclusive, vê-se que a experiência que adquirem nesta escola vai se refletir na atuação no Ensino Médio. Segundo o Assistente de Direção ocorre o seguinte:

Pelo que sei saíram 4 alunos da $8^{\text {a }}$ serie que se tornaram presidente de Grêmio em outras escolas. A gente 'treina' aluno pra ser presidente de Grêmio em outras escolas, porque aqui ele ainda tem 13/14 anos, mas quando chega lá ele tem toda aquela bagagem...

Por outro lado, vale considerar que- sem para isso anular a relevância de tais formas de ações sociais cidadãs e inclusivas produzidas internamente pela escola - , a partir de Canário, Alves e Rolo (2001) contemporaneamente a escola pública brasileira - e a escola investigada não foge à regra - está (re)produzindo novas formas de exclusão social mesmo quando inclui escolarmente. Isto porque mesmo trilhando o percurso na instituição escolar não se assegura ao indivíduo o acesso ao mundo do trabalho e por conseqüência aos bens de consumo. Isto ocorreu em termos educacionais pelos resultados produzidos pela política educacional de Ciclos Básicos proposto pela rede de Ensino, tanto Municipal quanto Estadual de São Paulo na década de 90, que esteve muito mais preocupada em solucionar o 
estrangulamento do fluxo de alunos e de diminuir o ônus dos encargos públicos com um aluno que seria reprovado, do que em melhorar a qualidade de ensino.

Os efeitos pela forma como essa política tem sido implantada, garante maior permanência dos alunos na escolarização básica, sem, ao mesmo tempo, promover um ensino de qualidade que assegure o domínio das ferramentas básicas para seguir a vida escolar e universitária, por um lado, e do mundo profissional e dos bens de consumo, por outro.

A massificação da escola e a heterogeneização da clientela escolar trouxeram inúmeras mudanças para a configuração do trabalho do professor em sala de aula, para o significado e o conteúdo do currículo, assim como para o próprio sentido e finalidade da escola. Com a chegada de camadas mais pobres da população à escola pública, com necessidades, hábitos e (faltas de) infra-estrutura social, o que temos visto é um grande aumento das dificuldades postas ao professorado. Como mostrado no estudo de caso, (e não são poucos os estudos que têm trazido essas problemáticas), professores se queixam de alunos em idade-série avançada sem domínio de leitura, escrita e raciocínio lógico essenciais para a compreensão e inserção no mundo contemporâneo. Professores e auxiliares, sentindo os efeitos dessa condição social e educacional, se queixam da sensação de estar apenas cuidando dos alunos. Assim diz a professora A: “ às vezes parece que a gente só está aqui cuidando do filhos para os pais."

Outro problema mencionado corresponde ao desafio que a heterogeneidade, tanto de aprendizagem e domínio de certas ferramentas e conhecimentos, como cultural, a formação que os alunos recebem fora da escola, colocam à prática docente diária.

Aquilo que se afirmou sobre a fragilização do ensino e do papel do professor através do lema "aprender a aprender" talvez aqui encontre certo "encaixe" com a lógica produtivista neoliberal. Em vez de garantir o domínio de conteúdos e ferramentas básicas na e para a vida escolar, universitária e cidadã dos alunos, tal lema contribui para, ao acelerar a passagem da população pelos bancos escolares, colocar o professor como mediador da relação ensinoaprendizagem e relegar aos alunos, autonomamente, no futuro, a capacidade de aprender a ler, pensar, calcular, interpretar, criticar, etc., quando o mundo do trabalho requisitar.

Esta encruzilhada social é bem retratada na leitura feita pela CP A, quando analisa a ampliação das temáticas a serem abordadas pela escola e a necessidade de garantir a especificidade da escola, que entendo ser lidar, sobretudo, com o conhecimento sistematizado, através do desenvolvimento das ferramentas básicas de leitura e escrita do mundo social. 
Ela (a escola) tem assim, além da questão da socialização, mais importante é passar o conhecimento que vem sendo acumulado. Agora, é importante do papel da escola, ensinar a ler, escrever. Vejo também que a escola hoje em dia não pode ser algo fora do que acontece lá fora, fechada nos seus 4 muros, distante da realidade. Ela tem que estar se adaptando ao que acontece no mundo, trazer para dentro da escola. O que ocorre no momento é que todos os projetos entram na escola.... todos os temas entram na escola...A escola tem que trabalhar estes temas, porque são importantes, mas sem esquecer de qual é o seu papel. Porque senão os alunos passam aqui os 8 anos, estão super socializados, discutiram temas importantes, mas se você der um texto ele não consegue ler. Se não for feito aqui na escola, não tem outra instituição que faça isso. Esse negócio de internet, a família, eles não fazem isso. É aqui dentro da escola que se trabalham alguns conteúdos que só existem aqui. A escola tem que estar com um olhar fora, mas sem esquecer isso daí.

Estamos, assim, diante de um fenômeno histórico-educacional da escola pública brasileira que tem incluído a massa da população em idade escolar à instituição, criando formas de exclusão social, que marginalizam tais camadas sociais no acesso ao conhecimento historicamente consolidado e por conseqüência, futuramente, no mundo do trabalho e dos bens de consumo, ao mesmo tempo em que torna os diplomas escolares mais imprescindíveis e menos rentáveis (Canário, Alves e Rolo 2001).

Sem dúvida, creio que a experiência democrática, a autonomia de organização dos alunos, as inúmeras atividades esportivas, a participação em um grêmio estudantil, as atividades culturais e passeios realizados fora da escola, se cristalizarão na formação dos alunos que passam por essa escola. Muitas vezes escutei de alunos, de coordenação e de direção, relatos de que os alunos sentiam muita falta do ambiente da escola quando saiam para o Ensino Médio. Uma vez a CP B disse que alguns alunos da $8^{\mathrm{a}}$ série fizeram um abaixoassinado para "abrir" Ensino Médio na escola. A formação cultural também é detectada pelos alunos. O aluno B, C e E em entrevista afirmaram:

B - agora tem mais passeios.

C - como a escola é bem falada, são eles que vem oferecer passeios para a escola.

E - tem muito passeio e muito trabalho cultural.

A professora $\mathrm{F}$ ratifica está preocupação com a formação cultural quando comenta $\mathrm{o}$ trabalho de outra docente:

Estes alunos aí que a professora está falando são alunos que têm o hábito de ir ao teatro, no Municipal, em museus.... na verdade, se você pegar esse nosso aluno, mesmo de 1 a $4^{\mathrm{a}}$ serie, ele tem esse habito já de visitar esses lugares. Quando ele chega na $8^{\mathrm{a}}$ série, ele não foi só num passeio...ele já foi preparado pra ir nesses lugares. 
Embora, se entenda terem eles, uma formação mais ampla, mais abrangente, tocando sobretudo a dimensão cultural e política do ser humano, as marcas da debilidade do sistema de ensino atual delineadas pela lógica neoliberal do estado Mínimo, da maximização dos resultados com o mínimo de recursos financeiros, e os ditames pedagógicos do "aprender a aprender" (valorização da autonomia do aluno e valorização de técnicas e métodos ao invés de conhecimentos historicamente consolidados), confrontam a realidade e o futuro desses indivíduos.

Uma outra dimensão da relação inclusão/exclusão social pela da escola remete diretamente à questão do currículo. Costa (1998:56) ao analisar o currículo como política cultural $^{34}$, faz a crítica à pedagogia crítico-social dos conteúdos, que defende que mesmo com uma desigualdade social no ponto de partida da educação escolar - os empecilhos ao direito ao acesso à educação - a equidade se daria no ponto de chegada - ao fim da escolarização -, "pois a escola supriria qualquer defasagem, ensinando a todos e todas, crítica e indistintamente, o conhecimento universal, patrimônio cultural da humanidade". Para a autora, é necessário, mais que garantir o acesso às camadas historicamente excluídas da escolarização, promover um currículo escolar que além de evidenciar as formas de dominação de classe, etnia, sexo, idade, origem cultural, geográfica, produza formas de interlocução capazes de dar voz a sujeitos e narrativas até então excluídos e silenciados do processo de constituição de suas identidades.

\subsection{A perspectiva pós-estruturalista e o currículo como política cultural}

Aqui chego a uma dimensão do pós-moderno que parece ter fôlego teórico-conceitual para criticar determinadas forma de dominação na relação escola-sociedade. Aqui o pósmoderno é crítico, ou naqueles dizeres de Silva (1999a), pós-crítico e deve servir, não para aderir-se ao ideário neoliberal e às formas de exclusão social, mas, ao contrário, para estabelecer leituras do real capazes de evidenciar e desconstruir formas de dominação e desigualdade que perpassam a cultura e o currículo escolar.

Costa (1998) permite adentrar mais profundamente este debate sobre as teorias póscríticas/pós-estruturalista do currículo e seu desdobramento em um currículo como política cultural. Estar-se-á assim procurando, além de refletir sobre suas bases teórico-

\footnotetext{
${ }^{34}$ Trataremos deste ponto em seguida.
} 
epistemológicas, analisar os "moldes" de uma leitura pós-estruturalista do currículo da escola, apontando suas contribuições e limitações desse tipo de abordagem.

A partir dos apontamentos de Silva (1999a) a respeito das teorias pós-críticas/pósestruturalista do currículo pode-se compreender que a visão de currículo escolar para Costa (1998) está muito além do conjunto de conteúdos, disciplinas, métodos, experiências, objetivos, etc., que compõem a atividade escolar. Para a autora (1998:41),

o currículo e seus componentes constituem em conjunto articulado e normatizado de saberes, regidos por uma determinada ordem, estabelecida em uma arena em que estão em luta visões de mundo e onde se produzem, elegem e transmitem representações, narrativas, significados sobre coisas e seres do mundo.

Nesta perspectiva reside centralmente a questão foucaultiana (Foucault 2000) sobre o poder. Este é concebido essencialmente como capilar, circulante, disseminado e produtivo. Para Foucault (2000) o poder não é algo que se adquire, tal como uma propriedade, mas algo que não tem fim, que se constitui dinamicamente através de um jogo no qual o caminho a percorrer é pela estratégia e, seus efeitos de dominação, por técnicas, mecanismos, táticas capazes não de assegurá-lo, adquiri-lo definitivamente, mas de mantê-lo sempre numa tensão, em atividade permanente. Como diz o próprio filósofo (2000:29), o poder "se exerce mais do que se possui". Daí então que se pode pensá-lo como uma teia que perpassa, medeia todos os indivíduos, todo o corpo social, suas instituições e o Estado e movimenta e dá sentido à própria dinâmica social como um todo. O poder não está, portanto, retido nas mãos do Estado, ao contrário, é a ele que o Estado e as instituições sociais recorrem, se utilizam.

Por conta disso, pode-se entender que a noção de poder sustentado pelo pósestruturalismo de linha foucaultiana, consiste em seu caráter ao mesmo tempo disciplinador e produtivo (Foucault, 2000). A distinção na noção de poder que Silva (1995:252) faz da corrente marxista para a pós-estruturalista se resume no seguinte: "enquanto para a teorização crítica de inspiração marxista, por exemplo, o poder distorce, reprime, mistifica, para a perspectiva pós-estruturalista, o poder constitui, produz, cria identidade e subjetividades". Através de uma mecânica de poder, é possível engendrar mecanismos sutis e técnicas específicas nas quais o indivíduo moderno se descobriu como objeto e como sujeito do saber, tanto como sujeito a, como sujeito de. O poder, imerso nas instituições modernas, como a escola, procurou produzir e submeter o sujeito a certas formas de subjetivação, que mais que regulá-los, procura a auto-regulação, mais que governá-los, busca o auto-governo. 
A base dessa tecnologia política consiste na disciplinarização de corpos e mentes. Isto é o que Foucault (2000:126) chama de "métodos que permitem o controle minucioso das operações do corpo, que realizam a sujeição constante de suas forças e lhes impõem uma relação de docilidade-utilidade". Dividir, organizar e sistematizar o espaço e o tempo, de forma a extrair do corpo maior produtividade em suas ações e realizações, tornando o que era disperso e desorganizado, compacto e eficiente.

Isto permite entender que alunos, professores, agentes escolares, direção e coordenação estão inseridos em relações humanas nas qual o tecido do poder envolve a todos de forma a extrair deles produtividade e eficiência. Para isso se organiza o tempo e o espaço escolar de uma forma específica (ao invés de outras) - aulas de determinado tempo e em determinado lugar, lugares e tempos de lazer, divisão do conhecimento, disposição de carteiras nas salas de aulas, distribuição das salas dentro do edifício (salas dos professores, da direção, coordenação e administrativa de um lado, e salas de aula de outro), horário de entrada e de saída, filas para distribuir a merenda, momento de apresentação para a família dos trabalhos dos alunos realizados junto aos professores.

O poder vai além. Costa (1998) entende que o campo teórico e prático de constituição do currículo escolar é uma política da cultura, pois é um território no qual distintos sujeitos, discursos e práticas lutam para exercer e validar sua visão de mundo, de homem e de educação, ao invés de outras. O currículo escolar é, assim, um lugar privilegiado da instituição-escola para dirigir, governar corpos e mentes ao mesmo tempo em que estabelece as próprias formas de subjetivação. No currículo escolar o sujeito se forma e é formado, se governa e é governado, se disciplina e é disciplinado, produz e é produzido enquanto identidade cultural.

Entender o currículo como política cultural significa situá-lo em territórios que podem ser socialmente contestados, na medida em que se entende que ele tem se concretizado pela hegemonização de um sujeito histórico específico - geralmente masculino, branco, adulto, europeu, heterossexual, colonizador, etc. Criticar a disseminação deste modo de construção da realidade, ou do que McLaren e Giroux (2004) chamam de política de representação - disputa e "direito" de narrar o "outro" (Costa 1998) -, significa desestabilizar o exercício desse poder evidenciando seus mecanismos e tecnologias que o garantem e o reproduzem historicamente, de forma a viabilizar a constituição de outros saberes e poderes, outras narrativas e práticas, antes silenciadas, subjugadas e/ou marginalizadas. Esta perspectiva tem como objetivo concreto desconstruir os pilares que sustentam as relações de poder vigentes e em seu lugar, (re)territorializar outras vozes, de outros sujeitos - da mulher, do negro, do índio, do pobre, da 
criança, etc. - para que elaborem narrativas e construam identidades a partir de suas histórias de vida, de suas experiências sociais e do lugar que ocupam na escola e na sociedade.

Em termos do estudo de caso, pode-se fazer algumas considerações, que de alguma forma dialogam com estas proposições teóricas. Com isso não se quer dizer que o currículo da escola esteja assumindo uma perspectiva teórica pós-estruturalista, mas sim que as práticas, ações e discursos que ele produz levam em alguns aspectos, ao enfrentamento de algumas formas históricas de marginalização e submissão de uns por outros.

Sob esta perspectiva entende-se algumas mobilizações da escola para (re)constituir a identidade de seus integrantes sob outros referenciais. Penso assim, quando a agente escolar B que está na escola há 20 anos afirma que antes (de iniciar esta gestão) era "lei nazista", "preto de um lado, branco do outro" e que "atualmente todos sentam na mesma mesa, todos se sentem educadores da escola". Este mesmo movimento também pôde ser sentido no lugar geral que ocupam os alunos da escola. Participantes das atividades da escola e do bairro, seja o desfile em comemoração ao aniversário do bairro, sejam as atividades esportivas e culturais nos fins de semana; organizados em Grêmio Estudantil, definindo diretrizes de eventos por meio de assembléia, a voz e a presença dos alunos são nitidamente mais ativas, melhor situadas no mundo que os rodeia. A aluna D conta da participação dos alunos na simulação de um pleito eleitoral na escola:

Ano passado, antes das eleições, tivemos 'eleições' com os candidatos à Prefeitura pelo computador. Então era só chegar e votar pelo computador da escola... A escola fez isso pra abrir um pouco nossa mente, pra saber o que a gente pensa sobre o Brasil. Todo mundo se sentiu útil, por participar daquilo. Tem que ter muito diálogo. Aqui a gente aprende o que é o mundo, o Brasil.

A voz dos alunos também esteve na percepção daquele aluno ao compreender que o papel da escola é formar um "aluno manso", que não contesta. Embora aqui, seja uma questão contraditória, pois ao mesmo tempo o aluno sente os dispositivos disciplinares construindo sua própria subjetividade, e é capaz de situar-se fora deste modo de subjetivação.

Outro aspecto que pode ser considerado relevante diante da perspectiva pósestruturalista e da análise do currículo como política cultural corresponde às relações de poder inseridas nos papéis sociais/profissionais com a questão de gênero. A ocupação dos cargos na estrutura hierárquica da escola reflete, em grande medida, as diferenças sociais de gênero presentes no campo profissional da educação, assim como de outras áreas profissionais. Em termos concretos, o que se vê é o grupo de professores do Ensino Fundamental I ( $1^{\mathrm{a}}$ à $4^{\mathrm{a}}$ série $)$ composto basicamente por mulheres. Somente no Ensino Fundamental II ( $5^{\mathrm{a}}$ à $8^{\mathrm{a}}$ série) começa 
a surgir uma mescla, com a presença de parte do corpo docente de professores homens. Tornase mais curioso quando se observam os cargos de agente escolar, de coordenação pedagógica, auxiliar de direção, assistente de direção e direção, e se constata uma demarcação social de territórios, ocupados pelo "universo masculino" e pelo "universo feminino". Os três primeiros cargos são ocupados por mulheres, enquanto os dois últimos, por homens.

A análise do currículo escolar, sob esta perspectiva, procura explicitar que as relações de gênero, do espaço do homem e da mulher nos cargos da escola não ocorrem ausentes do exercício do poder. Busca-se a partir dessa análise desconstruir a representação que se constitui desses dois universos, possibilitando, assim, desnaturalizar aquilo que já parece casual, ou seja, o fato de que os trabalhos mais próximos do universo infantil e doméstico são feitos pelas mulheres, como o caso das professores de EFI, das agentes escolares (limpeza da escola) e das merendeiras (fazer a comida, nutrir as pessoas). Por outro lado, o trabalho de dirigir, de enxergar a "totalidade" do processo, de pensar abstratamente sobre o significado da educação e do ensino, fica a cargo dos homens, os quais têm para isso, duas profissionais - as coordenadoras pedagógicas - encarregadas de coordenar, concretizar, executar tais proposições seja da Coordenadoria de Ensino, seja da direção da escola.

Isso vai ao encontro da seguinte afirmação de Costa (1998:60):

O campo profissional do magistério de primeiro e segundo grau, maciçamente povoado por mulheres, tem sido pródigo na fabricação de representações que enquadram as professoras em certa 'ordem do coração', oposta à 'ordem da razão', tem contribuído para fortalecer as associações entre gênero feminino e déficits de raciocínio.

Em termos de formação dos indivíduos, vê-se que o currículo dessa escola é sensível ao impacto dos Estudos Culturais, na medida em que abre espaço para a interlocução de práticas, histórias e ações da cultura local. Como foi afirmado, a escola está incrustada numa região onde o samba (e as escolas de samba) faz parte do próprio processo de constituição da identidade cultural do bairro e da comunidade. Atento a isto, e mobilizado centralmente pela direção da escola, constata-se que o currículo, através de resistências e conflitos dos diferentes agentes, não ignora as manifestações culturais do bairro/comunidade quando traz para dentro de seu universo pedagógico, aulas de cavaquinho dadas por professores e pais da comunidade, quando alunos são convidados para apresentações em eventos da escola como o Pagode de Mesa, quando os integrantes da escola participam do desfile de rua de comemoração de 69 anos do bairro, quando o EFI traz o tema do samba para a sala de aula. Entende-se, dessa forma, que essas são manifestações de aproximação e intersecção da cultura acadêmica com a 
cultura popular, entre um currículo propedêutico e um currículo sensível ao universo cultural concreto daqueles que fazem parte da história de vida daquele bairro/comunidade.

Pode-se observar também, embora não tenha sido citado no capítulo anterior, algo que possa parecer irrelevante, mas que do ponto de vista do currículo como política cultural faz diferença. Quando visitei a Feira Cultural da escola, com as apresentações dos trabalhos desenvolvidos ao longo do ano entre professor e alunos, havia uma sala de Ciências com o desenho de corpo humano com os diferentes órgãos e sistemas (digestivo, respiratório, reprodutor, etc.). Entretanto, ao invés da "tradicional" representação do homem branco, havia 3 desenhos, representando o branco, o negro e o indígena. Estas são formas sutis de manifestação do que McLaren (1993) chama de uma política emancipatória da diferença, que valoriza o entendimento de que o conhecimento está imerso e é produto de relações de classe, raça e gênero, e que a escola deve procurar criar mecanismos de manifestação das diferentes culturas que a compõem.

Embora não tenha sido mobilizado a investigar o currículo como política cultural enquanto estive no trabalho de campo, procurei aqui destacar como as proposições teóricas de cunho pós-estruturalista podem "ler" certos fenômenos da escola e de seu currículo. Entretanto, e até por coerência a essa perspectiva, cabe considerar o movimento analítico desconstrucionista da perspectiva quando posta diante da concretização de um currículo escolar.

Nesse sentido, quando se iluminam as relações entre professores-alunos, direçãoagentes escolares, coordenação-professores, etc., esta perspectiva teórica, indissociando poder e saber, procura evidenciar os "regimes de verdade" que os constituem, ou seja, a disputa pela territorialização de poderes-saberes através de estratégias e mecanismos que procuram tornar hegemônicos certos discursos em determinados "lugares" e não outros.

A imersão na vida da escola, no contato com os diferentes integrantes, com as diferentes práticas e discursos sobre o que é educar, o que é e para que finalidade se deve formar o indivíduo, sob quais métodos e recursos pedagógicos pautados pela questão do poder-saber, leva a territorialização do discurso predominante para o "terreno" defendido pela direção da escola. O discurso e a prática que a direção dissemina por toda a escola, atinge agentes escolares, coordenação pedagógica e parte do corpo docente, de forma que mesmo havendo práticas, ações e discursos dissonantes, de qualquer forma, estes se estabelecem em mediação, em interlocução, e até em resistência a este que se hegemoniza.

Em termos concretos, a visão de aprendizagem na qual o aluno é mais ativo, participativo; na qual se dá mais atenção à discussão de regras e valores; na qual se abre mais 
espaço para atividades lúdicas; na qual o professor é mais um mediador do que transmissor do conhecimento; na qual se defende o aprender a aprender, predomina no discurso pedagógico, percorrem a prática do currículo da escola. Mesmo embora, muitas vezes, ocorra em sala de aula um ensino tradicional, como ao identificar o local e decorar os nomes dos Grandes Lagos dos EUA. A fala do diretor explicita bem estas contradições:

Claro que nós temos pessoas que são da pedagogia dos conteúdos, linha francesa, livro, do letramento... que não concorda com o lúdico, o afetivo e que a função da escola deve ser só ler e escrever. Tem gente que acha que fazer brincadeira, trabalhar com a escola de samba é uma bobagem. Mas a maioria consegue perceber que isto é importante, é uma ferramenta, e que nós somos uma escola diferenciada.

O que se quer dizer é que o que se materializa enquanto ação pedagógica é fruto da disputa por territorializar um determinado discurso e prática do currículo entre outros possíveis. Entendo que o pós-estruturalismo contribui ao evidenciar que o que se diz/defende é, para além de uma proposta/visão de educação, uma demarcação discursiva de relações de poder por meio de certos saberes. O discurso que se hegemoniza, que se instala como "satélite" para as relações humanas dentro e fora da escola, para a realização da ação docente, para o uso e significado do espaço escolar, etc., é aquele que vem de cima, da direção, sintonizada pela coordenação, das agentes escolares e parte dos professores e que encontra respaldo em uma "teoria social" que se sustenta na visão da escola como pólo aglutinador de ação política da comunidade, do ensino pautado pela concepção construtivista do "aprender a aprender", da aproximação com a comunidade, da parceria com entidades do bairro e ONGs, da abertura da escola aos fins de semana e da oferta de atividades esportivas e culturais, de maior abertura à participação de personagens escolares até então silenciados, marginalizados, excluídos dos processos de decisão. É nesse sentido, que Costa (1998:38) afirma que "quem tem força nesta política impõe ao mundo suas representações, o universo simbólico de sua cultura particular".

Não por acaso é a CP A que diz o seguinte:

Neste período, com o diretor trazendo essas mudanças em termos da relação com a comunidade, essa abertura mesmo para o que é do bairro, temas ligados ao carnaval, abrindo a escola aos fins de semana...acho que mudou a visão da escola. Mas eu não sinto que isso tenha uma mudança em sala de aula, com o professor. É uma mudança na escola, da visão da comunidade em relação a escola...mas lá na sala de aula, isso não muda. 
A compreensão do "real" - produto destas práticas discursivas preenchidas pela relação poder-saber - também afeta a própria relação pesquisador-pesquisado. Entendo assim que a fragilidade da investigação no que se refere à dimensão do trabalho pedagógico de sala de aula pode ser entendida exatamente devido ao fato de que o discurso predominante, aquele que se impunha, que preenchia os corredores, as conversas informais e as atividades pedagógicas institucionalizadas, deslocava, em grande medida, a materialização do currículo do interior da sala de aula para outras que o enfatizavam como aglutinador de ações participativas, democráticas e cidadãs.

Se o currículo escolar está para além de conteúdos, métodos, experiências e objetivos presentes na vida escolar, as relações de gênero, a ocupação dos cargos, a política da diferença e a forma como é problematizado o conhecimento e as relações humanas são fruto de uma luta em que se disputa a validação de determinados discursos, práticas e ações seja para perpetrar as desigualdades étnicas, de gênero e de classe social, seja para desestabilizálas, desconstruí-las e reconfigurá-las.

Procurou-se assim compreender que na dinâmica das relações de poder dentro da escola, não se pode dizer nem que aquelas pessoas procuram, pura e simplesmente, reproduzir as desigualdades, nem que buscam enfrentá-las e desconstruí-las. Isto depende mais das posições que os sujeitos ocupam em determinadas situações, de acordo com os diferentes contextos, do que de uma posição, uma identidade fixa em relação a essas desigualdades.

Movido pelo desafio de tentar cruzar o quadro teórico com os dados empíricos desta pesquisa, procurei, sobretudo nestes três últimos itens, estabelecer algumas conexões entre o pós-moderno e a escola, entre discurso, condição e pensamento pós-modernos e o currículo de uma escola pública municipal paulistana.

Para isto procurei não ignorar o que diziam ambas as dimensões que envolvem este trabalho. Tinha que estar atento ao que dizia o campo, a escola, sem perder de vista quais debates travavam os diferentes matizes do pós-moderno em educação. O lema do "aprender a aprender" - seja como ideologia do capitalismo atual, ou como forma discursiva dominante no cenário pedagógico contemporâneo, tanto pelo marxismo quanto pelo pós-estruturalismo , mostrou-se presente em práticas e discursos de diversos integrantes da escola. Em termos da relação professor-aluno, pôde-se considerar a fragilização do primeiro no papel de transmissor social de conhecimentos fundamentais para a compreensão e transformação social. Por outro 
lado, o lema (super) valoriza o aluno como sujeito da aprendizagem e os procedimentos (método) como "finalidades" didáticas, o que incorre em certo esvaziamento/fragilização da concepção de escola como aquela instituição que deve trabalhar com o conhecimento e que tem no professor a peça chave para a execução dessas finalidades.

Em um segundo momento, procurei refletir sobre como o mundo do trabalho e a cidadania interseccionam com o universo da escola e seu currículo. Analisou-se, assim, os desafios e avanços que esta escola tem conseguido para nela desenvolver e implantar uma cultura mais democrática em sua gestão, dando voz a integrantes socialmente excluídos/marginalizados desse processo de participação. Para isso, reconheceram-se esforços internos da gestão por procurar aproximar a escola da comunidade, vinculando-as através da cultura, do esporte e do saber. Por outro lado, mesmo considerando a escola como pólo aglutinador de práticas democráticas e ações cidadãs, a condição social que se lhe impõe tem produzido novas formas de exclusão social, mesmo quando inclui as camadas pobres. As barreiras sociais impostas às camadas pobres para a mobilidade e ascensão social - pelo emprego, acesso aos bens de consumo e extensão da vida estudantil até a universidade tornam-se ainda maiores à medida que a escola está submetida à lógica neoliberal do Estado Mínimo, à maximização dos resultados com o mínimo de recursos financeiros, à desvalorização do professor, e a uma pedagogia calcada no "aprender a aprender". O que vemos são muitos alunos passando pela escola sem dominar as ferramentas essenciais - como leitura, escrita, interpretação, raciocínio dedutivo-matemático - para compreender, mudar e transformar a sociedade e o universo que os cercam.

No terceiro e último momento, busquei analisar as contribuições da perspectiva pósestruturalista, sobretudo de linha foucaultiana, na compreensão do currículo escolar. Mostrouse, assim, a dinâmica das relações sociais de saber-poder existentes na escola e como elas constituem o próprio caráter do currículo da escola. Procurou-se analisar como e porque determinadas práticas discursivas, tanto em sua dimensão social, pedagógica como organizacional, tomam corpo, se territorializam, se hegemonizam. Para isso, compreendeu-se o currículo como política cultural, como lugar de disputa por determinadas narrativas e no "direito" de se narrar o "outro". Para tanto, foi preciso tocar nas questões étnicas, de gênero, em como professor, aluno, agente escolar, direção, coordenação etc. estão inseridos nestas relações de poder-saber, e como têm procurado evidenciar as práticas reprodutoras de dominação e submetimento de uns pelos outros, e enfrentar e alterar esta forma de poder pela da viabilização e ocupação de outras vozes e práticas antes silenciadas e/ou marginalizadas. 
A abordagem dessas questões referentes ao diálogo entre teoria e empiria, guiou-se pela proposição de se situar criticamente em relação ao pós-moderno. Seja relevando os aportes que enfrentam certos estatutos da modernidade e seus efeitos de dominação - como o universalismo e a neutralidade da razão e da ciência, as metanarrativas e a concepção de sujeito do conhecimento autocentrado presentes nas teorias (críticas) educacionais - seja pela necessidade de se apontar o risco de adesão aos ideais neoliberais do capitalismo atual através de práticas pedagógicas e políticas educacionais, o objetivo deste estudo foi refletir sobre possíveis interconexões e relações a respeito da teoria e prática educacional com o pósmoderno quando se debruça sobre a escola e o currículo na atualidade. 


\section{Considerações finais}

Após este longo percurso muita coisa se transforma. O texto, o campo, as idéias, o autor, todos são postos sob o jugo do tempo e de mudanças que ocorrem enquanto se percorre o árduo caminho de produzir um trabalho acadêmico desta modalidade.

Foi preciso ler e reler as idéias que envolviam este trabalho, duvidar de certas crenças, de certas verdades que se impunham de forma sutil, quase que já incorporadas acriticamente. Foi preciso distanciar-se de si, ser estrangeiro no próprio território. Coube refutar certas teses, recuperá-las, revê-las sob outro prisma, afastar-se e lutar; continuar a luta intelectual para entender o mundo enquanto se quer entender a si mesmo, compreender os fenômenos vistos/vividos na escola enquanto se faz a identidade do próprio autor/pesquisador. Fazer um trabalho desta natureza é um mergulho para dentro de si, é uma experiência que faz descobrir quem somos, o que pensamos, no que acreditamos e o que queremos. Foucault (1998:13) tem uma bela passagem quando reflete sobre o ato de filosofar:

De que valeria a obstinação do saber se ele assegurasse apenas a aquisição dos conhecimentos e não, de certa maneira, e tanto quanto possível, o descaminho daquele que conhece? Existem momentos na vida onde a questão de saber se se pode pensar diferentemente do que se pensa, e perceber diferentemente do que se vê, é indispensável para continuar a olhar ou a refletir.(...) Mas o que é filosofar hoje em dia - quero dizer, a atividade filosófica - senão o trabalho crítico do pensamento sobre o próprio pensamento? Se não consistir em tentar saber de que maneira e até onde seria possível pensar diferentemente em vez de legitimar o que já se sabe? Existe sempre algo de irrisório no discurso filosófico quando ele quer, do exterior, fazer a lei para os outros, dizer-lhes onde está sua verdade e de que maneira encontrá-la, ou quando pretende demonstrar-se por positividade ingênua; mas é seu direito explorar o que pode ser mudado, no seu próprio pensamento, através do exercício de um saber que lhe é estranho.

Atravessar este complexo e movediço campo da pós-modernidade, do pensamento pós-moderno na atualidade, revelou-se muito mais complexo, tortuoso e desafiante do que eu imaginava antes de me aventurar por essas veredas. O outro percurso, o empírico, a escola e seus integrantes, sua vida e cotidiano trouxe ardores e esperanças, estímulos e desencantos diante da situação educacional pública contemporânea.

A imagem, a impressão, a experiência que tive naquela escola ao longo de mais de um ano e meio foram de que o macro e o micro social não se dissociam, escola e condição social 
estão interligadas, indivíduos e idéias sobrevivem porque o(as) outro(as) existe(m). A escola, seu PPP e seu currículo mudam, mudam para serem o mesmo, mudam para serem diferentes do que eram. Como procurei mostrar, pois assim o entendi, assim me convenceram, essa escola mudou muito, tornou-se muito diferente do que era e do que são muitos de seus pares. Com isso não quero afirmar que seja um exemplo a ser seguido, um modelo a ser reproduzido nas outras instituições. Mas sim que com ela pode-se aprender a ser diferente em muitas ações, relações e experiências. Pode-se aprender também que seu caminho esta cheio de contraditoriedades, conflitos, harmonias, dissensos e consensos. Que não existe apenas uma voz, uma força, mas que também nem todas têm o mesmo tom e o mesmo peso na arena político-pedagógica da instituição. Viu-se assim, que o conflito faz parte das relações, que vozes e ações são negadas e outras assumidas, que certas práticas são valorizadas e exercidas e outras rechaçadas e enfraquecidas. A escola é uma instituição e uma cultura, sedimentada pela regularidade e transformada por meio de trocas e diferenças entre os sujeitos, idéias e práticas. Na concepção de Santos (1999) novamente, a escola é regulação e emancipação dos sujeitos.

O fato de ter trazido para esta investigação uma dimensão empírica, um mundo dinâmico, repleto de sujeitos, idéias, diferenças, semelhanças, histórias e tradições, levou a apreendê-lo não apartado do universo do pensamento, do discurso e da condição social contemporânea. A escola e seu mundo não flutuam acima ou abaixo, aquém ou além do pensamento, do discurso e da condição resultantes das questões políticas, éticas e epistemológicas que nos permeiam como seres sociais. A escola enfrenta, resiste, dialoga, ignora, se relaciona com o mundo que a cerca. Seu currículo vive e sobrevive do que o mundo social "oferece", produz e reproduz. O campo teórico do currículo deve se dedicar a compreender as múltiplas formas de dominação econômica, social e cultural, assim como abrir "frentes curriculares" alternativas a essas formas.

Sobre a articulação entre teoria e prática do currículo, Moreira (2002) afirma que estamos diante da existência, senão de um isolamento, uma distância entre o que se pensa criticamente sobre o campo do currículo e o que dele se realiza, o que se formula em termos de enfrentamento teórico e implantação de políticas e práticas educacionais nas escolas. Entendendo que a prática do professor na escola não é a reprodução/aplicação da teoria produzida pela cultura acadêmica, Moreira (idem:73) aponta para "a necessidade de se pensar a articulação teoria-prática no campo do currículo de modo a facilitar o desenvolvimento da capacidade prática e da experiência teórica do professorado”, ou então, continuaremos a ver apenas os estilhaços do debate teórico da cultura acadêmico-crítica atingindo, quando muito, 
o discurso docente e dos profissionais da escola sem alterar, de fato, as relações de podersaber no interior da instituição e na relação escola-universidade.

Mapear, compreender, interpretar o que é a atualidade, o que vivemos, o que vive a escola pública brasileira de hoje, como se desenvolve seu currículo mobilizaram as inquietações deste trabalho, mesmo sabendo da incomensurabilidade da empreitada. Entretanto, importava o desafio, o percurso, os desencantos, as descobertas. A pósmodernidade e o pensamento pós-moderno não abarcam a "totalidade do real" 35 , não querem, não se propõem ou não conseguem dar conta da contemporaneidade. A pós-modernidade e o pensamento pós-moderno não são a própria contemporaneidade! É preciso colocá-los em outro território, sob outro prisma para se entender as mensagens enviadas, as críticas feitas e as limitações que se lhes impõem.

Como afirmei em linhas anteriores, deve-se ser crítico ao discurso, pensamento e condição pós-modernos por suas ambigüidades e aproximações com os ideais neoliberais em educação, assim como deve-se tomar este pensamento como contributo crítico a certos estatutos da modernidade. Por conta disso, considero ser o pensamento crítico da modernidade muito mais elaborado pelas contestações que formula do que por alternativas que propõe. Sabe ele melhor denunciar as limitações de outras (meta) narrativas, revelando os mecanismos de poder e dominação, as vozes que falam por outras, do que de fato, apresentar a territorialidade de sua voz, o que defende e em que se apóia. Eleger a pós-modernidade sob a condição de pensamento, e mais, apontar que dela não emerge uma teoria ordenada, coerente em bases éticas e epistêmicas, é fruto do que é o mundo global contemporâneo, isto é, um mundo resultante do vitorioso capitalismo que já não "sustenta" mais a utopia socialista como forma alternativa de luta e resistência organizada em nível macro social. O pensamento pós-moderno, nesse sentido, "se rende", ou, ao menos aceita a consolidação efetiva do sistema capitalista como modo de produção e regulação das relações sociais, e procura, assim, pelo menos em sua versão (pós) crítica/pós-estruturalista - ou de resistência, de fronteira, como propõe Giroux (1995) - atacar e atingir o rolo compressor (neo)liberal-capitalista de forma atômica, localizada.

\footnotetext{
35 Inclusive porque a noção de totalidade é senão refutada, deslocada para um posto secundário. Os pósmodernos prefeririam a noção de complexidade.
} 
Para os pós-modernos, o tempo em que vivemos parece não permitir a elaboração teórica - a superestrutura, na compreensão marxiana ${ }^{36}$ - capaz de fazer frente à base material - a infra-estrutura - hegemônica do capitalismo tardio. Por isso, direcionam seus investimentos críticos à analise e ações políticas localizadas que buscam preservar uma política da diferença em um mundo desigual, como no caso dos movimentos sociais defensores de direitos às diferenças - de etnias, da mulher, dos homossexuais, do acesso à terra, à moradia, à universidade, da liberdade de migração, etc.; buscam produzir ataques de explosões limitadas, dada a assimetria entre hegemonia capitalista e a resistência (quase) individual do sujeito contemporâneo; elaboram críticas às antes ignoradas relações entre poder e conhecimento da ciência positivista-burguesa-liberal e suas consequientes formas de dominação e subjugação cultural do "sujeito" sobre seu "objeto"; constróem reflexões teóricas de envergaduras circunscritas mais às dimensões culturais do que às estruturas políticoeconômicas, como é o caso das crescentes investigações de âmbito micro social-cultural e estudos sobre o cotidiano. Isto ajuda a entender por que muitos chamam os teóricos pósmodernos de neoconservadores, na medida em que estes últimos não "enfrentam" o sistema capitalista em sua totalidade e porque deslocam, muitas vezes, questões políticas de exclusão, exploração e dominação para o paradigma da linguagem, do discurso, da textualidade.

Emerge daí uma contradição intrínseca no pensamento pós-moderno em educação. Se, por um lado ele, procura criticar as formas de poder existentes e "relativizar" a supremacia de certos discursos dominantes - de homem, europeu, branco, heterossexual, etc. - por outro, incorre no risco de impedir a crítica de determinadas estruturas sociais consolidadas as quais mantém o status quo educacional desta forma desigual. Silva (1993:135) sintetiza claramente isto, nas palavras a seguir:

...o pós-modernismo pode ser útil para um projeto educacional crítico na
medida em que nos torna conscientes a respeito dos efeitos de verdade de
todos os discursos, mas pode ter também conseqüências regressivas e
conservadoras quando essa desconfiança em relação aos discursos e ao
caráter ilusório de todos os discursos nos impede de fazer uma critica de
estruturas sociais que são bem reais e concretas...

Entretanto, não se pode perder de vista a perspectiva mais realista e menos utópica do pós-estruturalismo em educação em relação ao que muitas vezes as correntes neomarxistas demonstram. A concepção pós-estruturalista não permite se iludir com a idéia de um

${ }^{36}$ Cf. Marx, K. A Ideologia Alemã. São Paulo: Moraes, 1984. 
"projeto" de educação emancipatório do homem, no qual a humanidade se encontrará soberana e acima dos domínios e mazelas do poder e se reconfortará no terreno seguro da verdade através da razão universal. Seu objetivo é exatamente desestabilizar essa confiança utópica, desmontando a base que sustenta a cognoscência do sujeito auto-centrado, a transparência da verdade e a teleologia da história. Enfatizando precisamente as relações de poder-saber através de múltiplas formas discursivas, o pós-estruturalismo sobrevive de seu caráter transgressivo, subversivo e desestabilizador. Em poucas palavras, o pós-estruturalismo em educação procura desinstrumentalizar o sujeito da educação de seus elementos transformadores de caráter emancipatório. Procura, assim, mais desconstruir discursos/projetos educacionais críticos ou não-críticos vigentes do que colocar no lugar outros sob outras bases. Em contrapartida, não se pode ignorar que a prática educativa, institucional ou não, requer fundamentos filosóficos que a sustentem, princípios que balizem a seleção de conteúdos e métodos de ensino, para que não se caia nem em um vale-tudo nem em um niilismo pedagógico.

A encruzilhada com a qual se deparam a educação e as escolas, portanto, pode sintetizar-se na proposição de Goergen (2000:70)

A renegação do universal, do perene e do necessário pode levar tanto ao
caminho positivo do pluralismo intercultural, do reconhecimento das
culturas, tradições, valores, locais, etc., quanto ao relativismo
epistemológico e ético; tanto ao reconhecimento crítico das diferenças
quanto à indiferença política, tão peculiar à sociedade contemporânea que se
acerca do cultural pela utilidade e pelo consumo.

Ao campo teórico-prático do currículo, considero fértil e necessário aprofundar as pesquisas e reflexões levando em consideração os aportes da teoria crítica sem deixar para trás questões postas pelo pensamento pós-moderno/pós-estruturalista no que se refere à evidenciação e ampliação das formas de poder e dominação na educação e na escola. Não são elas (educação e escola) nem só emancipação nem só regulação do indivíduo e da sociedade.

Quando penso nos impactos que este debate tem para um projeto crítico-transformador em educação, entendo ser necessário centrar a análise nos nexos entre educação/escolarização e as estruturas e processos que constróem a desigualdade social e mantêm as formas opressivas de dominação existentes, por um lado, e na elaboração de formas alternativas de currículos, pedagogias e ações educativas que representem a defesa da justiça, da igualdade e liberdade, por outro. Desta forma, não se pode perder de vista, um projeto educacional (pós-) crítico que se preocupe centralmente com o desvelamento das formas, discursivas ou não, de 
poder e dominação e de manutenção das reais condições educacionais e de práticas de ensino por todo este país. 


\section{Referências Bibliográficas}

ALTHUSSER, L. Ideologia e aparelhos ideológicos do Estado. Rio de Janeiro: Graal, 1983. ANDRE, Marli E.D.A de. A contribuição do estudo de caso etnográfico para a reconstrução da didática. São Paulo, FEUSP. Tese de livre docência, 1992.

Etnografia da prática escolar. Campinas: Papirus, 1995.

ARENDT, Hannah. Entre o passado e o futuro. São Paulo: Perspectiva, 1992.

BERMAM, Marshall. Tudo que é sólido desmancha no ar - a aventura da modernidade. São Paulo: Cia. das Letras, 1986.

BOURDIEU, Pierre; PASSERON, Jean-Claude. Reprodução: elementos para uma teoria do sistema de ensino. Rio de Janeiro: Francisco Alves, 1975.

CANARIO, Rui. Os estudos sobre a escola: problemas e perspectivas. In: BARROSO, João. O estudo sobre a escola. Porto: Porto Editora, 1996.

ALVES, Natalia; ROLO, Clara do Nascimento Batista. Escola e exclusão social: para uma análise critica da política Teip. Lisboa: Educa Organizações, 2001.

COSTA, Marisa Vorraber. (Org.). A escola tem futuro? Rio de Janeiro: DP\&A, 2003.

- Currículo e política cultural In: (Org.). O currículo nos limiares do contemporâneo. Rio de Janeiro: DP\&A, 1998.

DE ALBA, Alicia. Posmodernidad y educación. Implicaciones epistémicas y conceptuales en los discursos educativos. In: (Org.). Posmodernidad y Educación. CESU/UNAM. México: Miguel Angel Porna Editor, 1995.

DELLA FONTE, Sandra Soares. Filosofia da educação e 'agenda pós-moderna'. $27^{a}$ Reunião Anped. Caxambu, 2004 (trabalho apresentado no GT de Filosofia da Educação).

DOMINGUES, Isaneide. O trabalho coletivo e a (re)construção da profissionalidade docente. Dissertação de Mestrado, FEUSP, 2004.

DUARTE, Newton. Vigotski e o 'aprender a aprender': crítica às apropriações neoliberais e pós-modernas da teoria vigotskiana. $2^{\mathrm{a}}$ ed. Campinas: Autores Associados, 2001.

FEATHERSTONE, Mike. Cultura de consumo e pós-modernismo. São Paulo: Studio Nobel, 1995.

FERNANDES, Heloisa Rodrigues. Infância e modernidade: doença do olhar. In: GHIRALDELLI JR., Paulo. (Org.). Infância, escola e modernidade. São Paulo: Cortez, 1996. FOUCAULT, Michel. O que é Iluminismo? In: Dits et Écrits. vol. IV. Paris: Gallimard, 1994 (texto traduzido, s/d, mimeo).

A ordem do discurso. São Paulo: Loyola, 1996. 
História da sexualidade II - o uso dos prazeres. Rio de Janeiro: Graal, 1998. Vigiar e punir: nascimento da prisão. 22a ed. Petrópolis: Vozes, 2000.

FRIDMAN, Luis Carlos. Vertigens pós-modernas: configurações institucionais contemporâneas. Rio de Janeiro: Relume Dumara, 2000.

GADOTTI, Moacir. Projeto político-pedagógico da escola: fundamentos para sua realização. In: GADOTTI, M.; ROMÃO, J.E. (Orgs.). Autonomia da escola: princípios e propostas. $3^{\mathrm{a}}$ ed. São Paulo, 2000. (Guia da escola cidadã, v.1).

Pressupostos do projeto pedagógico. In: O projeto pedagógico na escola. Série Atualidades pedagógicas no. 9. MEC/FNUAP,1994.

GAGNEBIN, Jeanne Marie. Infância e pensamento. In: GHIRALDELLI JR., Paulo. (Org). Infância, escola e modernidade. São Paulo: Cortez, 1996.

GIDDENS, Anthony. As conseqüências da modernidade. São Paulo: UNESP, 1991.

GIROUX, Henry A. O pós-modernismo e o discurso da crítica educacional. In: SILVA, Tomaz Tadeu da. Teoria educacional crítica em tempos pós-modernos. Porto Alegre: ARTMED, 1993.

La pedagogía de frontera en la era del posmodernismo. In: DE ALBA, Alicia. (Org.). Posmodernidad y Educación. CESU/UNAM.México: Miguel Angel Porna Editor, 1995.

Jovens, diferenças e educação pós-moderna. In. CASTELLS, Manuel et al. Novas perspectivas críticas em educação. Porto Alegre: Artes Médicas, 1996.

GIROUX, Henry A.; McLAREN, Peter. Por uma pedagogia crítica da representação. In: SILVA, Tomaz Tadeu da; MOREIRA, Antonio Flávio. Territórios contestados - o currículo e os novos mapas políticos e culturais. $6^{\text {a }}$ ed. Petrópolis: Vozes, 2004.

GOERGEN, Pedro. Pós-modernidade, ética e educação. Campinas: Autores Associados, 2001. (Coleção polêmicas do nosso tempo; 79).

HABERMAS, Jurgen. Pensamento pós metafísico: estudos filosóficos. Rio de Janeiro: Tempo Brasileiro, 1990.

HARVEY, David. Condição pós-moderna. $8^{\mathrm{a}}$ ed. São Paulo: Loyola, 1999.

HOBSBAWN, Eric. Era dos extremos: o breve século XX - 1914-1991. São Paulo: Cia. das Letras, $2^{\mathrm{a}}$ ed., 2003.

IMBERNÓN, F. (Org.). La educación en el siglo XXI. Los retos del futuro inmediato. $4^{\mathrm{a}}$ ed. Barcelona: Ed. Graó, 2002.

JAMESON, Frederic. Pós-modernismo e sociedade do consumo. In: Novos Estudos do CEBRAP, São Paulo, Número 12, Jun-1985. Pós-modernismo - a lógica cultural do capitalismo tardio. São Paulo: Ática, 1996. 
KANT, Immanuel. Resposta à pergunta: o que é Iluminismo. In: A paz perpétua e outros opúsculos. Lisboa: Edições 70, 1989.

. Sobre a pedagogia. Piracicaba: Unimep, 1999.

LIBÂNEO, José Carlos. Pedagogia e modernidade: presente e futuro da escola. In: GHIRALDELLI JR., Paulo. (Org.). Infância, escola e modernidade. São Paulo: Cortez, 1996. LYOTARD, Jean F. O pós-moderno. Rio de Janeiro: José Olimpio, 1986.

O pós-moderno explicado para crianças: correspondências 1982-1985. $2^{\mathrm{a}}$ ed. Lisboa: Dom Quixote, 1993.

LUDKE, Menga; ANDRÉ, Marli E.D.A. Pesquisa em educação: abordagens qualitativas. São Paulo: EPU, 1986.

MARCELINO, Márcio M. A evolução urbana do Parque Peruche e sua gente. São Paulo: Carthago, 2003.

MCLAREN, Peter. Pós-modernismo, pós-colonialismo e pedagogia. In: SILVA, Tomaz Tadeu da. Teoria educacional crítica em tempos pós-modernos. Porto Alegre: ARTMED, 1993.

MOREIRA, Antonio Flávio Barbosa; SILVA, Tomaz Tadeu da. Sociologia e teoria crítica do currículo: uma introdução. In: (orgs.). Currículo, cultura e sociedade. São Paulo: Cortez, 1994.

(Org.). Currículo: questões atuais. Campinas: Papirus, 1997.

MOREIRA, Antonio Flávio Barbosa. A crise da teoria curricular crítica. In: COSTA, Marisa Vorraber; MOREIRA, Antonio Flávio Barbosa et al. (Orgs.). O currículo nos limiares do contemporâneo. Rio de Janeiro: DP\&A, 1998.

O campo do currículo no Brasil: os anos noventa. In: CANDAU, Vera Maria. (Org.). Didática, currículo e saberes escolares. Rio de Janeiro, DP\&A, $2^{\text {a }}$ ed. 2002.

NASSIF, R.; RAMA, G.W.; TEDESCO, J.C. El sistema educativo en América Latina. Buenos Aires: Kapelusz, 1984.

NÓVOA, António. Os professores na virada do milênio: do excesso dos discursos à pobreza das práticas. Revista da Faculdade de Educação da USP, v. 25, n.1, p.11-20, 1999.

OLIVEIRA-FORMOSINHO, Júlia. Um capítulo metodológico: os estudos de caso. In: OLIVEIRA-FORMOSINHO, Júlia; KISHIMOTO, Tisuko Morchida. (Orgs.). Formação em contexto: uma estratégia de integração. São Paulo: Pioneira Thomson Learning, 2002.

OSCARIS, Roberto R. Hernández; JIMENEZ, Elsa Vega. Historia de la educación latinoamericana. Habana: Pueblo y Educación, 1995. 
PÉREZ GOMEZ, A. I. A cultura escolar na sociedade neoliberal. Porto Alegre: ARTMED, 2001.

ROUANET, P. S. As razões do Iluminismo. São Paulo: Cia. das Letras, 2000.

ROUANET, P. S.; MAFESSOLI, M. Moderno x Pós-Moderno. Rio de Janeiro: UERJ, 1994.

SACRISTÁN, J. Gimeno. Poderes instáveis em educação. Porto Alegre: Artmed, 1999.

SANTOS, Boaventura de Sousa. Pela mão de Alice: o social e político na pós-modernidade. $5^{\text {a }}$ ed. São Paulo: Cortez, 1999.

SAVIANI, Dermeval. Escola e democracia: teorias da educação, curvatura da vara e onze teses sobre educação e política. $31^{\text {a }}$ ed. Campinas: Autores Associados, 1997a.

Pedagogia histórico crítica: primeiras aproximações. $6^{\mathrm{a}}$ ed. Campinas: Autores Associados, 1997b.

SEVERINO, Antônio Joaquim. O diretor e o cotidiano na escola. Idéias 12. São Paulo: FDE, 1992.

. Metodologia do trabalho científico. $21^{\mathrm{a}}$ ed. São Paulo: Cortez, 2000.

O projeto político-pedagógico: a saída para a escola. Revista de Educação AEC Para onde vai a escola? Brasília. AEC. V. 27, no. 107, 1998.

SILVA, Tomaz Tadeu da. Sociologia da educação e pedagogia crítica em tempos pósmodernos. In: Teoria educacional crítica em tempos pós-modernos. Porto Alegre: ARTMED, 1993.

(Org.). O sujeito da educação: estudos foucaultianos. $2^{\text {a }}$ ed. Petrópolis: Vozes, 1995.

Documentos de identidade: uma introdução às teorias do currículo. Belo Horizonte: Autêntica, 1999a.

- Educação, trabalho e currículo na era do pós-trabalho e da pós-política. In: FERRETTI, J. Celso; SILVA JR, João dos Reis; OLIVEIRA, Maria Rita N. S. (Orgs.). Trabalho, formação e currículo. São Paulo: Xamã, 1999b.

SMART, Barry. A pós-modernidade. Portugal: Europa-América, 1993.

SOUSA, J.V. de. A identidade do sujeito social, ético e político e o projeto políticopedagógico da escola. In: VEIGA, I.P.A.; FONSECA M. (Orgs.). As dimensões do projeto político-pedagógico: novos desafios para a escola. $1^{\mathrm{a}}$ ed. Campinas: Papirus, 2001a.

VEIGA, Ilma P. A. Projeto político-pedagógico da escola: uma construção coletiva. In: . (Org.). Projeto político-pedagógico da escola: uma construção possível. Campinas:

Papirus, 2001b. 
Projeto político-pedagógico: novas trilhas para a escola. In: VEIGA, I. P. A e FONSECA, M. (Orgs.). As dimensões do projeto político-pedagógico: novos desafios para a escola. $1^{\text {a }}$ ed. Campinas: Papirus, 2001a.

VEIGA-NETO, Alfredo. Pensar a escola como uma instituição que pelo menos garanta a manutenção das conquistas fundamentais da Modernidade. In: COSTA, Marisa Vorraber. (Org.). A escola tem futuro? Rio de Janeiro: DP\&A, 2003.

WEBER, Max. Ciência e política: duas vocações. São Paulo: Cultrix, 1967.

Economia e sociedade: fundamentos da sociologia compreensiva. Brasília: UNB, 1991.

YAGUEZ, Jorge Alvarez. Individuo, libertad y comunidad - liberalismo y republicanismo: dos modos de entender la ciudadania. Madrid: Ludus, 2000. 


\section{Anexo - Roteiro das entrevistas (semi-estruturada)}

1. Você como, busca realizar o quê? Quais são seus principais desafios, facilidades e empecilhos de trabalho?

2. Quais são os objetivos e propósitos da escola acordados no PPP deste ano?

3. É possível colocá-los em prática? O que dificulta esta execução?

4. O que você entende ser o papel da escola contemporaneamente? Para que ela deveria servir? Este papel está muito longe do que ela realiza?

5. A escola mudou muito nos últimos tempos? O Garcia mudou? Eleja o que você considera ter se mantido e o que, de fato, mudou? O que precisa para mudar nos tópicos antes apontados? (mudou o perfil dos alunos, professores, funcionários e comunidade, o tipo de trabalho didático, etc.)

6. O que é preciso assegurar para que a escola exerça seu papel e sua função na sociedade?

7. Qual o elemento organizador da proposta da escola? O que dá "liga" ao trabalho na escola?

8. Qual é a importância do conhecimento para a definição dos rumos e diretrizes da escola?

9. O que é relevante ensinar?

10. O que realmente se aprende na escola em sua opinião?

11. Você acha que mudou o que se ensina na escola? O que mudou?

12. Você acha que mudou para quem se ensina na escola? O que mudou?

13. Como é o dia-a-dia desta escola a partir da sua atividade aqui dentro?

14. Como é a relação da escola com a comunidade do ponto de vista?

15. Como você vê o Garcia em relação às outras escolas (públicas / privadas, de outras regiões, onde trabalhou)? O que se assemelha e o que se diferencia? 